CONSELHO NACIONAL DE DESENVOLVIMENTO CIENTIFICO E TECNOLOGICO (CNPq.) INSTITUTO NACIONAL DE PESQUISAS DA AMAZONIA (INPA)

\title{
Revisão Taxonômica
}

\section{das Rutaceae do Estado do Amazonas}

Byron W. P. de Albuquerque INPA - Manaus

ACTA AMAZÔNICA vol. 6 (3): Suplemento 


\section{ALBUQUERQUE, Byron W. P. d $\rightarrow$}

Revisão taxonômica das Rutaceae do Estado do Amazonas. Acta Amazonica, Manaus, 6 (3: Suplemento) set., 1976.

67 . ilust.

1. Rutaceas - Revisão taxonômica. 2. Botânica sistemática. I. Título.

CDD 583.24811

CDU 583.24(811)

RESUMO: Revisẩo taxonômica das Rutaceae do Estado do Amazonas que conta com 16 gêneros $€ 29$ espécies (inclusive 2 variedades), cujas caracteristicas morfológicas externas săo suficientemente distintas para permitir a separaçăo intergenérica $e$ interespecifica dos taxa estudados. Os gêneros que ocorrem na regiăo sấo Adiscanthus, Cusparia, Decagonocorpus, Erythrochiton, Esenbeckia, Galipea, Hortia, Leptothyrsa, Monnieria, Myllanthus, Nycticalanthus, Raputia, Ravenia, Spathelia, Tícorca e Zanthoxylum. Como auxilio à classificaçấo dos gêneros e das espécies das Rutaceas do Estado do Amazonas sắo apresentadas oito chaves analíticas baseadas nos caracteres morfológicos das plantas estudadas. Ilustram o trabalho 40 fotografios das 29 espécies dos 16 gêneros e 16 figuras mostrando a distribuição geográfica dos taxa estudados. 
CONTEÚDO

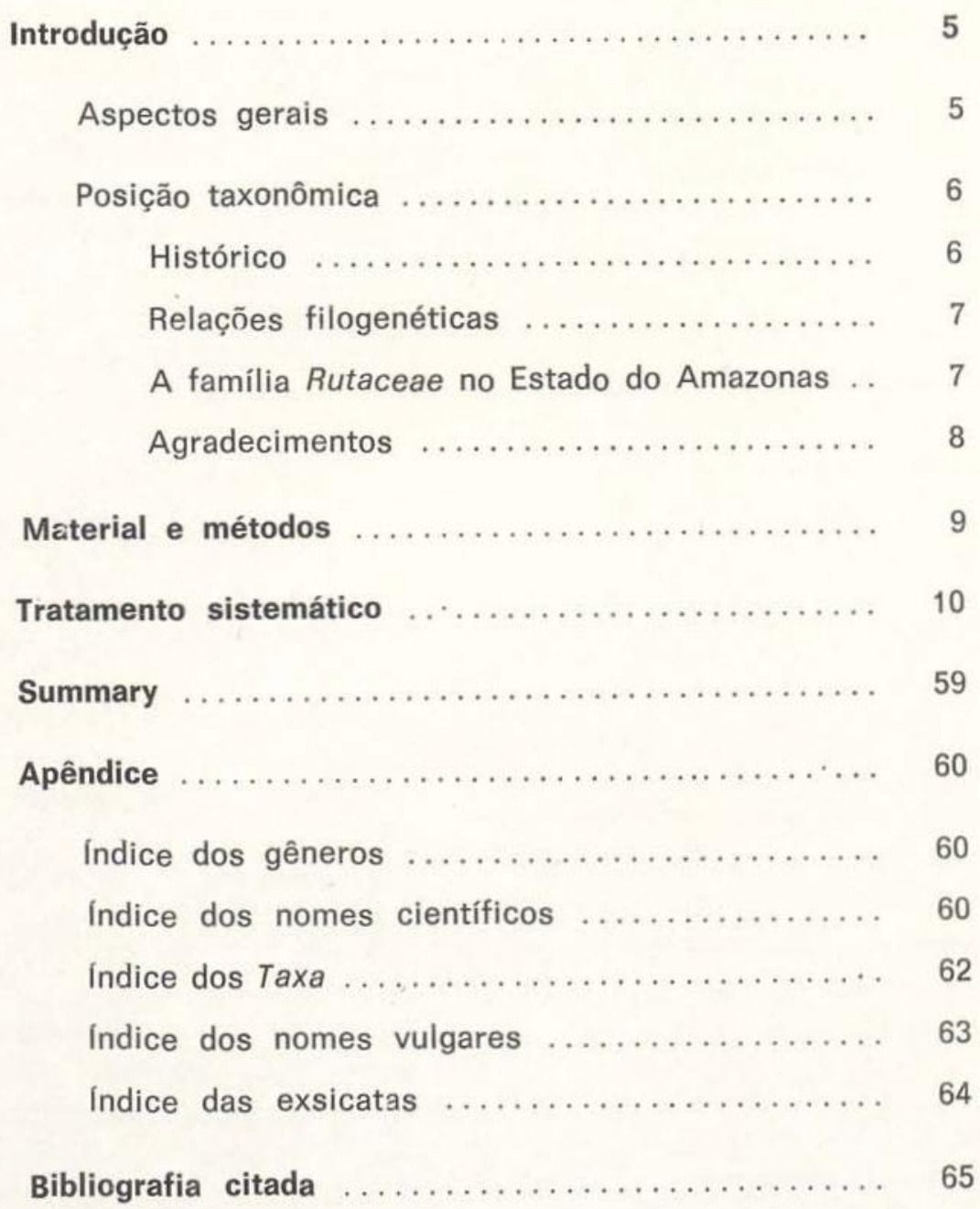




\section{ASPECTOS GERAIS}

As Rutaceae são largamente distribuídas pelas regiões dos trópicos úmidos e temperadas do mundo, reunindo cerca de 1612 espécies. Para o Brasil estão assinaladas aproximadamente 188 espécies, das quais cerca de 56 ocorrem na Amazònia.

Esta família se distingue das outras de seu grupo por apresentar freqüentemente glândulas translúcidas nas folhas. Outra característica importante das Rutaceae é o desenvolvimento de glândulas produtoras de óleo tortemente aromático, cujo papel ecológico, segundo Haberlandt (1928), é provavelmente de protegê-las contra a ação de predadores.

Nossa curiosidade sobre as Rutaceae surgiu devido a sua confusa taxonomia, visto que o número de taxa cresceu desordenadamente com inúmeros trabalhos, descrições de novos gêneros e espécies, em literatura dispersa não havendo monografia da família desde Engler (1896 e 1931). Para a Amazônia, onde a família é bem representada com cerca de 56 espécies, apenas uma monografia de Albuquerque (1970) sobre o gênero Fagara L. era conhecida. Atualmente, o gênero Fagara é considerado como sinônimo de Zanthoxylum L. por Brizicky (1962), Hartley (1966) e Waterman (1975).

A família no Estado do Amazonas conta com 16 gêneros e 29 espécies distribuídos desde a Amazônia Ocidental fronteiriça à Venezuela, Colômbia e Peru, ao longo da calha amazônica até a Central, que é seu principal centro de distribuição geográfica. Alguns gêneros têm poucos representantes ou ainda são representados apenas por uma espécie como Adiscanthus, Erythrochiton, Esenbeckia, Leptothyrsa, Monnieria, Nycticalanthus, Raputia, Spathelia e Ticorea. Possivelmente, o gênero Nycticalanthus ( $N$. speciosus) é endêmico da região de Manaus, na Amazônia Central, pois até o momento não vimos material herborizado ou mesmo referências sobre a ocorrência do referido gênero fora desta área, fato que será comprovado com estudios posteriores. Em contraposição, as espécies Erythrochiton brasiliensis, Monnieria trifolia e Zanthoxylum rhoifolium são as que atingem os limites mais amplos de dispersão no Continente Americano (entre os meridianos $30^{\circ} \mathrm{L}$ e $80^{\circ} \mathrm{O}$, e do paralelo $30^{\circ} \mathrm{S}$ até além do paralelo $20^{\circ} \mathrm{N}$ ) .

As madeiras das Rutaceae são utilizadas para diversos fins econômicos, evidenciandose a da espécie Euxylophora paraensis ("pau amarelo"), que é empregada na indústria madeireira principalmente para tacos, segundo Loureiro \& Silva (1968). Outra espécie de importância para indústria papeleira é Zanthoxylum rhoifolium ("tamanqueira da terra firme"), segundo LeCointe (1947), cuja madeira fornece um rendimento em celulose da ordem de $45,1 \%$.

A família tem vários representantes de valor medicinal, merecendo destaque os "jaborandís" (Pilocarpus jaborandi, P. pauciflorus, $P$. pinnatifolius e $P$. selloanus), que fornecem - alcalóide pilocarpina, muito conheciao no mercado de drogas. Outro representante é a "arruda" (Ruta graveolens) com princípio ativo antiespasmódico, a rutina, que, segundo LeCointe (1947), é irritadora do tubo digestivo e perigosa, podendo causar acidentes letais.

As Rutaceae têm um papel importante na ecologia da vegetação da região amazônica, onde suas espécies vivem nos mais variados tipos de habitat, comc: matas primária e secundária de terra firme, campinas, campinaranas, savanas, várzeas, igapós, margens cie lagos e igarapés, encostas de elevações, pastos secos, margens de estradas e em clareiras de agricultura, conforme podemos verificar na parte referente à distribuição, no final da descrição de cada espécie. 


\section{POSIÇÃO TAXONÔMICA}

\section{HISTÓRICO}

Desde o início as Rutaceae constituiram uma família bastante confusa e dividida. Antigos botânicos como Jussieu (1789), Brown (1814), Candolle $(1822,1824$ e 1825), Nees \& Martius (1823), Kunth (1824), Jussieu (1825), Saint-Hilaire (1825), Bartling (1830), Endlicher (1840) e Lindley (1853), trataram diversas das tribos das Rutaceae atuais como "ordens" separadas, equivalentes à moderna categoria de família. Os gêneros dessas famílias (ordens) e outros gêneros foram gradativamente unidos por taxonomistas como Bentham \& Hooker (1867), Baillon (1873) e Engler (1874).

Bentham \& Hooker (1867) colocaram a família Rutaceae na ordem Geraniales (série II - Disciflorae), junto com as Olacales, $\mathrm{Ce}$ lastrales e Sapindales.

Em seus sistemas de classificação, baseados na filogenia das plantas, Engler (1896) e Bessey (1915) conservaram as Rutaceae incluidas na ordem Geraniales.

No sistema de Hallier (1905), as Rutaceae foram colocadas no grupo das Terebinthinae, juntamente com as famílias Cneoraceae, Meliaceae, Simarubaceae, Terebinthaceae, Aceraceae, Amentaceae e Urticaceae.

Pulle apud Lawrence (1971) dividiu a ordem Terebinthales nas ordens Malpighiales, Polygalales, Sapindales, Balsaminales e Rutales, colocando-as junto com as Pandales, Malvales, Geraniales e Rhamnales na sexta série das Dicotiledôneas de seu sistema de classificação, sendo todas derivadas da ordem Rosales.

Melchior (1964) colocou a família Rutaceae na ordem Rutales (Terebinthales pr. p.), acrescida das Burseraceae, Simarubaceae, Malpighiaceae, Trigoniaceae, Vochysiaceae, Meliaceae e Polygalaceae.

Atualmente, foram propostos os três maiores sistemas filogenéticos de classificação dos vegetais :

- Hutchinson (1973) viu as Rutaceae como a maís dominante família das Rutales no seu sistema de classificação, uma ordem de apenas quatro famílias, incluindo as Bur- seraceae, Simarubaceae e Averrhoaceae. O referido autor diz que as Rutales estão intimamente relacionadas com as Meliales e Sapindales pelas folhas freqüentemente pinadas e raro palmadas; sua origem e afinidade primitivas não estão bem esclarecidas; que as Rutaies seguem evolutivamente após as $\mathrm{Ce}$ lastrales, com um disco floral bem marcante entre o androceu e o gineceu, na ordem filogenética seguinte: Magnoliales - Dillenrales - Bixales - Theales - Celastrales - Rutales.

- Cronquist (1968) e Takhtajan (1969), em seus respectivos sistemas de classiticação, trataram as Rutaceae diferentemente. Cronquist submeteu as ordens Rutales e Meliales sob as Sapindales, colocando nesta última as familias Aceraceae, Anacardiaceae, Burseraceae, Cneoraceae, Hippocastanaceae, Julianaceae, Meliaceae, Rutaceae, Sapindaceae e Simarubaceae, devido a grande afinidade entre si e parecerem bem estabelecidas nessa ordem. Outras famílias de posição incerta nas Sapindales são: Akaniaceae, Connaraceue, Greyiaceae, Melianthaceae, Staphyleaceae e Zygophyllaceae. Cronquist também viu as Rutaceae como a mais dominante familia da ordem Sapindales.

- Takhtajan (1969) tratou as Rutales separadas das Sapindales, em que a primeira ordem ficou constituída das famílias Anacardiaceae. Burseraceae, Cneoraceae, Julianaceae, Meliaceae, Podoaceae, Rutaceae e Simarubaceae, inclusive com algumas famílias de posição incerta como Aitoniaceae, Coriariaceae, Kirkiaceae e Stylobasiaceae. O mesmo autor salienta que, provavelmente, as Rutaceae derivaram das Saxitragales e as Sapindales foram originadas de indivíduos mais primitivos das Rutales ou talvez tenham origem comum com elas, a partir das Saxifragales É ainda o autor que acrescenta serem as Geraniales nitidamente relacionadas com as Rutales, principalmente as Rutaceae.

Do ponto de vista filogenético e taxonômico, concordamos com Cronquist (1968) em ter incluído a família Rutaceae na ordem Sadindales, juntamente com as Aceraceae, Anacardiaceae, Burseraceae, Cneoraceae, Hippocastanaceae, Julianaceae, Meliaceae, Sapin- 
daceae e Simarubaceae, principalmente quando salienta que, além das semelhanças nas características morfológicas clássicas, essas famílias têm muito em comum anatomicamente, conforme demonstrado pelos estudos de Heimsch apud Cronquist (1968).

De acordo com o sistema de classificação de Cronquist (1968), baseado na evolução das plantas, temos :
Classe MAGNOLIATAE (Dicotiledôneas) $\longrightarrow$ Subclasse ROSIDAE $\longrightarrow$ Ordem ROSALES $\rightarrow$ Ordem SAPINDALES $\longrightarrow$ Familia RUTACEAE.

\section{RELAÇÕES FILOGENÉTICAS}

Possivelmente, as Sapindales, segundo Cronquist (1968), estão relacionadas filogeneticamente conforme demonstrado em seguida.

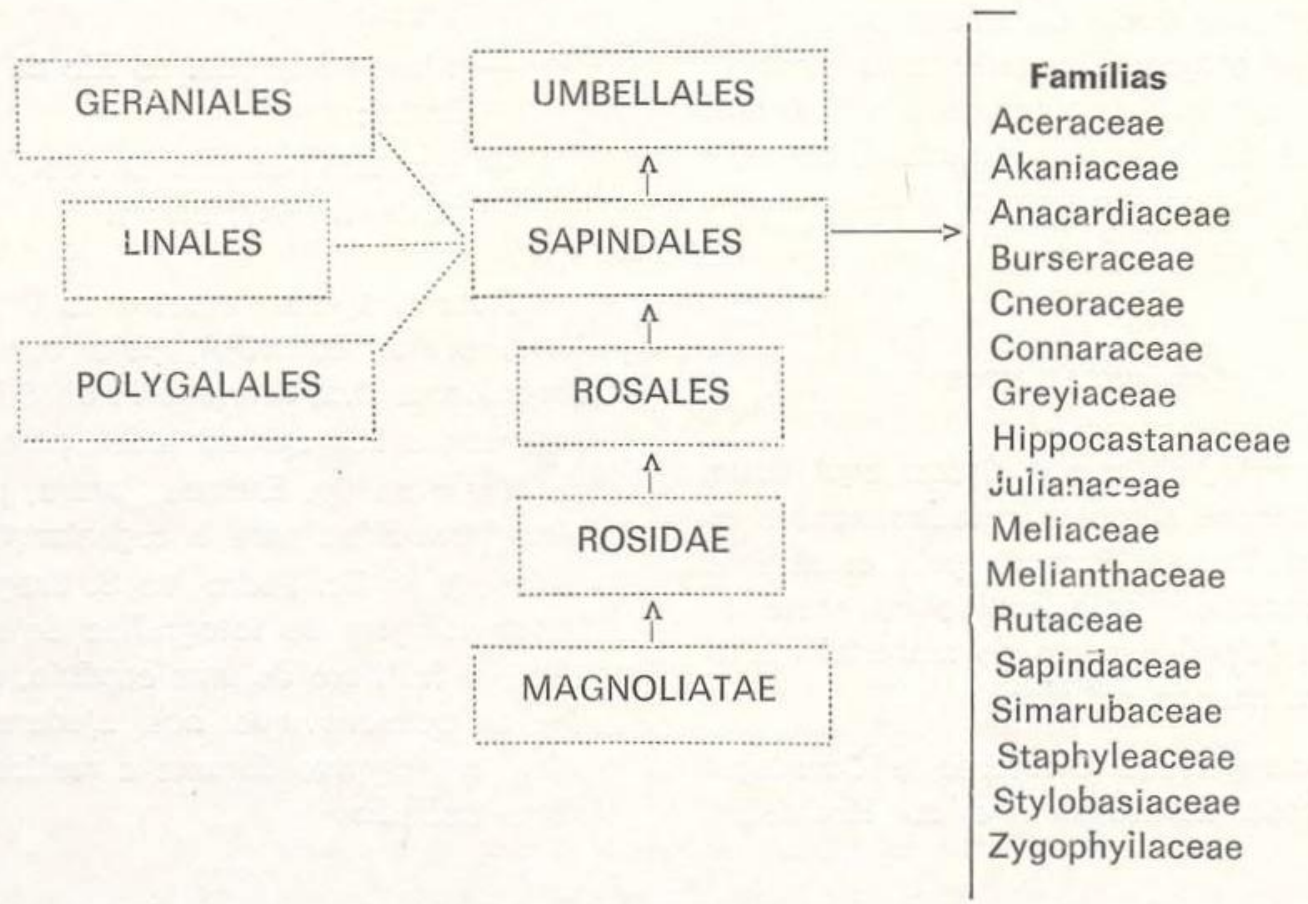

A FAMIÍLIa RUTACEAE NO

ESTADO DO AMAZONAS

De acordo com Engler (1896 e 1931), esta família foi classificada em 7 subfamílias com 10 tribos e 25 subtribos.

No Amazonas, as Rutaceae estão representadas por 3 subfamílias com 3 tribos e 4 subtribos, e um total de 16 gêneros e 29 espécies.

Com base no sistema de classificaçẳo de Engler (1896 e 1931), as Rutaceae do Estado do Amazonas estão assim classificadas :

Família Rutaceae Subfamília Rutoideae

Tribo Zanthoxyleae Subtribo Euzanthoxyliinae
Gêneros :

1 Zanthoxylum L.

$$
\begin{aligned}
& \text { Tribo Cusparieae } \\
& \text { Subtribo Cuspariinae }
\end{aligned}
$$

2 Cusparia Humb.

3 Decagonocarpus Engl.

4 Erythrochiton Nees \& Mart.

5 Galipea Aubl.

6 Monnieria Loefl.

7 Myllanthus Cowan

8 Nycticalanthus Ducke

9 Raputia Aubl.

10 Ravenia Vell.

11 Ticorea Aubl.

Subtribo Pilocarpiinae

12 Adiscanthus Ducke

13 Esenbeckia H.B.K.

14 Leptothyrsa Hook. 


\section{Subfamília Toddalioideae \\ Tribo Toddalieae \\ Subtribo Toddaliinae}

15 Hortia Vand.

Subfamília Spathelioideae

16 Spathelia Linn.

Prance (1968) estudando a posição taxonômica do gênero Rhabdodendron Gilg. \& Pilg., que anteriormente pertencia à família Rutaceae, verificou que o mesmo possuia uma combinação de caracteres morfológicos e anatômicos suficientemente distinta para excluí-lo de todas as famílias conhecidas e criou a nova família Rhabdodendraceae Prance.

\section{AgradeCIMENTOS}

Inicialmente, queremos deixar aqui patenteados os nossos sinceros agradecimentos ao Dr. Ghillean Tolmie Prance, pela orientação científica recebida, pelo auxílio na obtenção de material "tipo" e parte do material bibliográfico para nossos estudos.

Agradecemos aos Diretores e Curadores das seguintes Instituições e/ou Herbários, que nos confiaram o material botânico necessário às nossas pesquisas:

- Instituto Agronômico do Norte (IAN), Brasil;

- New York Botanical Garden (NY), New York, U.S.A.;

- Jardim Botânico do Rio de Janeiro (RB), Brasil;

- Museu Paraense Emílio Goeldi (MG), Brasil;

- Museu Nacional do Rio de Janeiro (R). Brasil;

-. Instituto Nacional de Pesquisas da Amazônia (INPA), Brasil.

Nossos agradecimentos ao Dr. Warwick E. Kerr, diretor do INPA, pelo constante apoio recebido; a Dra. Marlene F. da Silva por algumas sugestões apresentadas para a melhoria do texto; ao Dr. Enrique Forero, pelas sugestões fornecidas para a organização do nosso trabalho; ao Dr. Pedro Ivo S. Braga pelo auxilio na tiragem de fotografias de material florífero e frutífero de uma espécie, e ainda a todas as pessoas que nos ajudaram com seu apoio e incentivo durante a realização do presente trabalho. 
MATERIAL E MÉTODOS

Toda coleção examinada das espécies estudadas encontra-se no final de cada descrição.

As abreviações antes de cada nome de autor e após cada citaçăo bibliográfica de gênero e espécie, nome de autor, número de herbário de origem ou de coletor significam :

$$
\begin{aligned}
& \text { ampl. = ampliado } \\
& \text { comb. nov. = combinação nova } \\
& \text { corr. = corrigido } \\
& \text { em. = emendado } \\
& \text { est = estéril } \\
& \mathrm{fl}=\text { flor } \\
& \mathrm{fr}=\text { fruto } \\
& \mathrm{n} \text {. cons. = nome conservado } \\
& \text { n. rej. = nome rejeitado } \\
& \text { n. v. = não visto } \\
& \mathrm{s} / \mathrm{n}=\text { sem número }
\end{aligned}
$$

Como não nos foi possívevl conseguir os "tipos" de algumas espécies, nossa descrição baseou-se na comparação da descrição original da espécie com o material já determinado.

As abreviaturas dos herbários foram citadas de acordo com o Index Herbariorum, Holmgren \& Keuken (1974).

Os dados sobre fenologia e os "nomes vulgares" foram obtıdos das fichas do material herborizado, consultado.

Apresentamos chaves analíticas para a separação dos gêneros e das espécies.

Ilustram o presente trabalho 40 fotografias e 16 figuras. alfabética.

As descrições botânicas obedecem a uma ordem numérico- 


\section{TRATAMENTO SISTEMÁTICO}

RUTACEAE Bentham \& Hooker, Gen. PI. 1:278. 1867 (em.); Baillon, Hist. PI. 4:373-511. 1873; Engler, in Mart. FI. Bras. 12(2) :78-196. 1874; idem, in Engler \& Prantl, die Nartürl. Pflfam. $3(4): 95-201,357.1896$ e 2a ed. 19a:187-359, 458-459. 1931; Lawrence, Taxon. Vasc. PI. $16^{\mathrm{a}}$ ed. 823 p. 1971; Hutchinson, Fam. Flow. pl. $3^{\text {a }}$ ed. 968 p. 1973.

Ervas, arbustos ou árvores. Folhas alternas, opostas, espiraladas, raro subopostas, simples ou compostas pinadas ou digitadas, com pontuações translúcidas. Flores hermafroditas ou unissexuais por aborto, pequenas a grandes, actinomorfas ou mais ou menos zigomorfas, heteroclamídeas, geralmente imbricadas, dispostas em inflorescências variadas. Sépalas 4-6, livres ou concrescidas, freqüentemente soldadas em um cálice cupular ou campanulado. Corola dialipétala ou gamopétala, com 4-6 pétalas basifixas. Androceu geralmente isostêmone; estames 4-7, alternipétalos, inseridos na base ou na margem do disco, às vezes reduzidos a estaminódios, li- vres ou soldados às pétalas, raro unidos entre si na base; anteras de 2 lojas, rimosas, introrsas, às vezes com apêndices basais, conectivo freqüentemente munido de glândula no ápice. Disco cupular, urceolado, anular ou ginoforói. de, localizado entre o gineceu e o androceu. Gineceu freqüentemente com pistilo simples, às vezes os carpelos são levemente unidos pelos lados, apenas na base ou no ápice, em ambos ou com o pistilo composto (Hortia). Ovário profundamente lobado ou não, 4-5-locular, raro 1-3 ou 2-3-locular; placentação apical; óvuios anátropos, 2 por lóculo, superpostos ou colaterais; estiletes do mesmo número dos carpelos, soldados, aparentemente reunidos em um único, mas cada um possuindo um canal estilar contínuo, raro livres; estígma 1. Fruto cápsula, coca ou raro drupáceo; semente com embrião grande, reto ou curvo; endosperma ausente ou quando presente carnoso.

Gênero típico: - Ruta (Tourn.) Linnaeus, Syst. Nat. ed. 1. 1735.

\section{CHAVE PARA A DETERMINAC̣ÃO DOS GENEROS DE RUTACEAE DO AMAZONAS}

1. Pétalas e estames livres.

2. Folhas simples.

3. Folhas espiraladas; ovário com superficie lisa; fruto coca ou drupáceo.

4. Folhas com o ápice bruscamente acuminado, acúmen emarginado; inflorescência em panículas racemosas de tirsos finos, subcilíndricas; flores tetrâmeras; fruto coca conchiforme.

\section{LEPTOTHYRSA (8.)}

4. Folhas com o ápice normalmente acuminado ou retuso; inflorescência em panículas não racemosas, angulosas; flores pentâmeras; fruto coca rombóide-conchiforme ou drupáceo.

5. Panículas longipedunculadas, dıplamente dicótomas ou mais freqüente tricótomas; flores aproximadas; fruto coca rombóide-conchiforme.

ADISCANTHUS (1.)

5. Panículas curtipedunculadas, muito ramificadas, amplas; flores separadas; fruto drupáceo.

HORTIA (7.)

3. Folhas alternas; ovário provido de ntmerosos tubérculos; fruto cápsula lenhosa, tuberculado-muricada ou munida de apófise no dorso de cada carpídio.

ESENBECKIA (5.) 
2. Folhas compostas.

6. Folhas trifolioladas; flores hermafroditas, grandes, $\mathrm{ca}$. de $10 \mathrm{~cm}$ de comprimento; fruto coca rombóide-conchiforme com a extremidade apical terminando em acúmen prolongado. NYCTICALANTHUS (II.)

6. Folhas pinadas, de 2-100 pares de folíolos; flores dióicas ou polígamas, pequenas, ca. de 4-10 mm de comprimento; fruto coca subglobosa ou obovada ou sâmara.

7. Planta freqüentemente armada de acúleos; folhas com 2-17 pares ou mais de folíolos; flores dióicas; coca subglobosa ou obovada; semente pendente fora do lóculo na maturidade.

ZANTHOXYLUM (16.)

7. Planta não armada de acúleos, com aspecto de palmeira; folhas de 10-100 pares de folíolos; flores polígamas; fruto sâmara 2-3-alada.

1. Pétalas e estames concrescidos.

SPATHELIA (14.)

8. Folhas simples.

9. Folhas espiraladas ou decussadas; cálice gamossépalo, subbilabiado; fruto cápsula; semente tuberculado-muricada.

10. Folhas espiraladas com o pecíolo intumescido no ápice formando um joelho; cálice campanulado, vermelho ou colorido; cápsula 5-angulada.

ERYTHROCHITON (4.)

10. Folhas decussadas, com o pecíolo não intumescido; cálice cupular, nem vermelho nem colorido; cápsula 10-angulada.

DECAGONOCARPUS (3.)

9. Folhas opostas ou pseudo-alternas; cálice dialissépalo, com sépalas desiguais, 2 externas maiores que as 3 internas, fortemente imbricadas; fruto coca; semente lisa.

RAVENIA (13.)

8. Folhas compostas ou muito raro unifolioladas

11. Folhas alternas.

12. Inflorescência em panícula.

13. Folíolos com o ápice emarginado; panícula curtipedunculada; fruto cápsula.

GALIPEA (6.)

13. Folíolos com ápice não emarginado; panícula longipedunculada; fruto coca.

TICOREA (15.)

12. Inflorescência em rácemos ou circinos racemosos.

14. Folhas 3 ou 5-7-folioladas; inf́lorescência em rácemos de cimeiras dicótomas; flores pequenas, retas, ca. de $14 \mathrm{~mm}$ de comprimento; fruto coca.

CUSPARIA (2.)

14. Foihas 4-7-folioladas (mais freqüente 5-folioladas); inflorescência grande; dicotomicamente ramificada, em cincinos racemosos; flores grandes, subsigmóides, ca. de $4 \mathrm{~cm}$ de comprimento; fruto cápsula.

RAPUTIA (12.)

11. Folhas opostas.

15. Plantas herbáceas; inflorescência dicasial (com dois rácemos cincinóides e uma flor terminal no ápice do pedúnculo); flores com sépalas desiguais na forma e no tamanho e corola de tubo reto; semente tuberculado-muricada.

MONNIERIA (9.)

15. Plantas arbustivas ou arbóreas; inflorescência unilateralmente racemoso-cincinóide; flores com sépalas iguais na forma e no tamanho e corola de tubo curvo; semente lisa.

MYLLANTHUS (10.) 


\section{DESCRIÇÕES DOS GÊNEROS E DAS ESPÉCIES}

I. Adiscanthus Ducke, Arch. Jard. Bot. Rio de Janeiro 3: 186 - 187. 1922.

Subarbusto a arvoreta até $5 \mathrm{~m}$ de altura, inteiramente glabros. Folhas densas em direção ao ápice dos ramos, simples, espiraladas, muito curtamente pecioladas ou subsésseis, articuladas com o caule; lâmina foliar obovadolanceolada. Inflorescência terminal, do comprimento das folhas ou mais curta, longipedunculada, pedúnculo anguloso, com ramificações apicais curtas, duplamente dicótomas ou mais freqüente tricótomas, angulosas. Flores pardoamareladas passando a vermelho-escuras até roxas por fora e alvas por dentro, dispostas em cincinos curtos, paucifloros, hermafroditas, pentâmeras, actinomorfas; cálice muito pequeno, vermelho escuro quase preto, pentagonal ou muito curtamente 5-dentado; pétalas 5 , oblongo-espatuladas, glabérrimas por fora e barbadas por dentro, levemente concrescidas na base, prefloração valvar; estames 5 , todos férteis, livres, inseridos na base do ginóforo, filetes achatados, anteras linear-oblongas, dorsifixas, conectivo curto; disco reduzido a ginóforo; ovário de comprimento e largura quase iguais, 5-locular, lóculos concrescidos até pouco acima da metade, 2 óvulos por lóculo; estiletes estreitamente unidos em um só, comprimido, estígmas inconspícuos. Fruto 1-5 cocas vermelhas, rombóide-conchiformes, comprimidas, dorso e ventralmente carinadas, monospermas; semente 1, cônico-comprimida, aguda, com testa fina, parda, crustácea.

Gênero monotípico cuja espécie ocorre no Estado do Amazonas.

\section{Espécie típica: A. fusciflorus Ducke.}

DISTRIBUIÇÃo - Amazônia Central, desde a região de Manaus, no Amazonas, até o baixo rio Tapajós (Bela Vista), no Pará.

O gênero Adiscanthus, segundo Ducke (1922), tem afinidade com o gênero Leptothyrsa em muitos caracteres, mas difere dele pelas flores pentâmeras, inflorescências e anteras dispostas diferentemente e disco ginoforóide. Adiscanthus, por outro lado, separa-se dos demais gêneros da família, entre outras características, por apresentar principalmente as in- florescências com ramificaçỏes freqüentemente tricótomas no ápice do pedúnculo bastante alongado e flores aproximadas.

Adiscanthus Fusciflorus Ducke, Arch. Jard. Bot. Rio de Janeiro 3:187. 1922 e 4:103. 1925. Fotos 1 e 2.

Subarbusto a arvoreta, $1,5-5 \mathrm{~m}$ de altura; caule fino, amarelado; ramos mais jovens cor cinza canela. Folhas $35-54,5 \mathrm{~cm}$ de comprimento, $8-12 \mathrm{~cm}$ de largura, espiraladas; pecíolos até quase $1 \mathrm{~cm}$ de comprimento, sésseis nas foilhas menores, de ápice espesso, sulcado por cima e giboso por baixo; lâmina obovado-lanceolada, longa e moderadamente cuneada para a base, acuminada ou às vezes retusa no ápice, margem inteira; nervura mediana espessamen. te proeminente por baixo, nervuras secundárias horizontalmente paralelas, quase indistintas, levemente arqueadas para o ápice e terminando bem próximo à margem. Inflorescên-

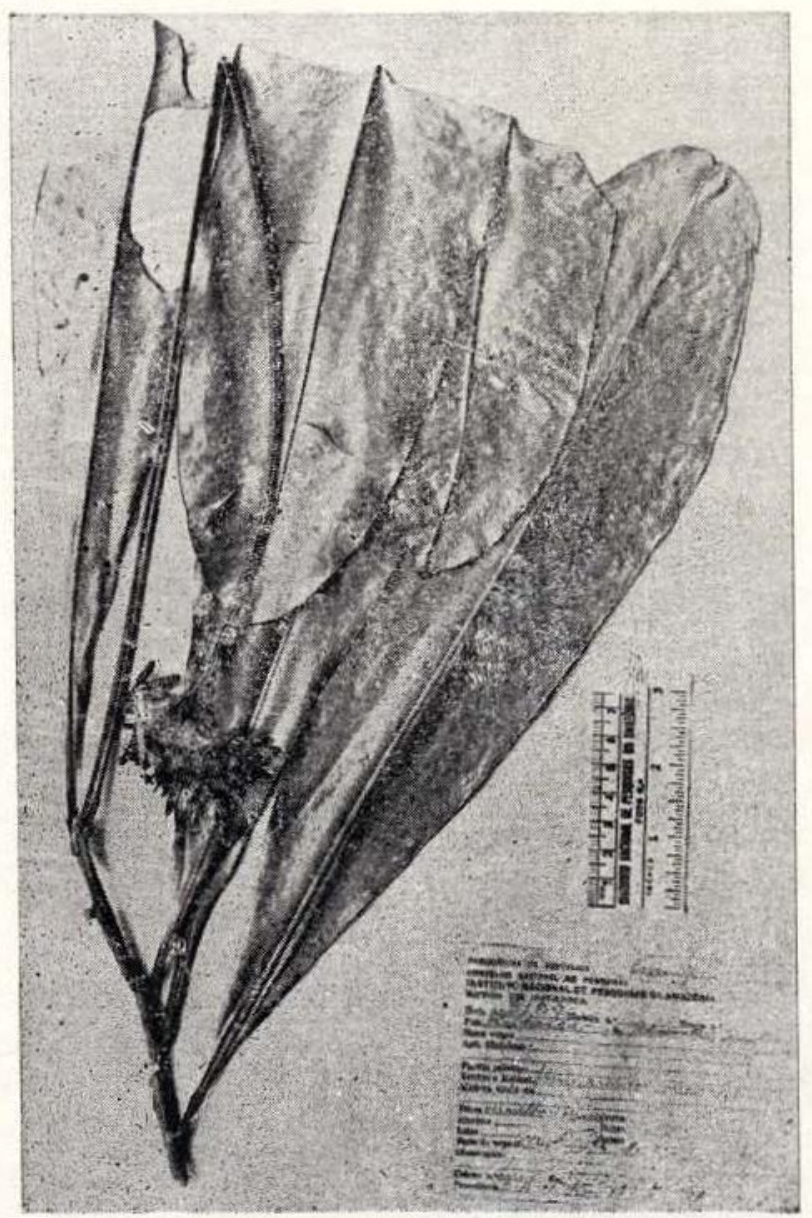

Foto 1. Adiscanthus fusciflorus Ducke. L. Coelho INPA 3109 . 
cia $30-48 \mathrm{~cm}$ de comprimento, com pedúnculo longo, ereto, espesso, anguloso, ca. de $45,5 \mathrm{~cm}$ de comprimento, duplamente dicótoma ou mais freqüente tricótoma no ápice. Flores pardoamareladas passando a vermelho-escuras até roxas por fora e alvas por dentro, muito aproximadas, dispostas em cincinos paucifioros; cálice de pardo a vermelho escuro quase preto; pétalas oblongo-espatuladas, longa e ciensamente alvo ou amareio-barbadas por dentro úcima da metade. Fruto 1-5 cocas vermelhas ou vermelho pardacentas, ca. de $1 \mathrm{~cm}$ de comprimento no diâmetro maior; semente fortemente acuminada; endocarpo amarelo.

TIPo - Ducke $s / n$. Brasil. Pará, rio Tapajós, Bela Vista, fl (holótipo: RB 1295 n. v.).

DISTRIBUição - Amazônia Central, desde Manaus passando por Borba no Amazonas, até Bela Vista no rio Tapajós, Pará, sendo mais abundante no município de Manaus. Habita eni campina, campinarana, matas primária e secundária de terra firme arenosa ou argilosa, úmida, humosa; rara nas margens inundáveis de pequenos igarapés de terra firme. Flores de fevereiro a dezembro e frutos de janeiro a outubro. BRASIL. Amazonas: D. Coelho INPA $2953 \mathrm{fl}$ (INPA); Ducke $62 \mathrm{fl}$ (MG); RB $20473 \mathrm{fl}$ (RB); $R B 23547 \mathrm{fl}$ (RB); L. Coelho INPA 2160 $\mathrm{fl}$ e $\mathrm{fr}$ (INPA, MG 26836); INPA $2223 \mathrm{fl}$ (INPA); INPA $3109 \mathrm{fl}$ (INPA); Ferreira 91-57 fl (INPA); Loureiro et al. INPA $48001 \mathrm{fr}$ (INPA); INPA $48123 \mathrm{fr}$ (INPA); Prance et al. $3181 \mathrm{fl}$ (INPA, $\mathrm{MG}$ ); $4687 \mathrm{fl}$ (INPA); Rodrigues $505 \mathrm{fl}$ e fr (INPA); $8650 \mathrm{fl}$ (INPA); Rodrigues \& Albuquerque $3838 \mathrm{fl}$ (INPA); Rodrigues \& D. Coelho $4144 \mathrm{fr}$ (INPA); $4147 \mathrm{fr}$ (INPA); Rodrigues et al. $1977 \mathrm{fl}$ (INPA). Fig. I.

Adiscanthus fusciflorus é a única espécie até agora descrita para o gênero Adiscanthus.

Ducke (1922) comenta que Adiscanthus fusciflorus lembra Leptothyrsa sprucei peias folhas e pelos frutos, enquanto sua inflorescência tem a forma das inflorescências de de Cusparia trombetensis e Raputia magnifica. A planta é completamente glabra, porém a corola é longamente pilosa por dentru acima da metade e sua côr é freqüentemente velmelho escuro por fora. O caráter mais marcante, no entanto, é a ausência total do disco (reduzido a um ginóforo), o qual apre- senta-se visivelmente desenvolvido em todos os gêneros até aqui conhecidos da tribo Cusparieae.

Segundo informação de material de herbário (!NPA 8350), A. fusciflorus tem o caule e os ramos aromáticos.

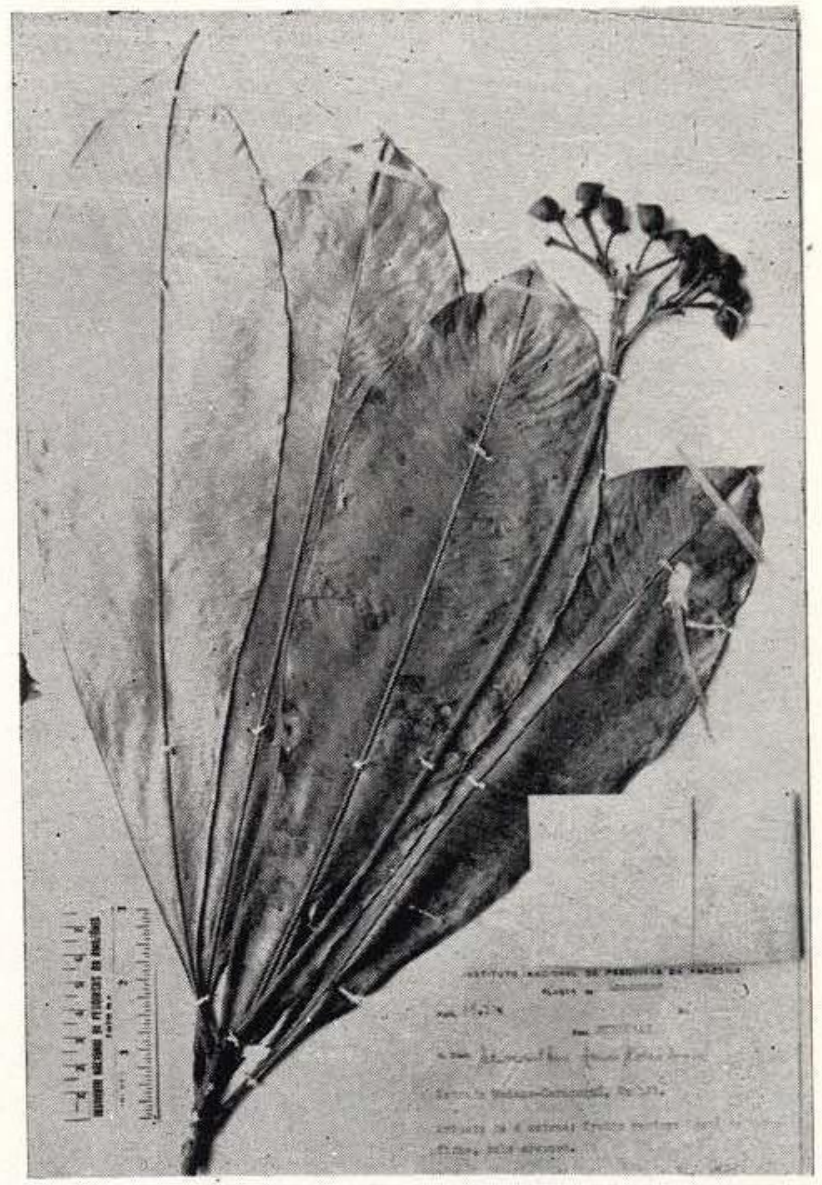

Foto 2. Adiscanthus fusciflorus Ducke. Loureiro et al. INPA 48123 .

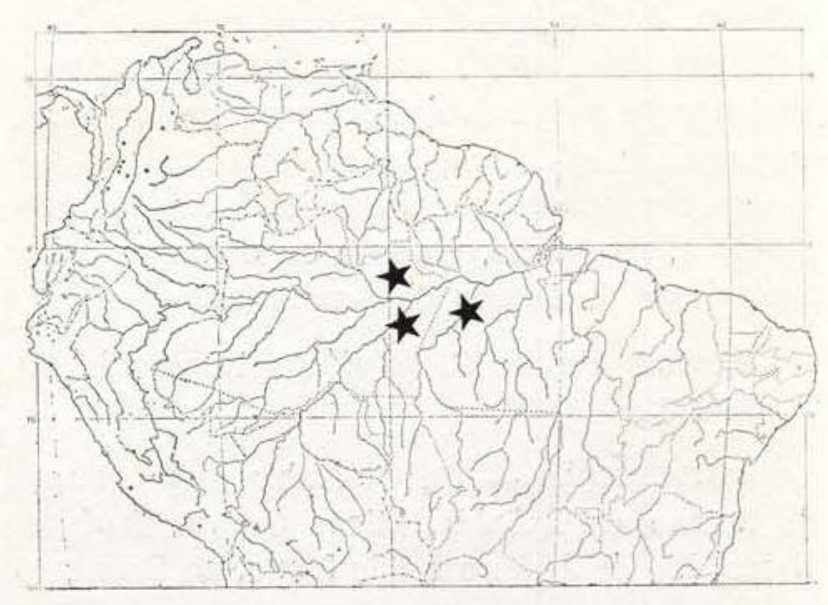

Fig. 1. Distribuição geográfica de $\star$ Adiscanthus fusciflorus. 
2. Cusparia Humboldt, Tabi. Geogr. ex R. Brown, Flinders' Voy. Bot 2, App 3: 345. 1814; Engler, in Mart. FI. Bras. 12(2):108. 1874; Cowan, Sellowia 12: 92. 1960; Albuquerque, An. Acad. brasil. Ci. 40 (4) : 517 1968.

Angostura Roem. \& Schult., Syst. 4: 183. 1819. (*)

Bonplandia Wild., Mem. Acad. Berlin 1802: 24. 1804. (*)

Conchocarpus Mikan, Delect. Fl. \& Faun. Bra sil, fasc. 1, t. 2. 1820 . (')

Dangervilla Vell., F1. Flum. 27. 1825. (*)

Diglottis Nees \& Mart., Nov. Act. Nat. Cur. 11: 151, 170. 1823. (*)

Lasiostemum Nees \& Mart., Nov. Act. Nat. Cur. 11: 162, 171. 1823. (*)

Obentonia Vell., Fl. Flum. 18. 1825. (*)

Rossenia Vell., Fl. Flum. 31. 1925. (*)

Arbustos a arvoretas de $3-6 \mathrm{~m}$ de altura, de caule freqüentemente simples. Folhas alternas, compostas, glabérrimas, aglomeradas no ápice dos ramos. Inflorescência em cimeiras dicótomas de rácemos dísticos ou racemoso-panicuiada, ramiflora ou terminal. Flores alvas ou cremes, hermafroditas, tetrâmeras ou pentâmeras, mais ou menos zigomorfas; cálice cupular, 4-5partido; pétalas linear-oblongas, unidas, em um tubo curto, imbricadas na prefloração; estames $4-5$, com a base e o ápice livres, adnatos às pétalas mais ou menos a altura da metade, 2-3 férteis, filetes achatados, pilosos na face interna, raro na externa, anteras linear-oblongas, conectivo raramente prolongado, estaminódios lanceolado-agudos; disco urceolado ou cupular, 8-plicado ou 5-dentado; ovário 4-5-locular, lóculos unidos apenas pelos estiletes, cada lóculo com 2 óvulos superpostos, estígma pequeno, freqüentemente capitado. Fruto 1-3 cocas obovadas, conchiformes, bivalvas; semente 1, reniforme, globosa ou oblonga.

2 espécies do Estado do Amazonas.

Espécie típica: C. febrifuga Humboldt ex A. P. DC.

DISTRIBUIÇÃo - Da Colômbia e República da Guiana até a Bahia, Minas Gerais, Espírito Santo, Rio de Janeiro e São Paulo, no Brasil.
O gênero Cusparia separa-se dos demais gêneros principalmente pelos estames unidos às pétalas apenas pela região mediana, com a base e o ápice livres.

\section{CHAVE PARA A DETERMINAÇÃo}

DAS ESPÉCIES DE CUSPARIA

1. Folhas 3-folioladas; flores tetrâmeras; esta mes 2 férteis.

\section{1. C. ramiflora}

1. Folhas 5-7-folioladas; flores pentâmeras; es tames 3 férteis.

\section{2. C. toxicaria}

2. 1. Cusparia ramiflora Spruce ex Engler, in Mart. FI. Bras. 12 (2): 111. 1874; Cowan, Mem. N. Y. Bot. Gard. 14 (3): 9. 1967. Foto 3.

Arbustos a arvoretas de $3-4 \mathrm{~m}$ de altura; ramos densamente folhosos para o ápice. FoIhas trifolioladas, membranáceas, folíolos quase iguais, lanceolados, gradativamente atenuados da metade para a base, acuminados no ápice, margem reflexa, $22,5-30 \mathrm{~cm}$ de comprimento e $7-8 \mathrm{~cm}$ de largura. Inflorescência ramiflora, dupla, cada uma em cimeira dicótoma de rácemos dísticos, escorpióides; ramificações até $3 \mathrm{~cm}$ de comprimento com 10-12 flores ou mais. Flores alvas ou cremes, tetrâmeras; cálice sinuoso-4-dentado, lacínios largamente triangulares; pétalas 4 , densamente pubérulas por dentro e por fora, $6 \mathrm{~mm}$ de comprimento, valvares na prefloração, imbricadas apenas no ápice; estames 4, 2 férteis e 2 estéreis, unidos em um tubo curto, filetes densamente barbados, anteras $4 \mathrm{~mm}$ de comprimento; disco urceolado, 8-plicado; ovário agudo, profundamente 4-lobado, sustentado por ginóforo alongado e totalmente envolvido pelo disco, estiletes soldados, profundamente 4sulcados, estígma pequeno. Fruto 1-4 cocas obliquamente obovadas, pequenas, amareladas, finamente crustáceas, densa e curtamente pilosas, 8 - $9 \mathrm{~mm}$ de comprimento; semente 1 . globosa.

(*) - Sinônimos citados por Engler (1874) e Cowan (1967). 
TIPOS - Spruce 2276. Brasil. Amazonas, São Gabriel da Cachoeira (holótipo B, perdido; isótipo: possivelmente em $\mathrm{K}$; foto isótipo: NY).

DISTRIBUição - Sudeste da Colômbia no rio Vaupés e noroeste do Brasil, no alto rio Negro e ao longo do rio Curicuriari, Estado do Amazonas. Habita em savanas e em campinas ao longo de rios. Colhida com flores de maio a janeiro do ano seguinte e com frutos em maio. BRASIL. Amazonas: Ducke RB $23546 \mathrm{fl}$ (RB); L. Coelho $48 \mathrm{fl}$ e fr (INPA); Pires 1117. fl (IAN); Ribeiro $251 \mathrm{fl}$ (IAN). Fig. 2.

Cusparia ramiflora difere de C. toxicaric por apresentar principalmente folhas trifolioladas, inflorescência dupla, cada uma em cimei. ra dicótoma de rácemos dísticos, escorpióides e flores tetrâmeras.

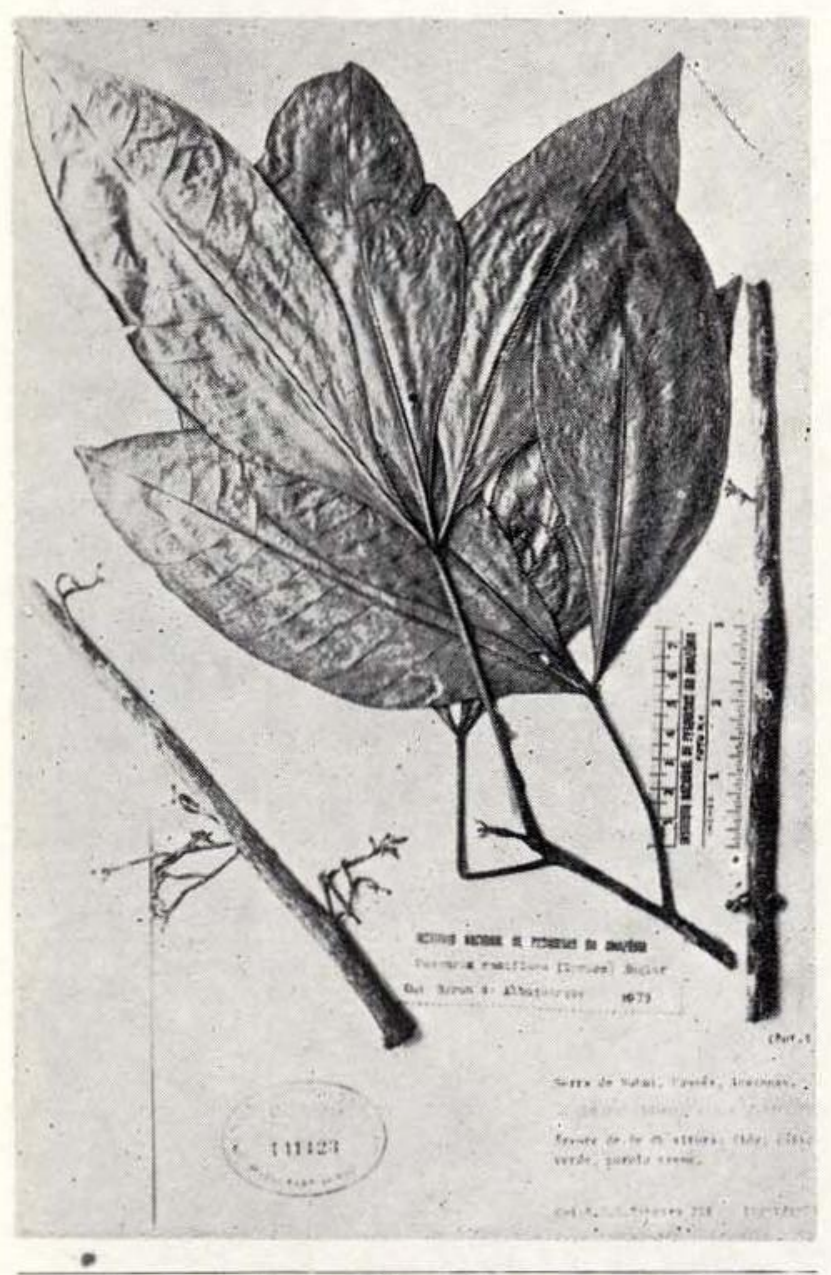

Foto 3. Cusparia ramiflora Spruce ex Engler. Ribeiro 251 (IAN):
2. 2. Cusparia toxicaria Spruce ex Engler, in Mart. Fl. Bras. 12 (2): 144, est. 24 , fig. 1. 1874; Cowan, Mem. N. Y. Bot. Gard. 14 (3): 9. 1967. Fotos 4 e 5.

Arbustos a arvoretas de $3-6 \mathrm{~m}$ de aitura; ramos jovens ferrugíneo-tomentosos. Folhas 5-7- folioladas, pecíolo muito espesso no ápice, curtamente piloso e ruivo por toda parte, depois glabro, tornando-se vermelho; peciólulos muito curtos, espessos na base, folíolos subiguais ou desiguais, largamente lanceolados, atenuados da metade para a base, longamente acuminados, acúmen $2-3 \mathrm{~cm}$ de comprimento, muito agudo, $30-40 \mathrm{~cm}$ de comprimento e 10-14 $\mathrm{cm}$ de largura; nervura mediana espessa; nervuras secundárias, marginais e vênulas reticuladas proeminentes em ambos os lados. Inflorescências racemoso-paniculadas com ramificações laterais curtas, de 1-3 flores, até ca.

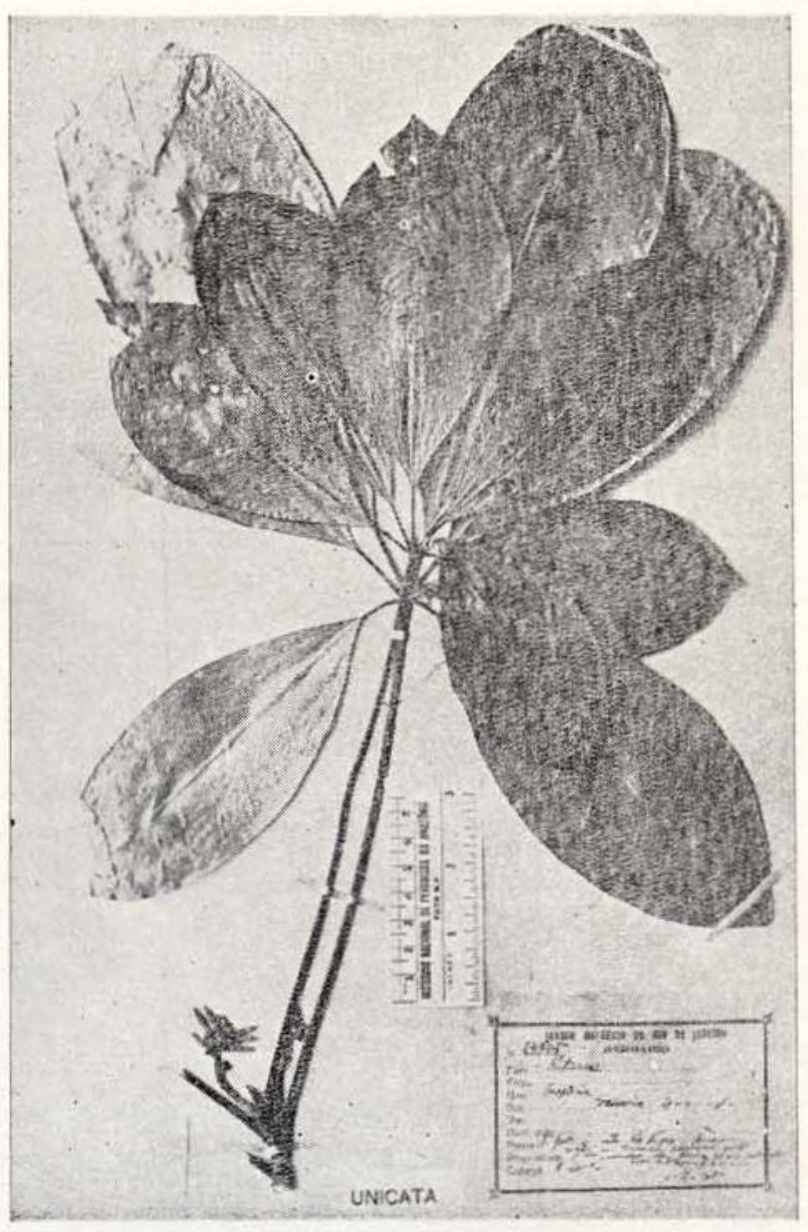

Foto 4. Cusparia toxicaria Spruce ex Engler. Ducke RB 23545. 
de $41 \mathrm{~cm}$ de comprimento; pedúnculo, raque, pedicelos e cálices ruivos, densa e curtamente pilosos. Flores alvas, pentâmeras; cálice cupular, 5-partido, lacínios ovado-triangulares, persistentes e abertos nos frutos; pétalas 5 , densamente pilosas por dentro e por fora, ca. de $15 \mathrm{~mm}$ de comprimento; estames 5,3 férteis, filetes totalmente pilosos, mais longamente barbados por fora abaixo das anteras de $6 \mathrm{~mm}$ de comprimento; disco cupular, 5-dentado: ovário glabrescente, parcialmente incluso no disco, estilete glabro, curvo, capitado. Fruto cocas maiores, conchiformes, crustáceas, pouco brilhantes, $17 \mathrm{~mm}$ de comprimento; semente 1 , oblonga, nítida.

TIPOS - Spruce 2171. Brasil. Amazonas, São Gabriel da Cachoeira (holótipo B, perdido; isótipo: provavelmente em $\mathrm{K}$ ).
DISTRIBUiçÃo - Brasil, Amazonas, região do alto rio Negro, São Gabriel da Cachoeira e circunvizinhanças, e na Bahia (Engler, 1874). Habita em margem rochosa de rios e igarapés das terras firmes baixas. Flores em dezembro e janeiro do ano seguinte. BRASIL. Amazonas: Ducke RB $23545 \mathrm{fl}$ (RB); Ribeiro $240 \mathrm{fl} \mathrm{e} \mathrm{tr}$ (IAN). Fig. 2.

NOME VULGAR E USOS - Brasil. Angustura venenusa (Amazonas, São Gabriel da Cachoeira). Segundo LeCointe (1947) Cusparia toxicaria possui princípios ativos tóxicos, porém em pequenas doses pode ser usada na medicina caseira como febrífuga e emenagoga. Cowan (1967) salienta que a casca desta espécie é empregada como veneno para matar peixes em algumas regiões do sul do Brasil.

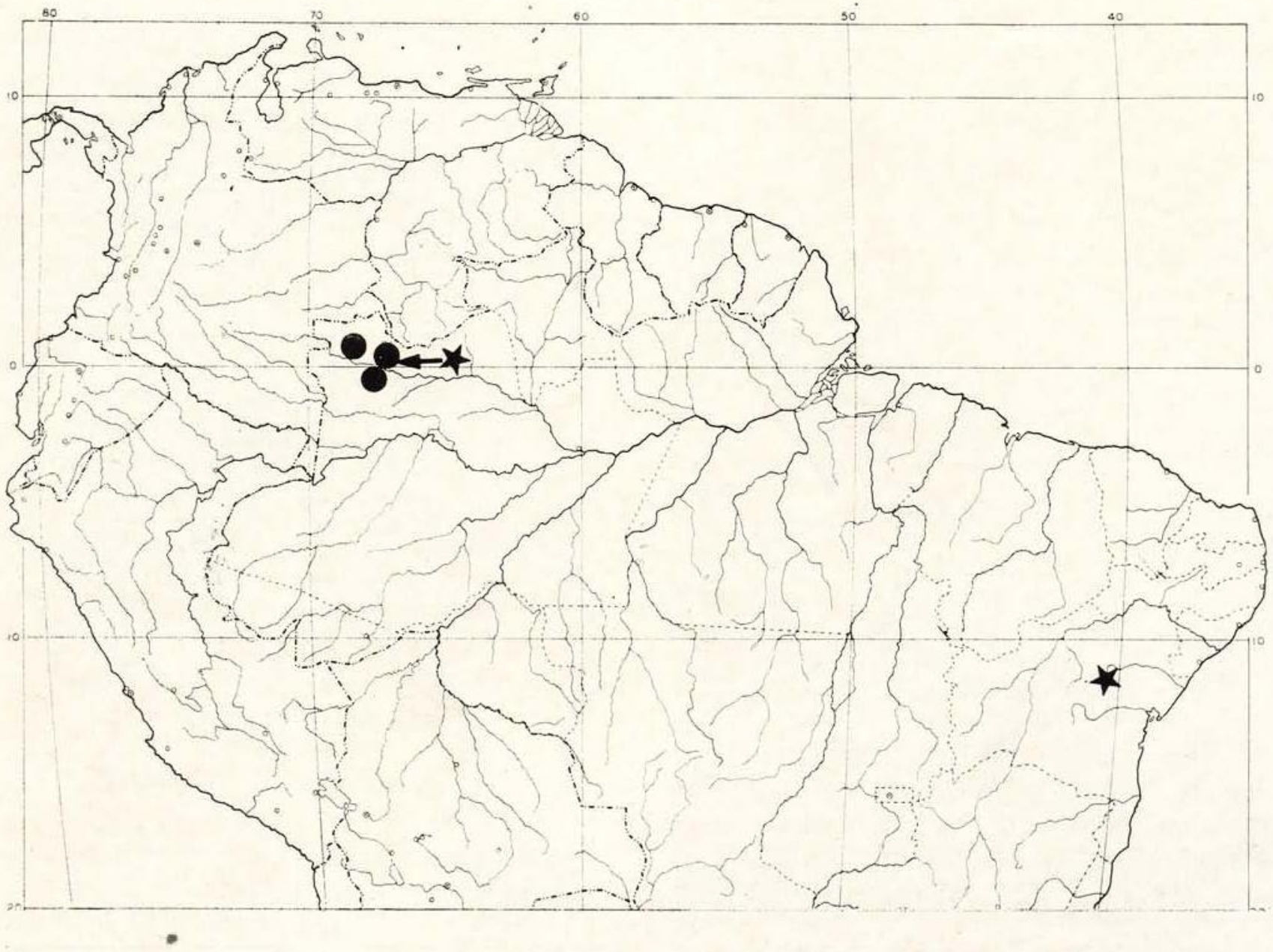

Fig. 2. Distribuição geográfica de 
Cusparia toxicaria distingue-se de $C$. ramı. flora principalmente pelas folhas 5-7-folioladas, inflorescências racemoso-paniculadas, longas e flores pentâmeras.

A espécie Cusparia magdalenensis descrita por Cuatrecasas (1952) para a Colômbiá, de certo modo tem afinidade com $C$. toxicaria, porém diferente por apresentar folhas com 5 folíolos, corola quase regular, com 2 pétalas ligeiramente menores que as outras 3 e todas soldadas em um tubo no terço inferior; 5 estames iguais e todos férteis, com anteras muito estreitas, longas e agudas, exsertas e arqueadas na antese; ovário umbilicado; estilete único, três vezes mais longo que o ováriu.

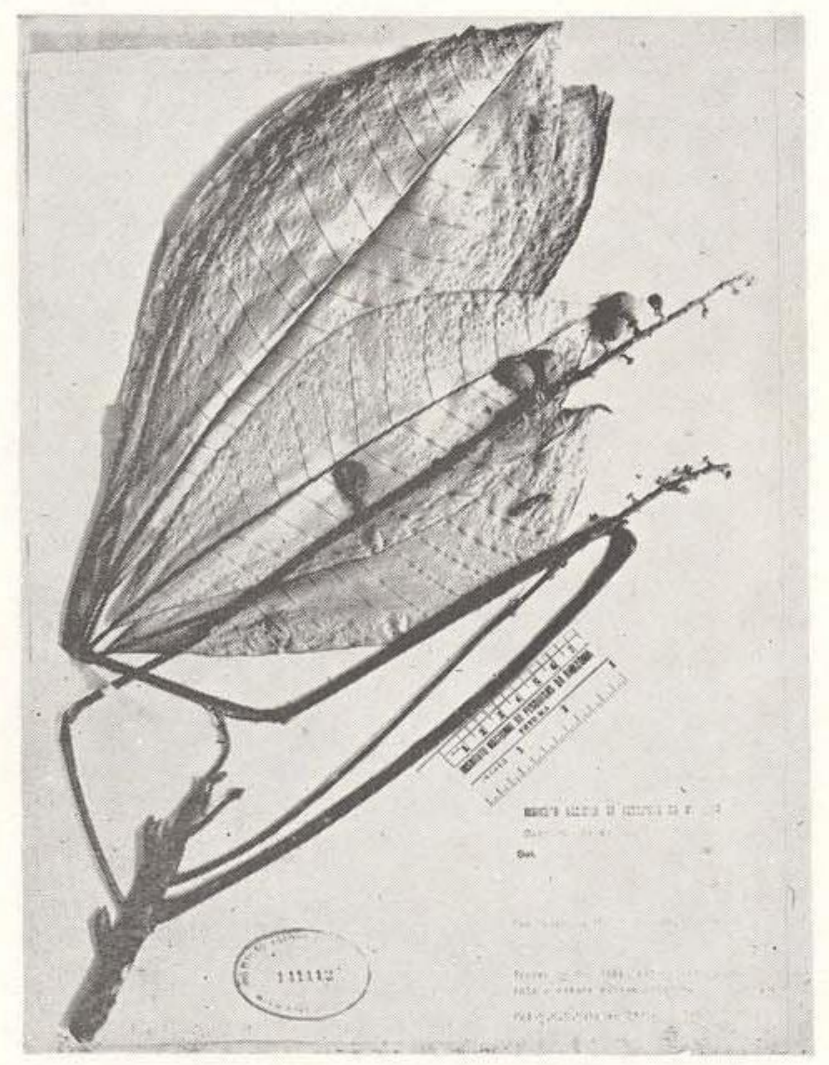

Foto 5. Cusparia toxicaria Spruce ex Engler Ribeiro 240 (IAN).

3. Decagonocarpus Engler, in Mart. FI. Bras. 12 (2) : 105. 1874; Cowan, Mem. N. Y. Bot. Gard. 14 (3) : 6. 1967.

- Subarbusto a arbusto até ca. de $2 \mathrm{~m}$ de altura com ramos quadrangulares, densamente folhosos, pubescentes. Foihas simples, decus- sadas, pecioladas, pecíolo até ca. de $1 \mathrm{~cm}$ de comprimento; lâmina carnosa ou coriácea, ovada, elítica, obovada ou oblanceolado-elitica, glabras por cima e longamente veludosas por baixo quando jovens. Inflorescência em rácemos curtos ou pouco longos, unilaterais ou não, axilares, paucifloros. Flores côr corai, grandes, curtamente pediceladas, hermafroditas, pentâmeras, mais ou menos zigomorfas (cálice); cálice cupular, sub-bilabiado, com 5 lacínios arredondados, ciliados na margem, 1 lacínio maior que os outros; corola bastanto espessa, de 5 pétalas unidas em um tubo longo, cilíndrico, lacínias valvares na prefloração; estames 5 , adnatos à metade do tubo da corola, 2 férteis, inferiores, densamente barbados por dentro, filetes e estaminódios coerentes em um tubo na base, anteras oblongas ou lineares, conectivo apendiculado no ápice; disco cupular, carnoso ou delgado, envolvendo quase totalmente o ovário; ovário obcônico, 5-lobado, 5-locular, óvulos 2 por lócuio, estilete filiforme, estígma levemente capitado ou obliquo. Fruto cápsula 10-angulosa, 5-iocular; carpídios soldados na base, agudamente triangulares, carinados no dorso; semente 2 por carpídio, semiovada, profundamente umbilicada, tuberculado-muricada.

2 espécies ocorrem no Estado do Amazonas. Engier.

Espécie típica: D. oppositifolius Spruce ex

DISTRIBUIÇÃo - Da parte centroeste da Venezuela em direção ao sul até o norte do Amazonas, Brasil.

Decagonocarpus distingue-se dos outros gêneros entre outras características principalmente pelo fruto 10-anguloso.

CHAVE PARA A DETERMINAÇÃO DAS ESPÉCIES DE DECAGONOCARPUS

1. Folhas carnosas, freqüentemente oblanceolado-elíticas; inflorescência unilateralmente racemosa, subescorpióide, até ca 
de 10,2cm de comprimento; cápsula com carpídios munidos de apófise apical prolongada, curva.

\section{1. D. cornutus}

1. Folhas coriáceas, freqüentemente obovadas; inflorescência em rácemos curtos. não escorpióide, até ca. de $4 \mathrm{~cm}$ de comprimento; cápsula com carpídios não mu. nidos de apófise apical, prolongada.

\section{2. D. oppositifolius}

3. 1. Decagonocarpus cornutus Cowan, M. N. Y. Bot. Gard. 10 (1): 1953, fig. 18. 1958 e 14 (3): 6. 1967.

Subarbusto a arbusto, 1-2m de altura, ramos glabros ou pubérulos, nítidos. Folhas simples, decussadas, pecíolos glabros, cilíndricos, até ca. de $10 \mathrm{~mm}$ de comprimento; lâminas espessas, carnosas, translúcido-pontuadas, oblanceolado-elíticas ou elíticas, giabras, base cuneado-aguda, ápice de agudo-acuminado a arredondado, margem estreitamente muito revoluta, $2,5-7 \mathrm{~cm}$ de comprimento e $1,2-3 \mathrm{~cm}$ de largura, nervuras obscuras por cima, nervura mediana proeminente e nervuras secundárias em diante subobscuras por baixo. Inflorescência unilateralmente racemosa, subescorpióide. Flores côr coral; cálice cupular, 2,5-5mm de comprimento, lacínios triangulares; corola carnosa, tubo $23-28 \mathrm{~mm}$ de comprimento, glabra por fora e vilosa por dentro, lacínias $5,5-8 \mathrm{~mm}$ de comprimento, lanceoladas, cilioladas, patentes; estames 5,2 férteis, filetes em tubo coerente na base, anteras oblongas, providas de apêndices flabelados na base; disco carnoso, glabro; ovário 5-locular, carnoso, estilete $23 \mathrm{~mm}$ de comprimento com o ápice esparsamente pubérulo, estígma oblíquo, pubérulo. Fruto 5-partido; carpídios providos de apófise apical prolongada e curva, $2-4 \mathrm{~mm}$ de comprimento, dorso unicarinado, transversalmente muito arqueado-sulcados; semente oblonga, tuberculado-muricada, negra, $4 \mathrm{~mm}$ de comprimento.

Decagonocarpus cornutus distingue-se de C. oppositifolius principalmente pelas folhas carnosas, freqüentemente oblanceolado-elíticas, margem revoluta, inflorescência unilate. ralmente racemosa, subescorpióide e carpidios munidos de apófise apical prolongada.

\section{Decagonocarpus cornutus Cowan var. cornutus} Cowan, Mem. N. Y. Bot. Gard 10 (1): 155, fig. 18. 1958 e 14 (3): 6. 1967. Foto 6.

Folhas não densas, maiores $(3-6 \mathrm{~cm}$ de comprimento, $1,5-3 \mathrm{~cm}$ de largura), pecíolos mais longos (4-8mm de comprimento); cálice glabro, lacínios triangulares; tubo da corola mais longo (27-28mm de comprimento).

TIPO - Maguire 35118. Venezuela. Territóric Amazonas, rio Manapiare, Cerro Yutaje, $\mathrm{fl}$ e $\mathrm{fr}$ (holótipo NY, n. v.).

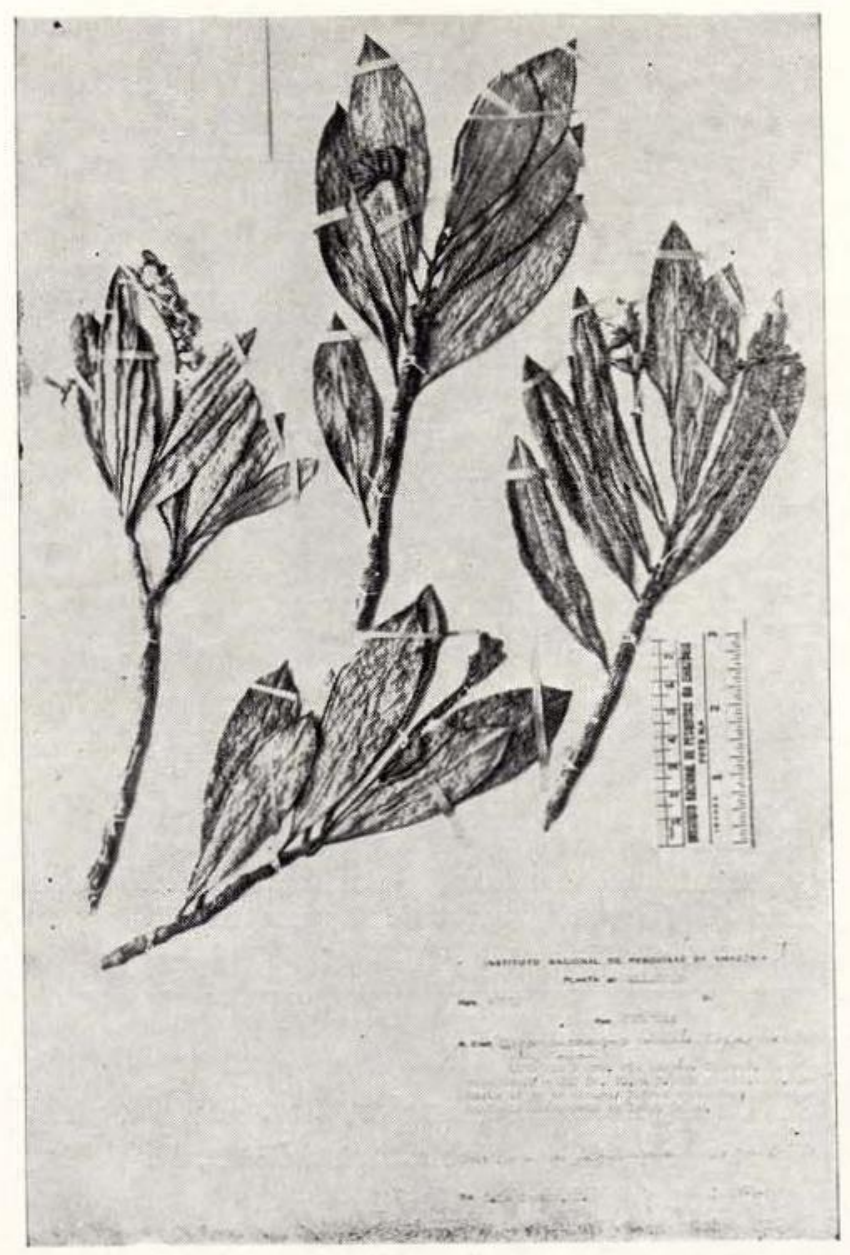

Foto 6. Decagonocarpus cornutus Cowan var. cornutus. Coelho y (INPA). 
DISTRIBUição - Do centroeste da Venezuela, Territorio Amazonas ao norte do Brasil, Estade do Amazonas, rio Vaupés, lauaretê. Abundante em elevações de local úmido e em lugares protegidos entre rochas. Colhida com flores e frutos em fevereiro e maio. BRASIL. L. Coelho $7 \mathrm{fl}$ e fr (INPA). Fig. 3 .

\section{2. Decagonocarpus oppositifolius Spruce ex} Engler, in Mart. FI. Bras. 12 (2) : 105 , tab. 21, fig. 2. 1874; Cowan, Mem. N. Y. Bot. Gard. 10 (1): 153. 1958 e 14 (3): 6. 1967. Foto 7.

Subarbusto a arbusto, ramos levemente angulosos, pouco ramificados, densamente foIhosos, casca fina, cinzenta, brilhante. Folhas simples, decussadas; pecíolos densamente pilosos, 4-8mm de comprimento; lâminas coriáceas, obovadas, elíticas ou ovadas, base cuneado-aguda, ápice de obtuso a arredondado, glabérrimas por cima, inicialmente providas de pêlos longos, depois glabras com exceção da nervura mediana, muito densamente munidas de glândulas translúcidas, $3,5-7 \mathrm{~cm}$ de comprimento e $2,5-3,5 \mathrm{~cm}$ de largura. Inflorescência em rácemos curtos, até ca. de $4 \mathrm{~cm}$ de comprimento, angulosos, avermelhados, densamente pilosos, depois parcialmente pilosas. Flores côr coral; cálice cupular, membranáceo, curtamente piloso, $2 \mathrm{~mm}$ de altura, lacínios $2 \mathrm{~mm}$ de largura, o maior $0,5 \mathrm{~mm}$ mais longo que os outros; corola densamente pubérula por dentro e por fora; estames 5, 2 férteis, densamente barbados por dentro, filetes em tubo coerente na base, antera linear; disco cupular, delgado; ovário 5-locular, óvulos 2 por lóculo, estilete filiforme, do comprimento dos estames férteis, estígma levemente capitacio. Fruto 5-locular; carpídios enegrecidos, ducrsalmente carinados para o ápice, deiscentes em todo o comprimento da região ventral; semente 2, semiovada, ca. de $2,5 \mathrm{~mm}$ de diâmetro, pardo-escuras, tuberculado-muricadas.

TIPo - Spruce 3394. Venezuela. Território Amazonas, próximo ao canal Cassiquiare, fl (holótipo: B, perdido; isótipo: possivelmente em K).

DISTRIBUIÇÃo - Região fronteiriça do sul da Venezuela, Territorio Amazonas e o norte do Brasil, Estado do Amazonas, alto rio Negro, Cucui. Aparentemente restrita às matas um pouco abertas sobre rochedos ao longo dos rios de terras baixas. Colhida com flores em setembro. BRASIL. Amazonas: Ducke RB 34972 $f l(R B)$. Fig. 3.

Decagonocarpus oppositifolius difere de D. cornutus por apresentar principalmente folhas coriáceas, freqüentemente obovadas, inflorescência em rácemos curtos não unilaterais nem subescorpióides, e carpídios não munidos de apófise apical prolongada.

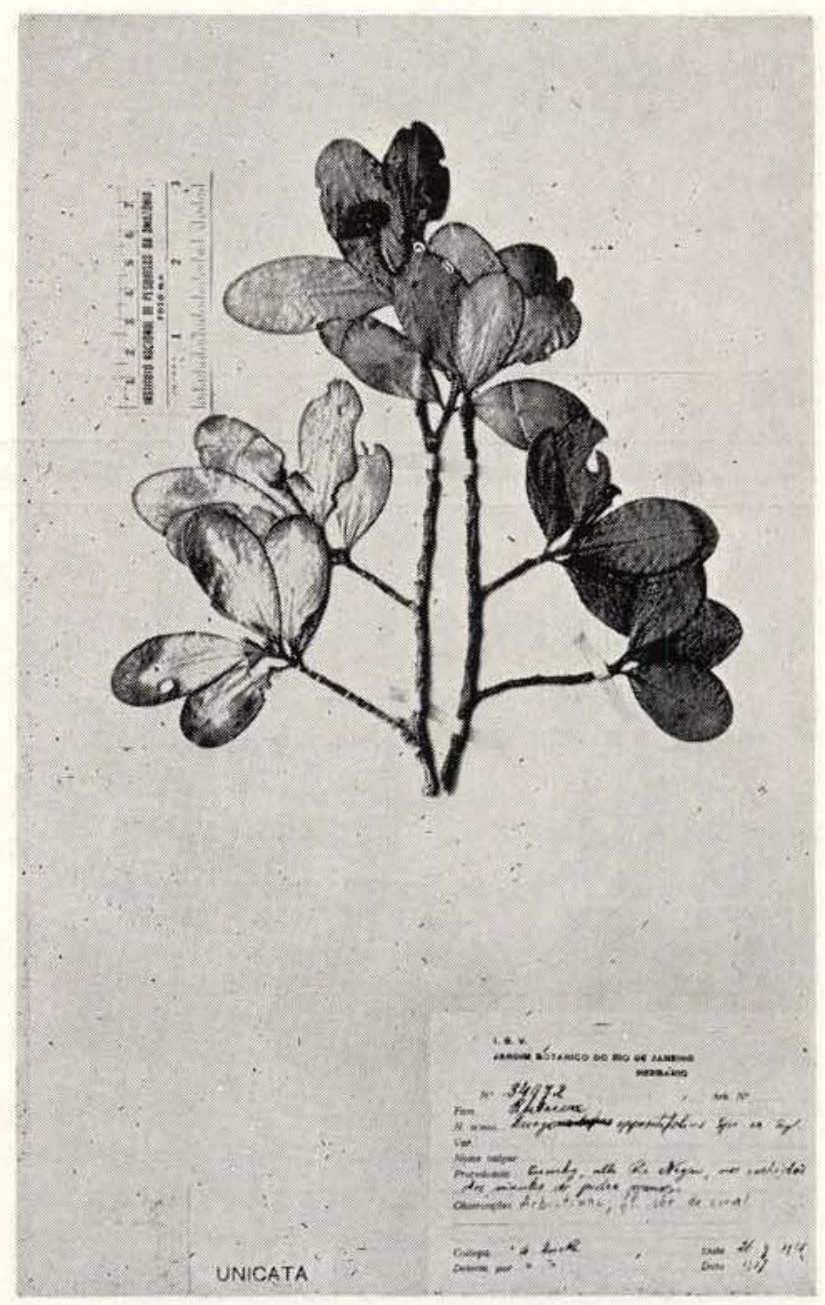

Foto 7. Decagonocarpus oppositifolius Spr. ex Engl. Ducke RB 34972. 


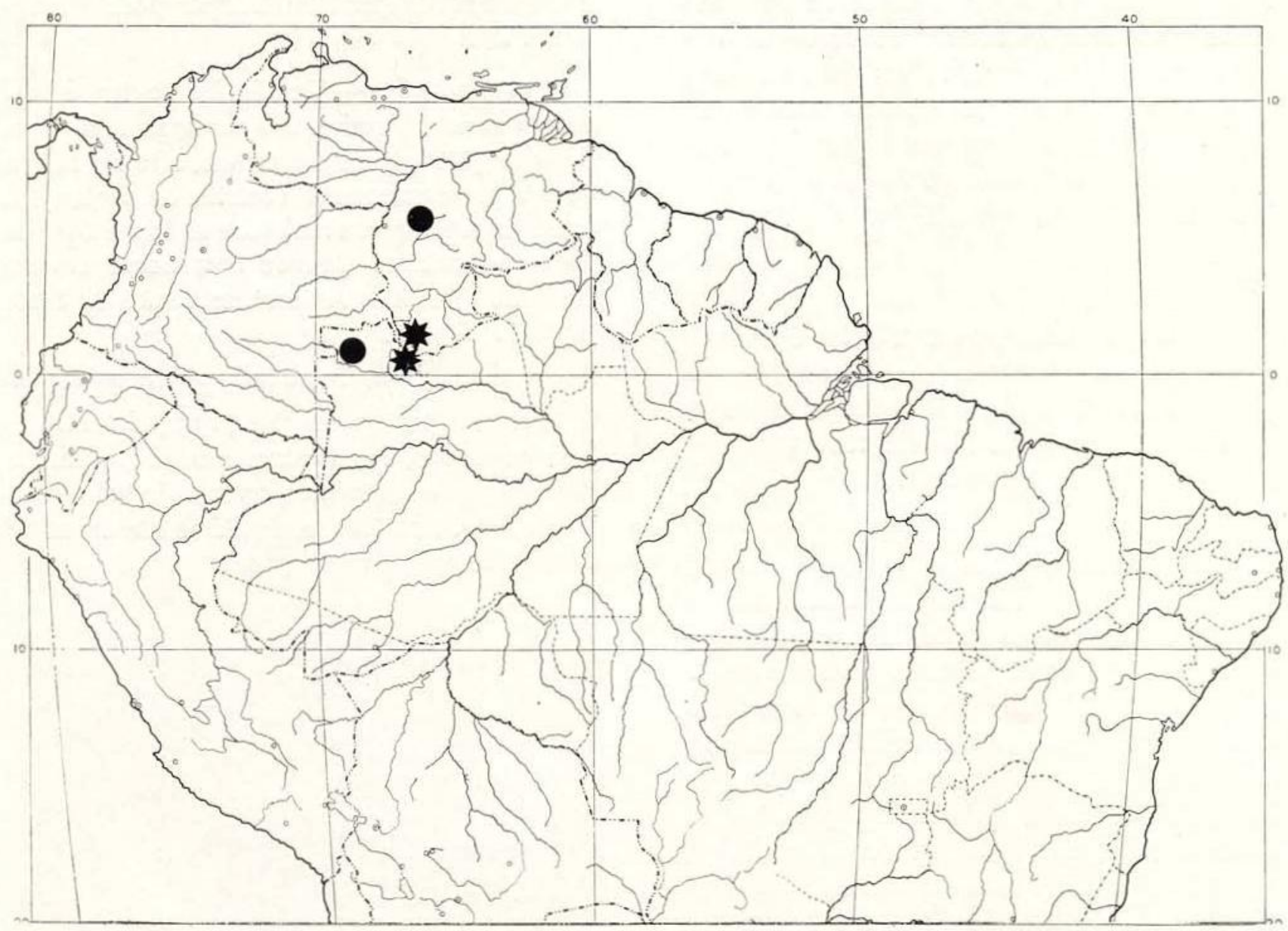

Fig. 3. Distribuição geog̨ráfica de

Decagonocarpus cornutus var. cornutus e * D. oppositifolius.

4. Erythrochiton Nees \& Martius, Nov. Act. Nat. Cur. 11: 151, 165, t. 18 D. 1823; Candolle, Prodromus 1: 732. 1824; Bentham \& Hooker, Gen. PI. 1: 284. 1867; Engler, in Mart. FI. Bras. 12 (2): 106. 1874; Albuquerque, An. Acad. brasil. Ci., 40 (4): 516. 1968.

Pentamorpha Scheidweiler, Bull. Acad. Brux 2(1) : 20. 1842. (*)

Subarbusto a arvoreta até $4 \mathrm{~m}$ de aitura, caule não ramificado. Folhas simples, grandes, inteiras, espiraladas, aglomeradas no ápice do caule, até ca. de $66 \mathrm{~cm}$ de comprimento; pecíolo curto, intumescido no ápice formando um joelho; lamina muito longamente obovado- lanceolada ou oblanceolada ou obovada, base cuneado-atenuada, ápice agudo-acuminado. Inflorescência em panículas racemiformes, Iongipedunculada. Flores alvas, grandes, hermafroditas, pentâmeras, zigomorfas; cálice de 5 sépalas unidas em um tubo 5 -anguloso ou 5 carinado, campanulado, vermelho ou colorido, sub-bilabiado, 2-5-partido, persistente, lacínios ovados, desiguais, 2 inferiores e 3 superiores; corola de 5 pétalas unidas em um tubo cilindrico, reto ou curvo ultrapassando o cálice, lacínias ovado-lanceoladas ou obovadas, subiguais, imbricadas ou reflexo-valvares na prefloração; estames 5 , todos férteis ou 1-3, ou ainda todos estéreis, adnatos ao tubo da corola, filetes unidos na base, anteras lanceoladas;

(•) - Sinônimo citado por Engler (1874) e Cowan (1967). 
disco urceolado; ovário profundamente 5-lobado, 5-locular, incluso disco, cada lóculo com 2 óvulos superpostos ou colaterais, estilete incluso, estígma capitado. Fruto cápsula 5-locular; carpídios levemente coerentes dos lados, cada carpídio dividido em 2 valvas, carinado no dorso; semente subovada, 2 por carpídio, tuberculado-muricada ou verrucosa, densamente adpresso-pilosa.

I espécie ocorre no Estado do Amazonas. Espécie típica: E. brasiliensis Nees \& Mart.

Distribuição - Do sudeste do Brasil, ao longo da América Central, até o México.

Erythrochiton separa-se dos demais gêneros entre outros caracteres por apresentar principalmente o cálice vermelho ou colorido.

Erythrochiton brasiliensis Nees \& Martius, Nov. Act. Nat. Cur. 11: 166, t. 22. 1823; Engler, in Mart. FI. Bras. 12 (2): 107, t. 22. 1874; Ducke, Arch. Jard. Bot. Rio de Janeiro 3: 183. 1922; Engler, in Engler \& Prantl, Nat. Pflanzenf. 3 (4): 165, fig. 96 , A-E, 166. 1896 e $2^{\text {a }}$ ed. $19^{\mathrm{a}}$ : $288-289$, fig. 132, A-E. 1931; Lemée, FI. Gui. Franç. 2: 184. 1952; Albuquerque, An. Acad. brasil. Ci. 40 (4): 517. 1968. Fote 8.

Pentamorpha graveolens Scheidweiler, Bull Acad. Brux. 9(1):21. 1842. Tipo. (não localizado). (")

Subarbusto a arvoreta de ca. de $4 \mathrm{~m}$ de altura. Folhas simples, grandes, membranáceas a subcoriáceas, espiraladas, até ca. de $66 \mathrm{~cm}$ de comprimento; pecíolo curto, intumescido no ápice; lâmina largamente lanceolada ou obovado-lanceolada, inteira, base decurrente, ápice acuminado, ca. de $63 \mathrm{~cm}$ de comprimento e $14 \mathrm{~cm}$ de largura. Inflorescência em panículas racemosas, triangulares, vistosas, com ramificações curtas dispostas no ápice, pedúnculo e raque longos alcançando ca. de $74,5 \mathrm{~cm}$ de comprimento. Flores alvas, dispostas 3 a 3 ou 5 a 5 ou de 8 a 10; cálice em tubo campanulado, grande, vermelho, pouco inflado, 5anguloso, irregularmente 5-partido, bilabiado, um dos lábios freqüentemente ainda dividido, lacinios ovados; corola tubulosa (5 pétalas),

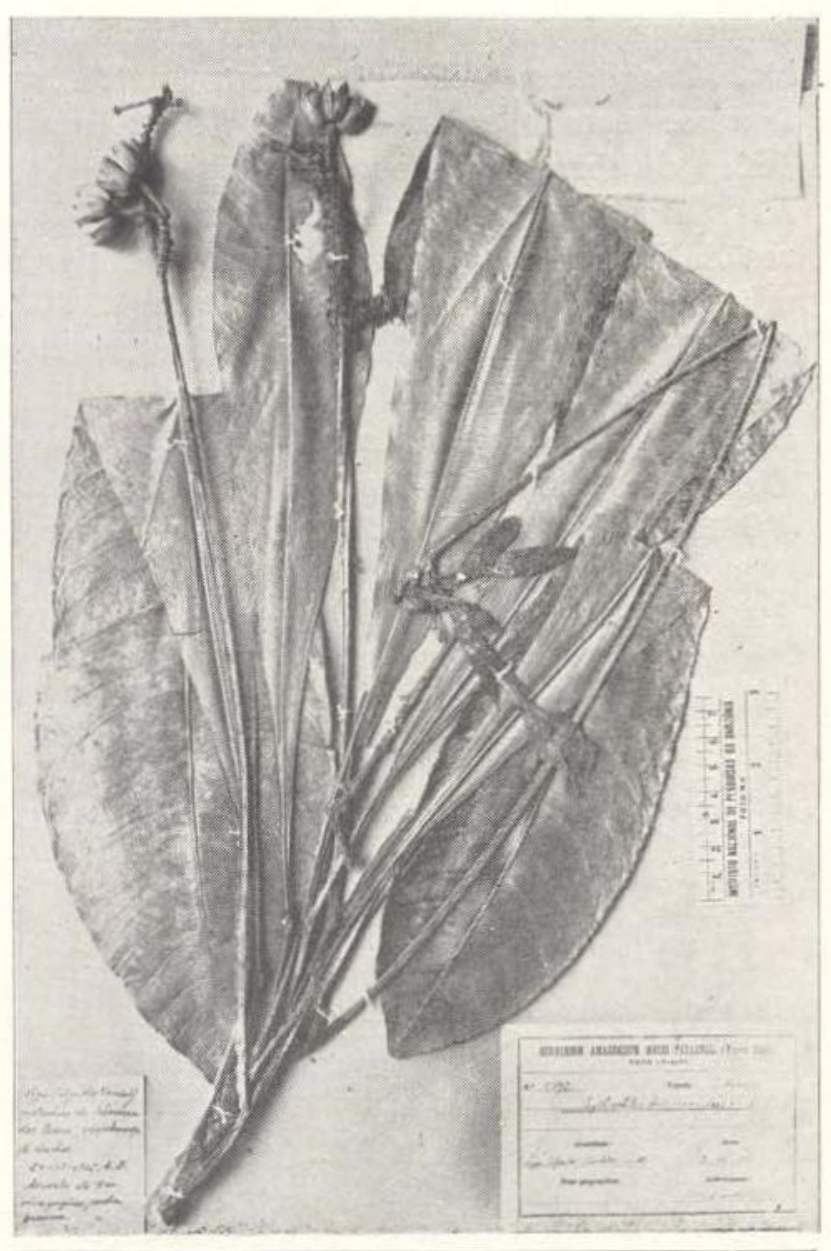

Foto 8. Erythrochiton brasiliensis Nees \& Mart. Ducke MG 15892.

grande, carnosa, tubo pouco mais longo que o cálice, lacínias subiguais, obovadas ou ovadolanceoladas, abertas; estames exsertos, com filetes adnatos à corola até a abertura; disco urceolado, carnoso, envolvendo totalmente o ovário; ovário 5-iobado, 5-locular, lóculo com 2 óvulos superpostos; estígma capitadio. Fruto cápsula vermelha, depois castanha, freqüentemente 5-locular; carpídios crustáceos, pouco concrescidos; semente tuberculado-muricada castanho-clara.

\section{TIPOS - (não localizados).}

DISTRIBUIÇÃo - Das terras baixas do Equador, Peru e Colômbia à costa atlântica, seguindo duas direções. A primeira através da Venezuela, República da Guiana, Suriname e norte do Brasil, e a segunda por entre o sul do

$\overline{(*)-S i n o ̂ n i m o ~ c i t a d o ~ p o r ~ C o w a n ~(1967) . ~}$ 
Amazonas, norte da Bolívia, Mato Grosso, Ba. hia, Minas Gerais, Espirito Santo e Rio de Janeiro. Habita em mata aberta ou primária úmida de terra firme ou em margem de rios ou igarapés, sobre solos não arenosos. Flores de janeiro a dezembro e frutos de março a julho. BRASIL. Amazonas: Boyan $215 \mathrm{fl}$ (INPA); Prance et al. $14686 \mathrm{fr}$ (INPA). Minas Gerais: Barreto $6095 \mathrm{fl}(\mathrm{R})$; Glaziou $1060 \mathrm{fl} \mathrm{e}$ $\mathrm{fr}(\mathrm{R})$. Pará: Cavalcante $333 \mathrm{fl}(\mathrm{MG}) ; 370 \mathrm{fl}$ (MG); Cavalcante \& Silva $2783 \mathrm{fl}(\mathrm{MG})$; Ducke MG $15892 \mathrm{fl}$ (MG, $R$ 2324). Rio de Janeiro:
Freire et al. $R 71433 \mathrm{fl}(\mathrm{R})$; Schreiner $R 7127$ ? $\mathrm{fl}(\mathrm{R})$. Território de Roraima: Prance et al. $9312 \mathrm{fl}$ (INPA); $10926 \mathrm{fr}$ (INPA). PERU. Departamento de Loreto: Ule $6611 \mathrm{fl}$ (MG). Fig. 8.

NOME VULGAR - Brasil. Eritroquíton (região sudeste) .

Usos - A casca da raiz de Erythrochiton brasiliensis é empregada na medicina caseira como vermífugo. Planta bastante ornamental podendo ser usada em ajardinamentos de praças e parques.

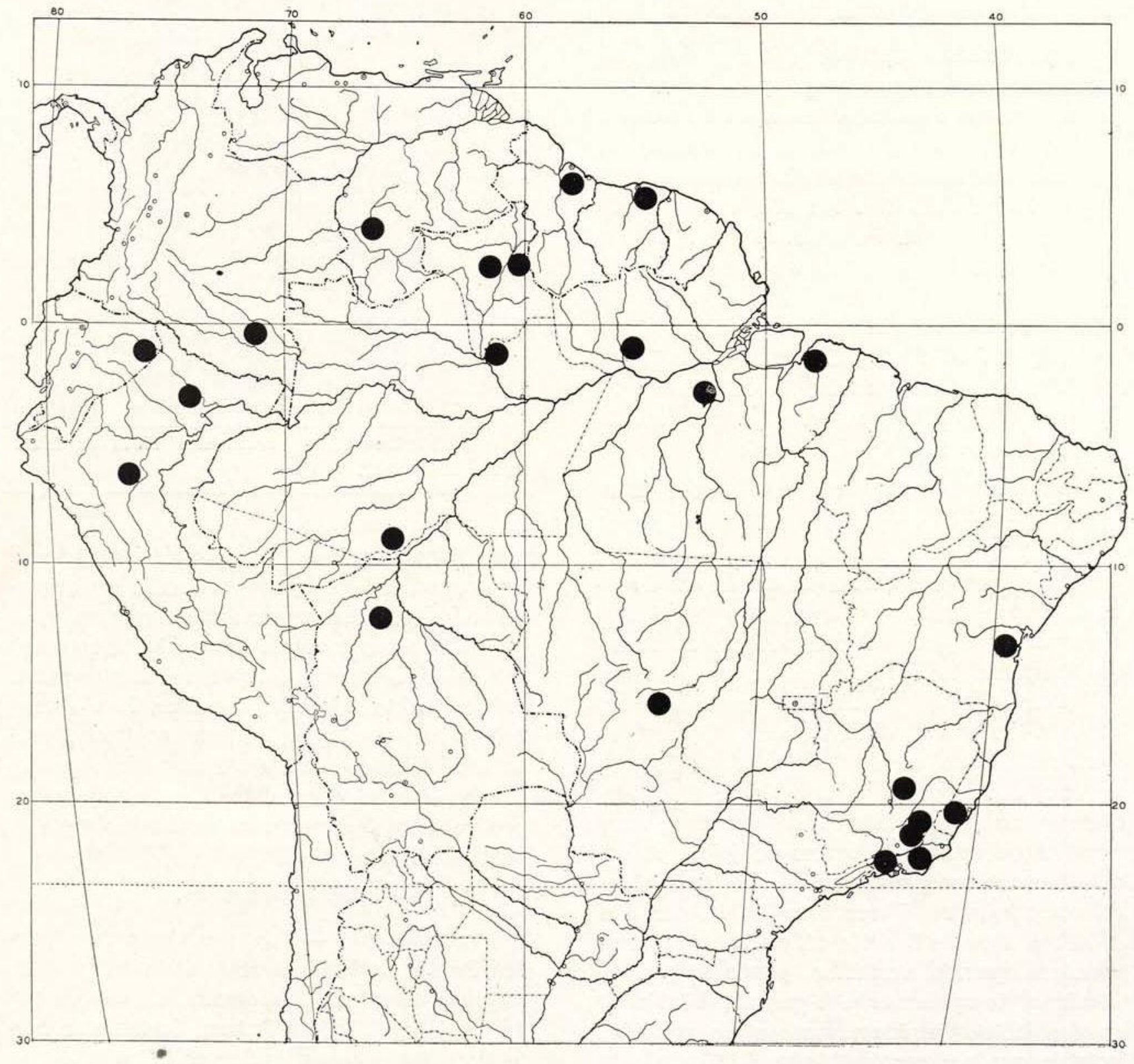

Fig. 4. Distribuição geográfica de Erythrochiton brasiliensis. 
5. Esenbeckia H. B. K., Nov. Gen. et Sp. 7: 246. 1824; Engler, in Mart. Fl. Bras. 12 (2): 139. 1874; Cowan, Sellowia 12: 87. 1960; Albuquerque, An. Acad. brasil. Ci. 40 (4): 508 . 1968.

Colythrum Schott. Rutac. 13. t. 7. 1834. (") Evodia St.-Hil. Pl. Rem. 1: 149. 1824; Fl. Brasil. Mer. 1: 1825; Candolle, Prodromus 1: 724. 1824. (")

Kuala Karst. \& Triana, Linnaea 28:428. 1856. (")

Polembryum A. Juss., Mem. Mus. Par. $12: 519$. 1825. (")

Arbusto a árvore. Folhas simples, alternas, raro aproximadas ou subopostas, membranáceas, raro subcoriáceas; lâmina obovado-ẹlíticas ou oblongo-elíticas, base aguda, ápice acuminado. Intiorescência em panículas de cimeiras, axilares ou terminais, paucifloras e multifloras, pedicelos bibracteolados. Flores pequenas, verde-esbranquiçadas, hermafroditas, pentâmeras, actinomorfas; cálice 5-partido ou 5 sépalas livres, ovadas, obtusas ápice, ımbricadas na prefloração; pétalas 5 , delgadas ou pouco carnosas, oblongo-elíticas ou obovadoorbiculares, imbricadas ou levemente valvares na prefloração; estames 5 , livres, todos férteis, inseridos entre os lobos do disco, filetes subulados, anteras subcordadas, conectivo agudo; disco anelar ou cupular; ovário globoso, deprimido, freqüentemente coberto de numerosos tubérculos, 5-lobado, lobos profundos, 5-locular, óvulos 2 por lóculo, colaterais, raro 1 , estilete basilar, curto, disposto entre os lóculos, estígma simples ou 5-lobado. Fruto cápsula ienhosa, subglobosa, de 5 carpídios, cada carpídio munido de apófise no dorso apical ou a cápsula toda tuberculado-muricada; semente ublonga, 1-2 por lóculo (mais freqüente 1), testa lisa ou rugosa.

\section{1 espécie do Estado do Amazonas.}

Espécie típica: E. pilocarpoides H. B. K.

DistrRIBUiçÃo - Do sul do Brasil e do Paraguai, ao longo da América Central (incluindo as Antilhas) até os Estados Unidos (Texas\}'.
Esenbeckia distingue-se dos demais gêneros principalmente pelo ovário coberto de tubérculos e cápsula munida de apófise no dorso de cada carpídio ou ela toda tuberculado-muricada.

Esenbeckia cornuta Engler, in Mart. FI. Bras. 12 (2): 146. 1874. Fotos 9 e 10.

Arbusto a árvore pequena com ramos densamente folhosos no ápice. Folhas simples, alternas, membranáceas, até ca. de $26 \mathrm{~cm}$ de comprimento e $11 \mathrm{~cm}$ de largura; lâmina oblongo-elítica ou obovado-elítica, base aguda, ápıce agudo-acuminado, acúmen obtuso ou retuso. Inflorescência $\in \mathrm{m}$ panículas de cimeiras, multifloras, axilares ou terminais, densamente pilosas, $10-34 \mathrm{~cm}$ de comprimento. Flores verde-esbranquiçadas, atropurpúreas no centro;

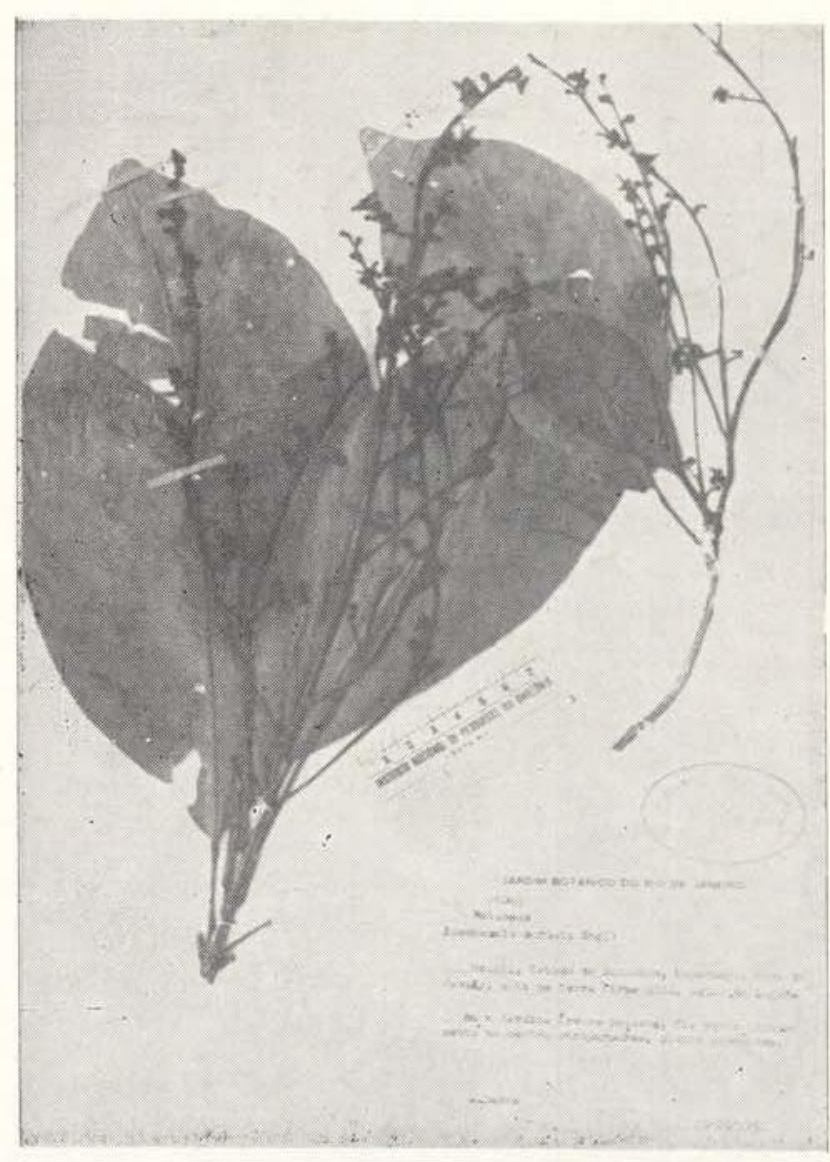

Foto 9. Esenbeckia cornuta Engl. Ducke RB 25065 (INPA 50604).

(*) - Sinônimos citados por Engler (1874). 
sépalas 5, livres, ovadas, obtusas ou subagudas no ápice, pilosas por fora e glabras por dentro, ciliadas na margem, imbricadas na prefloração; pétalas 5 , livres, ovado-lanceoladas, pilosas por fora e glabras por dentro; estames 5 , todos férteis, filetes subulados, anteras obcordadas; disco curto, anelar, 10-plicado; ovário seríceo, incluso no disco, estilete coroado. Fruto cápsula 5-locular, lenhosa; carpidios subtrigonais, glabrescentes, providos de apófise ascendente a altura da metade do dorso, ca. de $16 \mathrm{~mm}$ de comprimento por $23 \mathrm{~mm}$ de largura; semente 1 , oblonga, pouco áspera na superfície, endocarpo amarelo.

TIPOS - Warszewicz $s / n$. Brasil. Amazonas, fl (holótipo B, perdido; foto holótipo: NY).

DISTRIBUIÇÃo - Desde o nordeste do Peru até a parte ocidental fronteiriça do Estado do

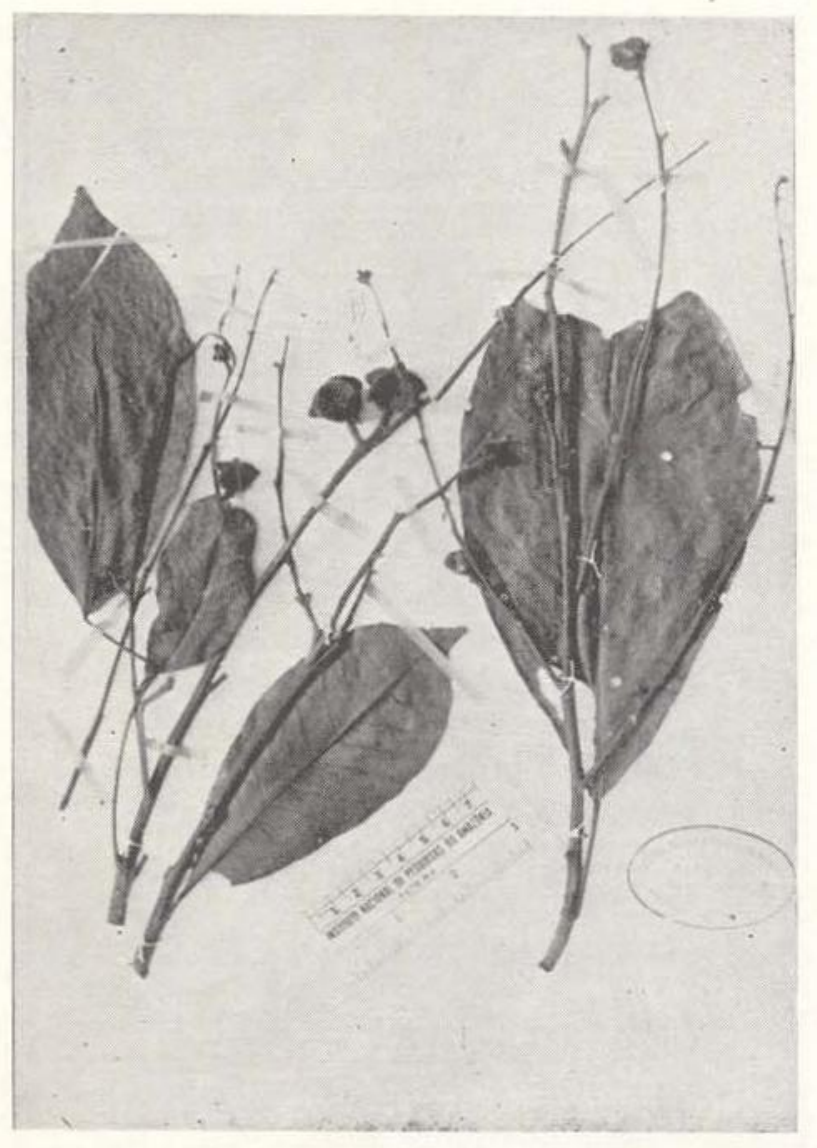

Foto 10. Esenbeckia cornuta Engl, Ducke RB $\mathbf{5 0 8 1 5}$ (INPA 50603).
Amazonas, Brasil. Habita em mata primárıa de terra firme alta ou baixa. Colhida com flores e frutos em setembro. BRASIL. Amazonas: Ducke $1266 \mathrm{fl}$ e fr (MG, RB, INPA); $R B$ $25065 \mathrm{fl}$ (RB; INPA 50604). Fig. 5.

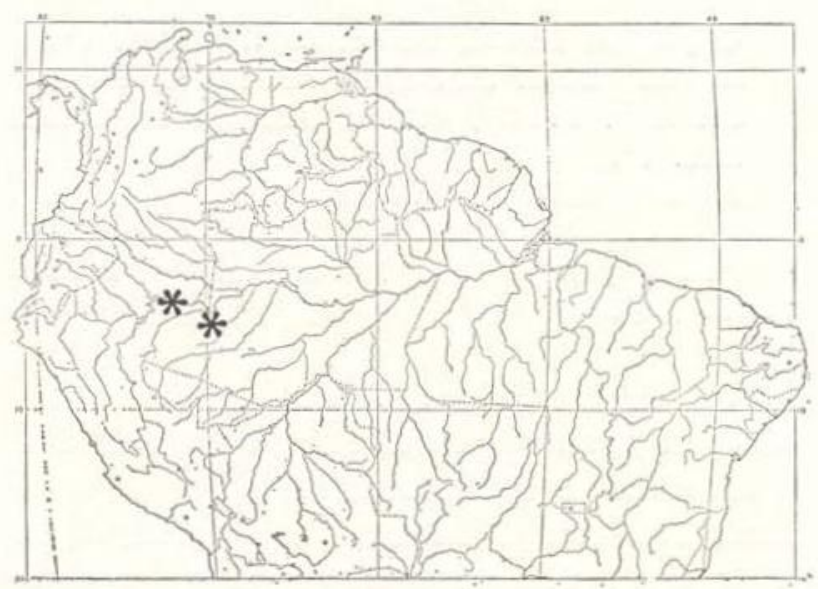

Fig. 5. Distribuição geográfica de * Eser.beckia cornuta.

6. Galipea Aublet, Hist. PI. Gui. Franç. 2: 662. 1775; Engler, in Mart. FI. Bras. 12 (2): 95. 1874; Cowan, Mem. N. Y. Bot. Gard. 14 (3): 5. 1967; Aibuquerque, An. Acad. brasil. Ci. 40 (4): 514. 1968.

Costa Vellozo, Fl. Flum. 19. 1825; I, t. 48. 1827. (*)

Endostephium Turcz., Bull. Soc. Nat. Mosc 36(2) : 227. 1823. (*)

Sciuris Nees \& Mart., Nov. Act. Nat. Cur. 11 : 150-153. 1823. (")

Systemon Regel, Ind. Sem. Hort. Petrop. 33. 1856. (")

Ticorea St.-Hil. Bull. Soc. Philom. 132. 1823. (*)

Subarbusto a árvore até ca. de $10 \mathrm{~m}$ de altura, de ramos avermelhados, densamente foIhosos. Folhas alternas, unifolioladas ou trifolioladas, membranáceas, pecíolos pouco alados ou não; lâmina folioiar oblongo-elítica, base aguda, ápice agudo-acuminado, acúmen emarginado. Inflorescência em panículas axilares ou terminais. Flores alvas, grandes, hermafroditas, pentâmeras, zigomorfas, de androceu irregular; cálice pequeno, cupular, 5laciniado, lacínios agudos, eretos; corola de 5 pétalas unidas em um tubo hipocrateriforme,

*) - Sinônimos mencionados por Engler (1874) e Cowan (1967). 
cilíndrico, estreito, reto, várias vezes mais longa que o cálice, freqüentemente fina, lacínias desiguais, imbricadas na prefloração; estames 5-7, 2 férteis, os outros reduzidos a estaminódios, filetes e estaminódios unidos em um tubo soldado à corola, estaminódios terminando ou não em glândula globosa, anteras oblongo-lineares, conectivo apendiculado na base; disco cupular; ovário globoso, profundamente 5-lobado, 5-locular, envolvido pelo disco, lóculo com 2 óvulos superpostos, estilete mais ou menos do comprimento da corola, 5-anguloso, estígma obliquamente truncado, 5-lobado. Fruto cápsula de 5 carpídios unidos na base e no ápice; carpídios oblongos, subtriangulares; semente 1 , oblonga, lateralmente pouco comprimida.

2 espécies do Estado do Amazonas.

Espécie típica: G. trifoliata Aublet.

DISTRIBUIÇÄo - Do sul do Brasil até a América Central (Panamá, Guatemala, Nicarágua) .

Galipea difere dos outros gêneros por apresentar principalmente folíolos com o ápice emarginado e flores estreitamente cilíndricas e finas.

CHAVE PARA A DETERMINAÇÃo

DAS ESPÉCIES DE GALIPEA

1. Folhas unifolioladas.

6. 1. G. grandifolia

1. Folhas trifolioladas.

6. 2. G. trifoliata

6. I. Galipea grandifolia Engler, in Mart. Fi. Bras. 12 (2) : 98. 1874; Cowan, Mem. N. Y. Bot. Gard. 14 (3): 6. 1967. Foto 11.

Arbusto a árvore pequena. Folhas grandes, unifolioladas, glabérrimas em ambas as faces, $15-25 \mathrm{~cm}$ de comprimento e $6-7 \mathrm{~cm}$ de largura; pecíolos curtos, subcilíndricos; lâminas oblongo-elíticas, base aguda, ápice acuminadơ, acúmen longo, emarginado; nervuras mediana, secundárias e vênulas reticuladas proeminentes por cima e por baixo. Inflores- cência em panículas que alcançam a metade das folhas, com ramificações de 3-7 flores. Flores alvas, mais longas, até ca. de $4 \mathrm{~cm}$ de comprimento; cálice cupular, sinuoso-dentado, lacínios muito curtos; corola de tubo alongado (até ca. de $3 \mathrm{~cm}$ de comprimento), pubérula, lacínias linear-oblongas, agudas, recurvadas; estames 7, 2 férteis e 5 estaminódios; ovário com estilete filiforme, ca. de $3 \mathrm{~cm}$ de comprimento, ultrapassando a abertura da corola. Fruto cápsula 5-locular; carpídios oblongos, triangulares, carinados no dorso, curtamente apiculados, deiscentes em toda a região ventral prolongando pelo ápice até acima da metade do dorso, inicialmente concrescidos dos lados, depois livres, ca. de $1,5 \mathrm{~cm}$ de comprimento e $0,5 \mathrm{~cm}$ de largura.

TIPOS - Spruce 2822. Brasil. Amazonas, rio Vaupés, próximo de Panuré (holótipo: B, perdido; isótipo: provavelmente em $\mathrm{K}$ ).

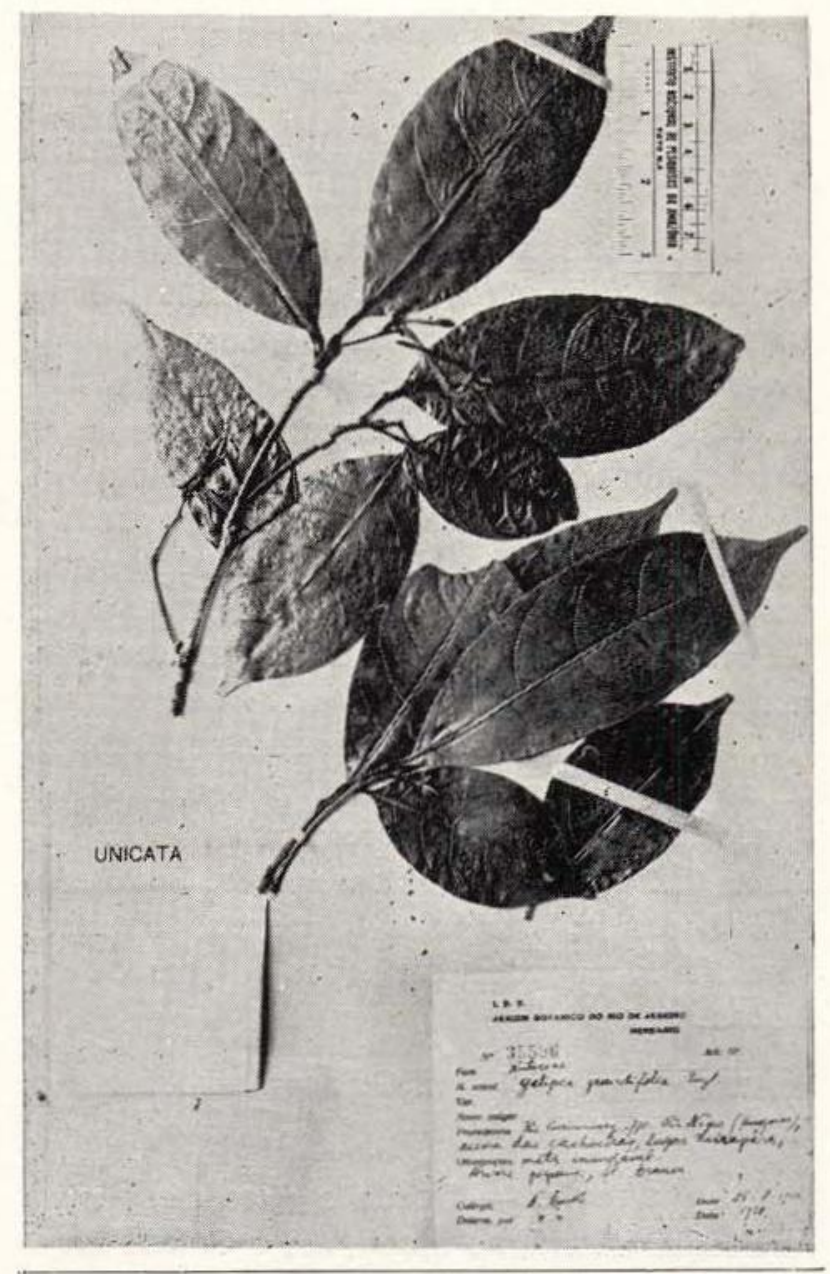

Foto 11. Galipea grandifolia Engler. Ducke RB 35596 . 
DISTRIBUição - Brasil, Estado do Amazo nas, desde a parte ocidental quase fronteira com o Peru em direção ao norte, até a região do alto rio Negro com o rio Vaupés. Habita em mata primária inundável de margem de igarapé. Colhida com flores em dezembro e em janeiro do ano seguinte. BRASIL. Amazonas: Ducke $35596 \mathrm{fl}$ (RB); IAN $43450 \mathrm{fl}$ (IAN). Fig. 6.

Galipea grandifolia distingue-se de G. trifoliata principalmente pelas folhas unifolioladas.

6. 2. Galipea trifoliata Aublet, Hist. PI. Gui. Franç. 2: 662, t. 269. 1775; Engler, in Mart. FI. Bras. 12 (2): 96. 1874; Lemée, FI. Gui. Franç. 2: 183.1952. Foto 12.

Sciuris corymbosa Spreng., 1:38, 1823. (") Tipo: (não localizado).

Sciuris trifoliata Nees \& Mart., Nov. Act. Nat. Cur. 12:155. 1823. (*) (holótipo) Herbário M, n.v.).

Subarbusto a árvore mediana até ca. de $8 \mathrm{~m}$ die altura, de folhagem aromática. Folhas trifolioladas, muito finamente pilosas quando jovens, depois glabérrimas por cima e por bai$\mathrm{xo}$, enegrecidas quando secas; pecíolos muito estreitamente alados; folíolos oblongo-elíticos, desiguais, o apical maior, de base atenuada e os laterais de base oblíqua, ápice acuminado, acúmen emarginado. Inflorescência em panículas terminais e axilares; ramificações finas geralmente com 3 flores. Flores alvas, aromáticas, menores, até ca. de $2 \mathrm{~cm}$ de comprimento; cálice cupular, parcialmente piloso, lacínios curtos, pouco obtusos; corola pubescente; estames 7, 2 férteis e 5 estaminódios. Fruto cápsula 5-locular; carpídios oblongos, obtusos, ventralmente agudos, carinados no dorso, crustáceos.

тIPO - Aublet $s / n$. Guiana Francesa. (Holótipo $\mathrm{P}, n$. v.).

DISTRIBUiÇão - Desde o Acre através do Amazonas e Pará, no Brasil, até a Guiana Fran-

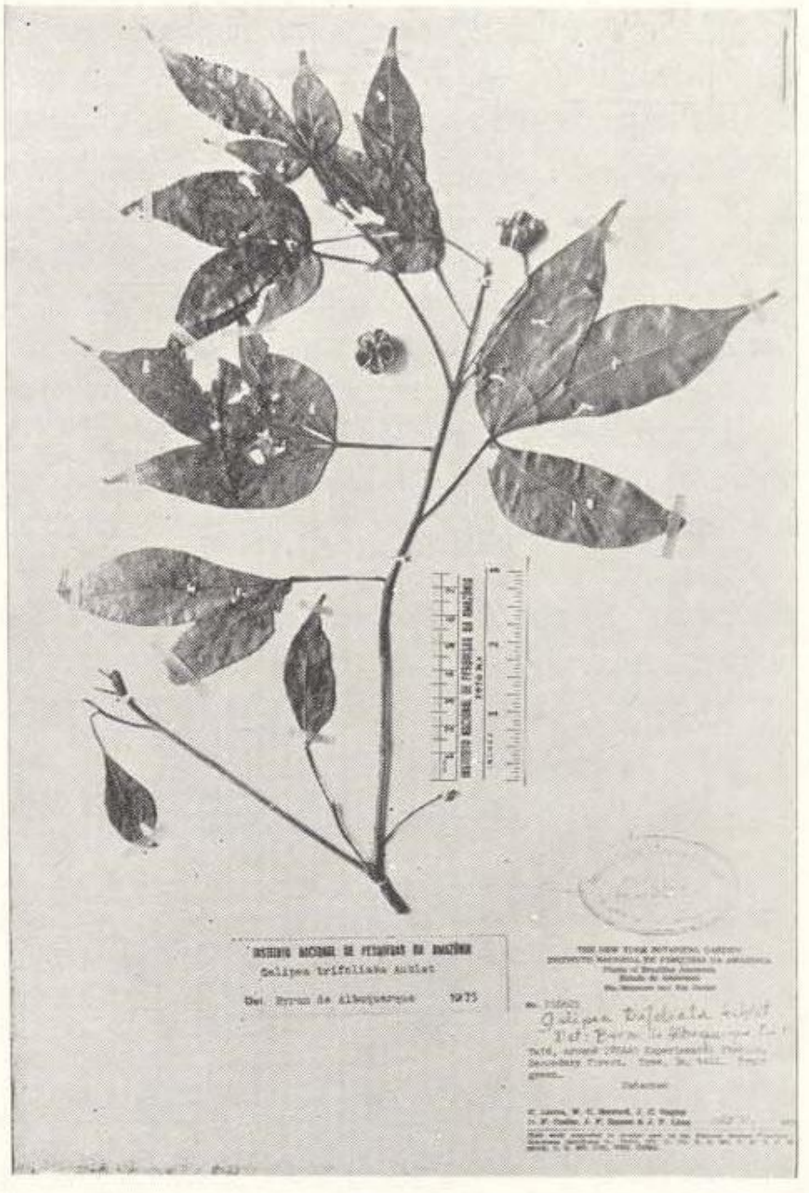

Foto 12. Galipea trifoliata Aubl. Prance et al. 16621 (INPA).

cesa. Habita em pastos secos, mata secuidária de terra firme ou em margem de rios. Flores em fevereiro, maio, agosto e setembro, e frutos em maio, julho e agosto. BRASIL. Acre: Forero et al. $6327 \mathrm{fr}$ (INPA). Amazonas: Black $1209 \mathrm{fl}$ e fr (IAN); Fróes $26103 \mathrm{fl}$ (IAN); Prance et al. $16621 \mathrm{fr}$ (INPA); Silva et al. 387 fr (INPA). Pará: Lima 53-1477 fl e fr (IAN). Fig. 6.

NOME VULGAR - Zona do Caribe: Inga.

Galipea trifoliata separa-se de G. grandifolia entre diversos caracteres por apresentar principalmente folhas trifolioladas.

Segundo Engler (1874) Galipea trifoliata também está citada para o Estado da Bahia.

(*) - Sinônimos citados por Engler (1874). 


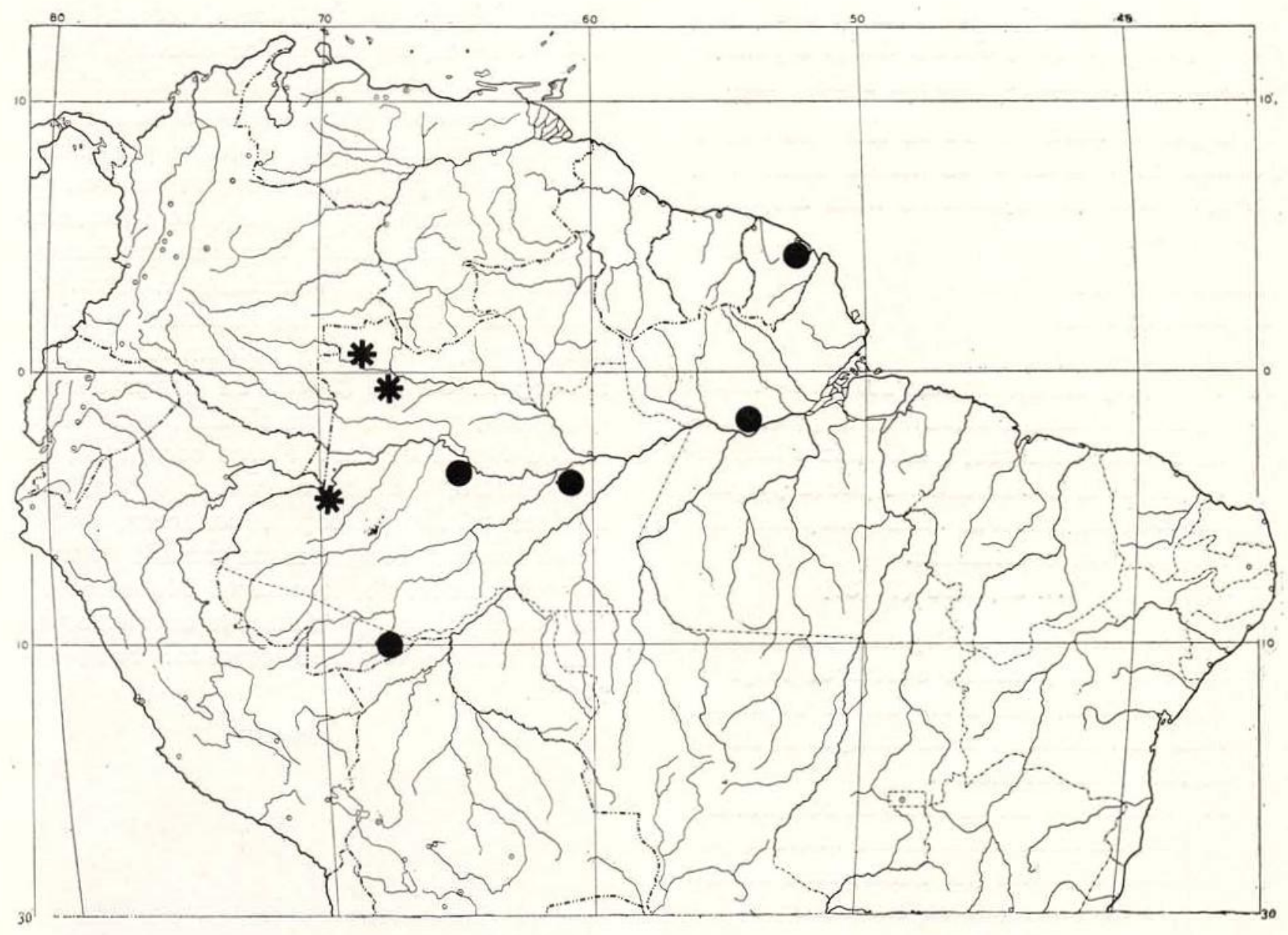

Fig. 6. Distribuição geográfica de * Galipea grandifolia e - G. trifoliata.

7. Hortia Vandelli, FI. Lus. et Bras. 14. 1788; Roem. Script. 188. 1796; Engler, in Mart. Fl. Bras. 12 (2): 181. 1874; Cowan, Mem. N. Y. Bot. Gard. 14 (3): 4. 1967; Albuquerque, An. Acad. brasil. Ci. 40 (4): 523. 1968.

Arbusto a árvore até ca. de $20 \mathrm{~m}$ de altura. Folhas simples, espiraladas, coriáceas a rígidas, glabras ou pilosas, até ca. de $125 \mathrm{~cm}$ de comprimento e $20,5 \mathrm{~cm}$ de largura na parte apical; lâmina obovada, oblanceolada, longamente oblanceolada, margem inteira; nervura mediana muito proeminente. Inflorescência em panículas de curtas a longas, corimbosas, muito ramificadas, terminais, pedúnculo e ramificações espessos, avermelhados e quando $\operatorname{secos}^{*}$ rachados no sentido longitudinal. Flores de alvas a violáceas, pequenas, até $6 \mathrm{~mm}$ de comprimento, hermafroditas, pentâmeras, actinomorfas, pediceladas; cálice cupular, coriáceo, muito curtamente 5-dentado; pétalas 5 , oblongas, coriáceas, livres, barbadas por dentro abaixo da metade, inflexas no ápice, valvares na prefloração; estames 5, livres, todos férteis, inseridos no disco, filetes espessos, anteras oblongas, dorsifixas, conectivo dilatado; disco reduzido a ginóforo, levemente 5-1o. bado; ovário oval, 5-locular, 2 óvulos por lóculo, superpostos (alguns arbortivos), estileta cônico, estígma simples, muito pequeno. Fruto oval, drupáceo, 5-locular; lóculo dividido em dois por um falso septo transversal incompleto; sementes 2 , oblongas, superpostas, negras, lisas.

3 espécies ocorrem no Estado do Amazonas.

Espécie típica: $H$. brasiliensis Vandelli ey A. P. DC. 
DISTRIBUIÇÃo - Do sudeste do Brasil passando pelo Nordeste, Centro Oeste e Amazônia, até a República da Guiana e Colômbia.

O gênero Hortia difere de todos os outros gêneros da familia, entre vários caracteres, por apresentar principalmente fruto drupáceo.

\section{CHAVE PARA A DETERMINAÇÃO}

ESPECIES DE HORTIA

1. Folhas rígidas alcançando até ca. de $125 \mathrm{~cm}$ de comprimento e $20,5 \mathrm{~cm}$ de largura; lâmina boinoso-venulosa, glabérrima e brilhante por cıma e densamente pilosa por baixo; rede de nervuras mais conspícua; flores de alvas a violáceas.

$$
\text { H. superba (7. 3.) }
$$

1. Folhas coriáceas alcançando até ca. de $80 \mathrm{~cm}$ de comprimento e $8 \mathrm{~cm}$ de largura; iamina plana, glabra em ambos os lados; rèce de nervuras menos conspícua; flores de róseas a escarlates.

2. Foınas até ca. de $80 \mathrm{~cm}$ de comprimento; nervuras secundárias imersas por cima e planas por baixo; rêde menor de nervuras imersa em ambos os lados; inflorescência longa, até ca. de $26 \mathrm{~cm}$ de comprimento, botões florais globosos e flores róseas.

$$
\text { H. longifolia (7. 2.) }
$$

2. Folhas até ca. de $25 \mathrm{~cm}$ de comprimento; nervuras secundárias planas por cima e promínulas por baixo; rêde menor de nervuras imersa por cima e promínula por baixo; inflorescência curta, até ca. de $9 \mathrm{~cm}$ de comprimento, botões florais ovados e flores escarlates.

$$
\text { H. coccinea (7. I.) }
$$

7. 1. Hortia coccinea Spruce ex Engler, in Mart. Fl. Brás. 12 (2): 183. 1874; Cowan, Mem. N. Y. Bot. Gard. 14 (3): 4. 1967. Foto 13.

Arbusto a árvore pequena com raminhos densamente "folhosos. Folhas coriáceas, glabérrimas, até ca. de $25 \mathrm{~cm}$ de comprimento e $9 \mathrm{~cm}$ de largura; pecíolo subcilíndrico, mais ou menos delgado, ca. de $3,5 \mathrm{~cm}$ de comprimento e $4 \mathrm{~mm}$ de espessura; lâmina obovada, longamente oblanceolada ou oblanceolada, atenuada para a base e pouco aguda, obtusa, retusa ou emarginada no ápice, brilhante por cima e pouco opaca por baixo, margem subcrenada; nervura mediana saliente por cima e fortemente saliente por baixo; nervuras secundárias planas por cima e promínulas por baixo. inflorescência em panículas terminais, corimbosas, curtas, ca. de $9 \mathrm{~cm}$ de comprimento; ramificações curtas $(2-3 \mathrm{~cm}$ de comprimento), angulosas, glabras, avermelhadas, paucifloras, botões florais ovados. Flores escarlates; cálice carnoso, lacínios côncavos, curtos, subagudos; pétalas oblongas, coriáceas, densamente vermelho-barbadas na metade inferior; disco suburceolado, levemente 5-lobado; ovário ovado-globoso, parcialmente envolvido pelo disco; estilete vermelho, coroado. Fruto drupáceo.

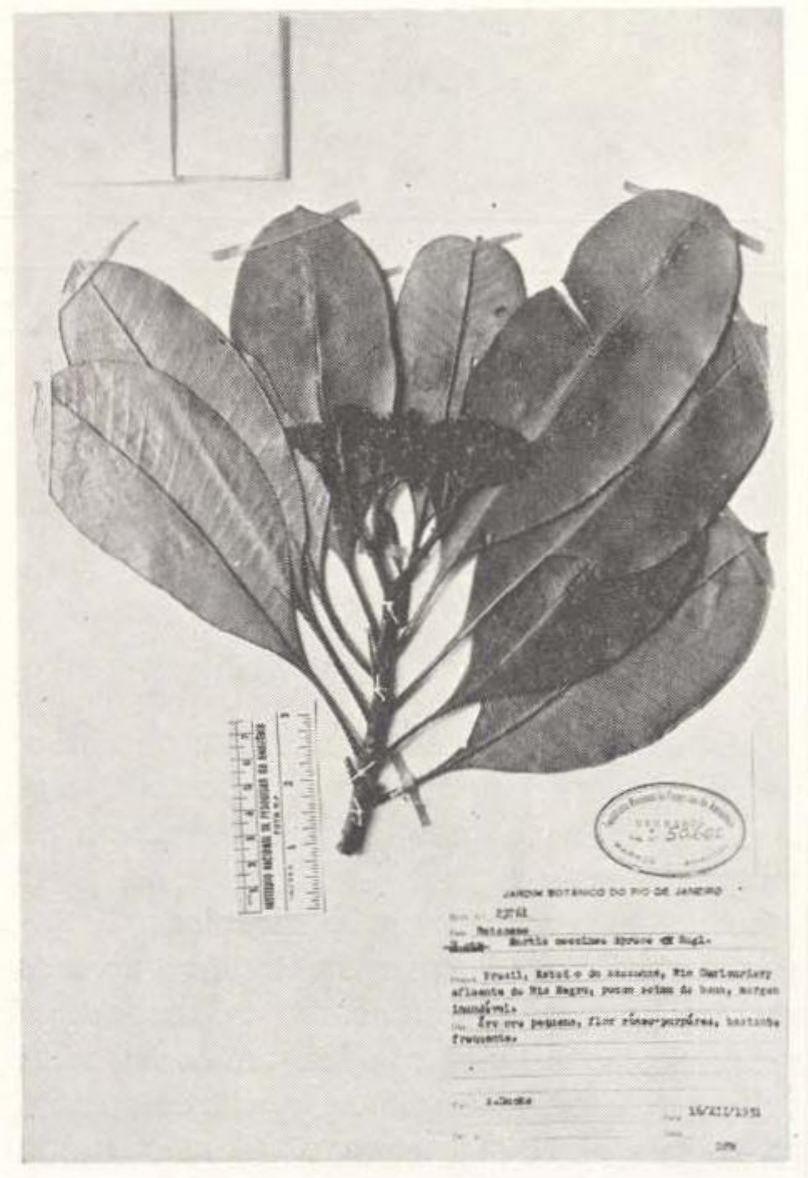

Foto 13. Hortia coccinea Spr. ex Engl. Ducke INPA 50602 (RB 23761). 
'TIPOS - Spruce 2006. Brasil. Amazonas, Uanauaca, entre Barcelos e São Gabriel da Cachoeira, rio Negro, fl (holótipo B, peráido; isótipos: MG 19457, K, NY; foto isótipo: NY).

JistribuIÇÃo - Do sul da Venezuela, Territorio Amazonas, rio Pacimoni ao norte do Brasil, Estado do Amazonas, região do alto rio Negro, até a boca do rio Curicuriari e a locali dade de Uanauaca, abaixo de São Gabriel da Cachoeira. Habita em terrenos rochosos da margem de rios e em mata que margeia as campinas próximas de rios. Flores em março e dezembro e frutos em março. BRASIL. Amazonas: Ducke RB $23761 \mathrm{fl}$ (RB, INPA 50.602); Fróes $27916 \mathrm{fl}$ (IAN); $28039 \mathrm{fr}$ (IAN). Fig. 7 .

Hortia coccinea difere de $H$. superba e $H$. longifolia, entre diversos caracteres, por apresentar principalmente folhas bem menores, pecíolos longos, delgados, inflorescência curta e flores escarlates.

\section{2. Hortia Iongifolia Spruce ex Engler, in} Mart. FI. Bras. 12 (2): 184. 1874; Ducke, Arch. Jard. Bot. Rio de Janeiro 3: 182. 1922; Cowan, Mem. N. Y. Bot Gard. 14 (3): 4. 1967. Fotos 14, 15 e 16 .

Hortia duckei Huber, Bol. Mus. Par. 5:424. 1909. Tipo: holótipo MG, n.v.).

Arbusto grande a árvore mediana até ca. de $15 \mathrm{~m}$ de altura. Folhas coriáceas, eretas, glabérrimas, $40-80 \mathrm{~cm}$ de comprimento e $6-8 \mathrm{~cm}$ de largura na região apical; lâmina longamente obovada ou oblanceolada, levemente brilhante por cima e opaca por baixo, decurrente pelo pecíolo até quase a base, aguda ou obtusa no ápice; nervura mediana pouco saliente por cima e fortemente saliente por baixo; rede menor de nervuras imersa em ambos os lados. Inflorescência em panículas corimbosas, muito ramificadas, multifloras, ca. de $26 \mathrm{~cm}$ de comprimento; ramificações angulosas e comprimidas, vermelhas; botões florais globosos. Flores róseas, pequenas; cálice cupular, lacínios" obtusos de prefloração imbricada; pétalas oblongas, coriáceas. Fruto drupáceo com a polpa fétida.

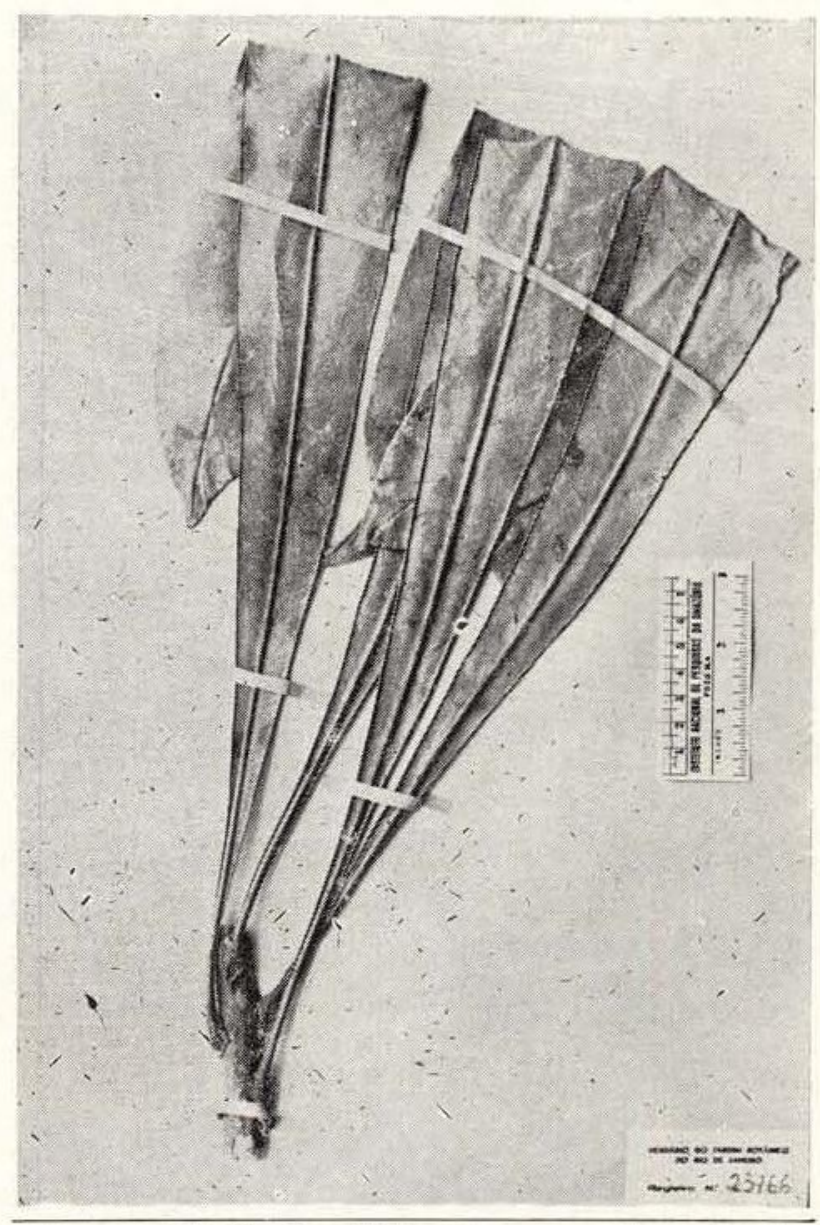

Foto 14. Hortia longifolia Spr. ex Engl Ducke RB 23766 .

TrPos - Spruce 1484. Brasil. Amazonas, Manaus, $\mathrm{fl}$ (holótipo: $\mathrm{B}$, perdido; isótipos: MG 19456, K, NY; foto isótipo: NY).

DISTRIBUIÇÃo - Da parte oriental do Amazonas à parte ocidental do Pará, na Amazônia Central. Habita em mata primária ou secundária fechada de terra firme ou em campina. Flores de junho a agosto e frutos em outubronovembro. BRASIL. Amazonas: Assumpção \& Coelho $78 \mathrm{fl}$ (INPA); Ducke MG $12522 \mathrm{fl}$ (MG); $R B 13617 \mathrm{fl}$ (RB); RB $23766 \mathrm{fl}$ (RB); Monteiro \& Mello INPA $50131 \mathrm{fl}$ (INPA); Rodrigues \& Almeida $2809 \mathrm{fl}$ (INPA); Schwacke $472 \mathrm{fl}(\mathrm{R})$. Pará: Assumpção \& Coelho $36 \mathrm{fr}$ (INPA) Black \& Ledoux $60-10600 \mathrm{fr}$ (IAN); Ducke MG 8379 fl (MG, INPA 12464); Egle: 845 \& Raimundo $\mathrm{fl}$ (MG, IAN); Fróes $31261 \mathrm{fr}$ (IAN); $33900 \mathrm{fl}$ (IAN). Fig. 7. 


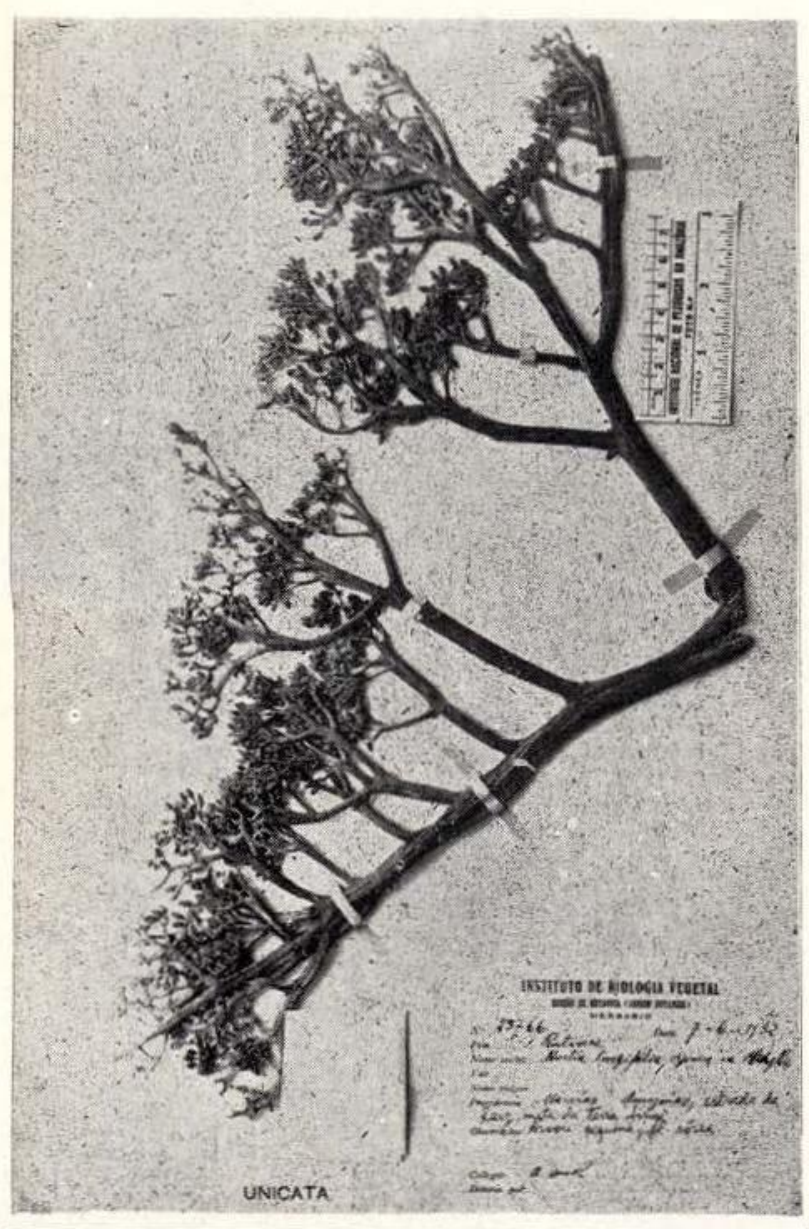

Foto 15. Hortia longifolia Spr. ex Engl. Ducke RB 23766.

Hortia longifolia tem uma certa afinidade com $H$. coccinea, porém difere desta por apresentar principalmente folhas bem maiores, nervuras secundárias imersas por cima e planas por baixo, rêde menor de nervuras imersa em ambas as faces, inflorescência maior e flores róseas.

\section{3. Hortia superba Ducke, Arch. Inst. Biol.} Veg. 1: 207. 1935; Tropical Woods 43: 21. 1935. Fotos 17 e 18.

Árvore mediana até $20 \mathrm{~m}$ de altura e $30 \mathrm{~cm}$ de diâmetro do fuste (DAP). Folhas grandes, largas, rígidas, até ca. de $125 \mathrm{~cm}$ de comprimento e $20,5 \mathrm{~cm}$ de largura; lâmina longamente obovada ou "oblanceolada, bolhoso-venulosa, glabérrima e brilhante por cima e densa e longamente pilosa por baixo, decurrente até a base do pecíolo, ápice agudo ou obtuso, curtamente acuminado; nervura mediana muito prceminente por baixo; nervuras secundárias $\mathrm{e}$ rêde menor de nervuras promínulas por cima e proeminentes por baixo. Inflorescência em panículas grandes, até ca. de $90 \mathrm{~cm}$ de comprimento e de largura, com as últimas ramificações e pedicelos muito delgados; botões florais avermelhados. Flores de alvas a violáceas; cálice cupular, 1-2mm de altura, lacínios curtos, imbricados na prefloração; pétalas oblongas, coriáceas. Fruto drupáceo, alaranjado, grande, ca. de $6 \mathrm{~cm}$ de comprimento e $4,2 \mathrm{~cm}$ de largura.

TIPO - Ducke $s / n$ Brasil Amazonas, Manaus, estrada do Aleixo, fl (holótipo $R B$ 23767).

DISTRIBUIÇÃo - Desde a parte oriental do Amazonas, na Amazônia Central, até o Território do Amapá e Pará, na Amazônia Oriental

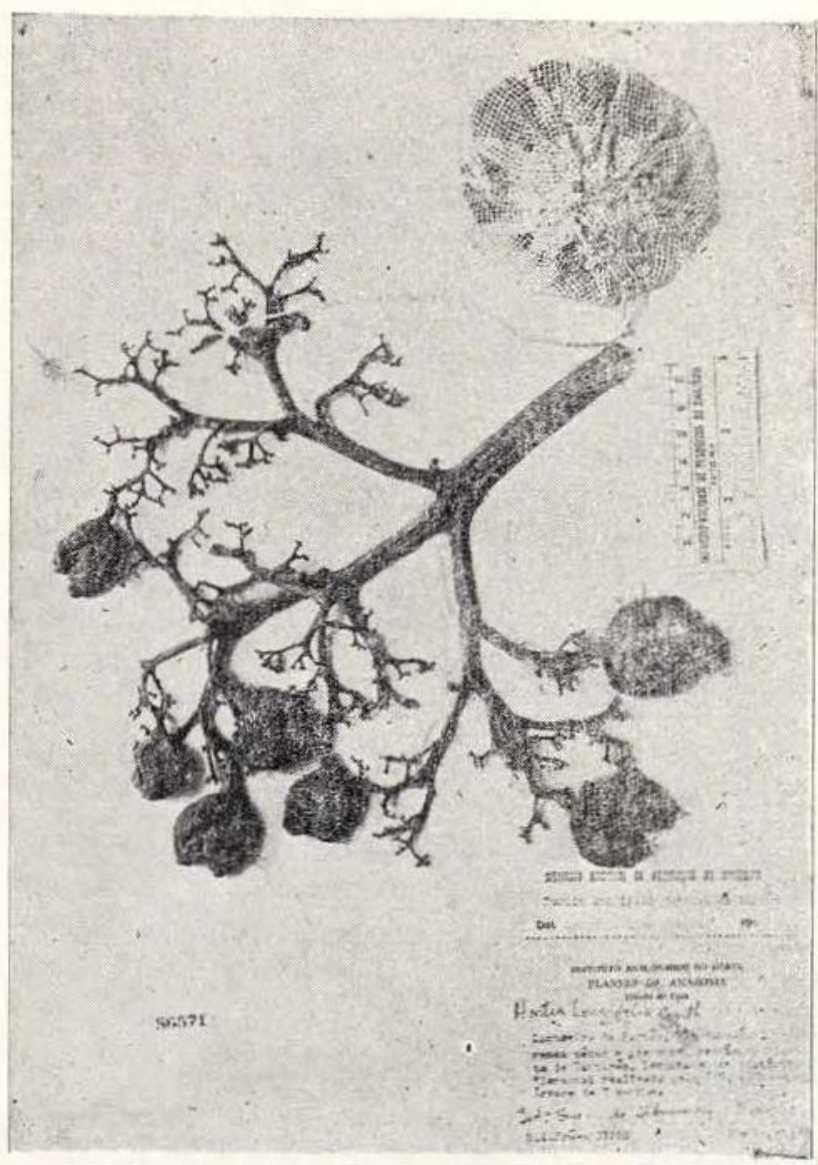

Foto 16. Hortia longifolia Spr. ex Engl. Fróes 31261 (IAN). 
atlântica. Habita em mata primária de terra úmida, argilosa, humosa e às vezes em igapó. Flores de março a novembro e frutos de maio a dezembro. BRASIL. Amazonas: Albuquerque INPA $5529 \mathrm{fl}$ (INPA, IAN 94763); Ducke $445 \mathrm{fr}$ (IAN); $455 \mathrm{fl}$ (IAN, R); Fróes $33785 \mathrm{fl}$ (IAN); Loureiro et al. INPA $35776 \mathrm{fl}$ e fr (INPA); Rodrigues $6711 \mathrm{fl}$ (INPA); $8146 \mathrm{fr}$ (INPA); Silva et al. $785 \mathrm{fl}$ e fr (INPA). Pará: Prance et al. $1559 \mathrm{fl}$ (IAN). Território do Amapá: Bastos $235 \mathrm{fl}$ (IAN). Fig. 7.

NOME VULGAR - BRASIL. Pau maríim (Illha do Breu, rios Pacajá e Muirapiranga, Pará) .

Segundo Ducke (1935), Hortia superba é próxima de $H$. excelsa do Pará, região de Gurupá, todavia, difere desta pelas folhas rigidamente coriáceas, bolhoso-venulosas por cima, mais longamente pilosa por baixo principal-

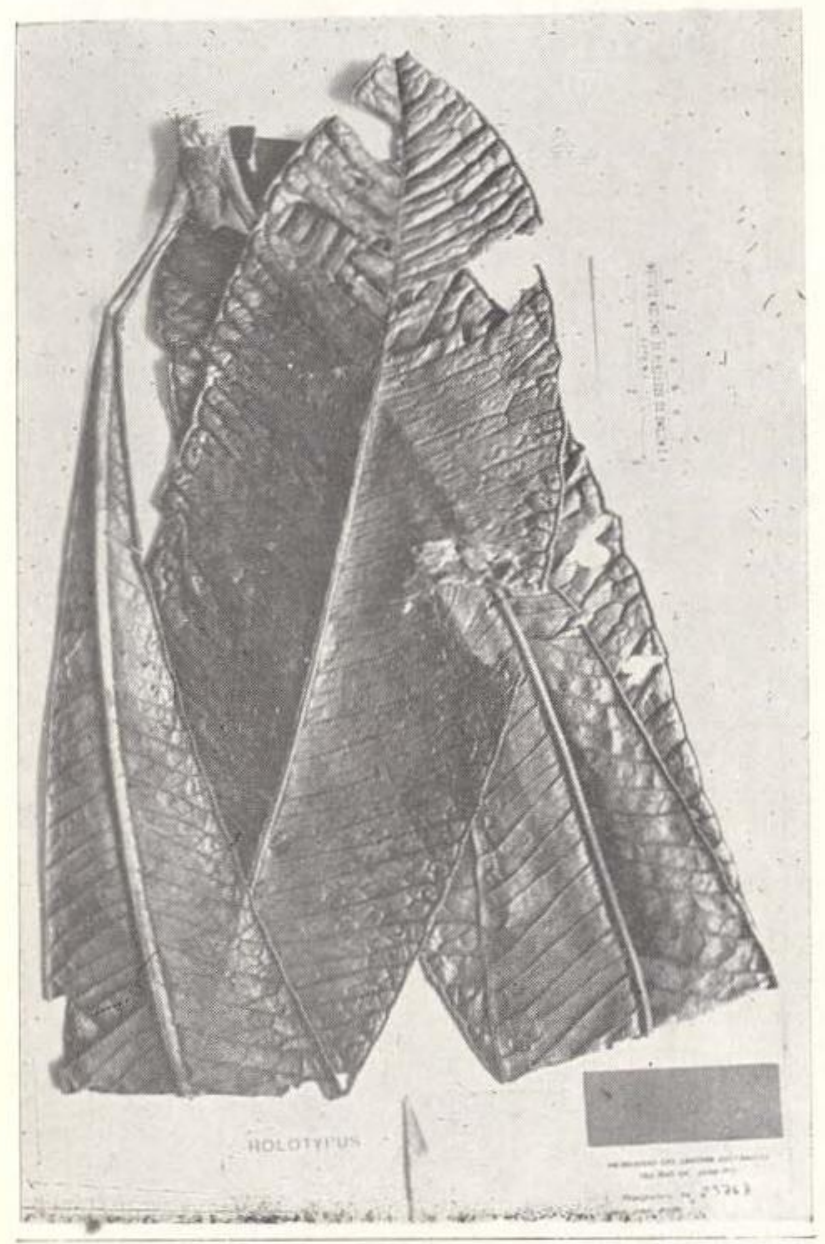

Foto 17. Hortia superba Ducke. Ducke RB 23767, holótipo.

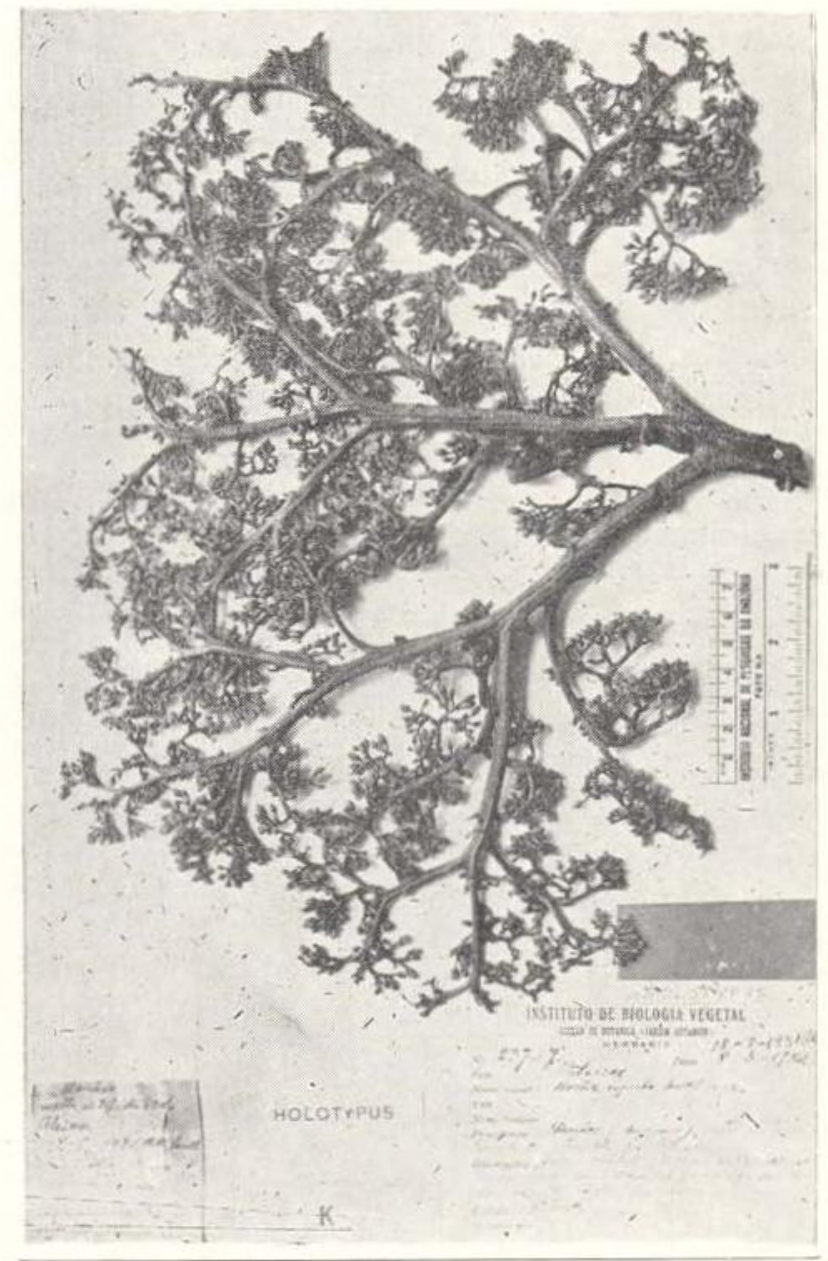

Foto 18. Hortia superba Ducke. Ducke RB 23767, holótipo.

mente próximo às nervuras, panículas com as últimas ramificações muito finas e flores menores, como as de $H$. longifolia. $H$. superba separa-se de $H$. coccinea e $H$. longifolia, entre outros caracteres, por apresentar principalmente folhas rígidas, lâmina bolhoso-venulose. por cima e densa e longamente pilosa por baixo.

8. Leptothyrsa Hooker f., in Benth. \& Hook. Gen. PI. 1: 284. 1867; Engler, in Mart. FI. Bras. 12 (2): 129. 1874; Cowan, Mem. N. Y. Bot. Gard. 14 (3) : 5. 1967.

Arvoreta simples não ramificada; casca branca. Folhas simples, espiraladas, com internós muito curtos, aglomeradas no ápice do coule, membranáceas, grandes, glabérrimas, subsésseis ou espessas na base; lâmina es- 
treitamente obovado-lanceolada, bruscamente para a base longamente atenuado-cuneada, acuminada, acúmen emarginado, da metade para a base longamente atenuado-cuneada, margem inteira. Inflorescência em panículas racemosas estreitas de tirsos finos, pedúnculo mais longo que a porção florífera, subcilíndrico. Flores alvas, pequenas, hermafroditas, tetrâmeras, actinomorfas; cálice cupular, indistintamente 4-dentado; corola tubular, de 4 pétalas, 4-lobada, lobos valvares na prefloração; estames 4, livres, todos férteis, inseridos na base do disco, filetes filiformes, anteras lineares, mais longas que os filetes; disco urceolado, inteiro; ovário deprimido envolvido pelo disco, 4-locular, estiletes 4, soldados, estígma 4-lobado. Fruto 1-2 cocas conchiformes, bivalvas; semente 1 , mais ou menos conóide, finamente crustácea.

Gênero monotípico cuja espécie ocorre no Estado do Amazonas.
Espécie típica: L. sprucei Hooker $f$.

DISTRIBUIÇÃo - Das terras baixas do Peru e da Colômbia até o noroeste do Estado do Amazonas (alto rio Negro), Brasil.

O gênero Leptothyrsa difere dos outros gêneros da família por apresentar, entre outros caracteres, principalmente a inflorescência em panículas racemosas de tirsos finos.

Loptcthyrsa sprucei Hooker f., in Benth. \& Hook. Gen. PI. 1: 284. 1867; Engler, in Mart. FI. Bras. 12 (2): 131. 1874; Ducke, Arch. Jard. Bot. Rio de Janeiro 5: 144. 1930; Cowan, Mem. N. Y. Bot. Gard. 14 (3): 5. 1967. Foto 19.

Arvoreta simples de 1-2,5 $\mathrm{m}$ de altura, coroada pelas folhas. Folhas membranáceas, $30-50 \mathrm{~cm}$ de comprimento e $5-9 \mathrm{~cm}$ de largura;

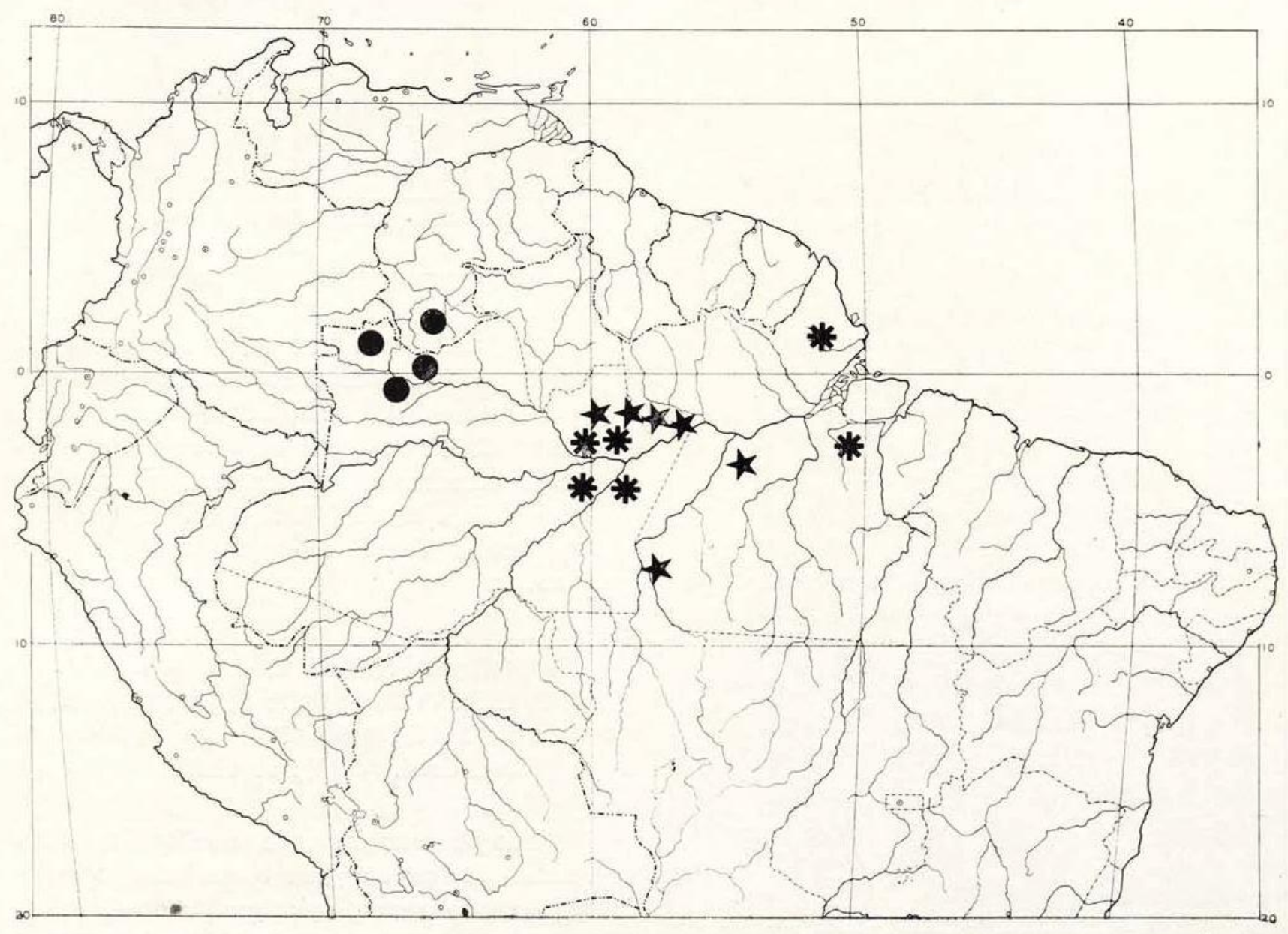

Fig. 7. Distribuição geográfica de Hortia coccinea, $*$ H. longifolia $e *$ H. superba. 


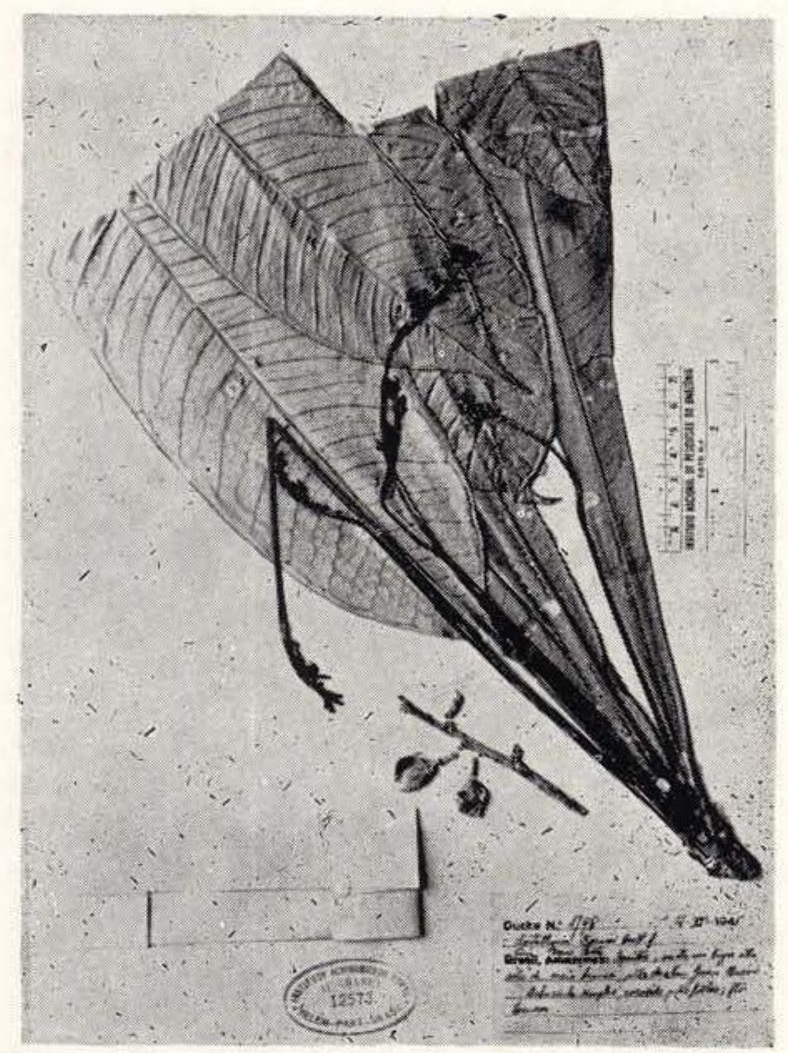

Foto 19. Leptothyrsa sprucei Hook. f. Ducke 1798 (IAN).

lâmina estreitamente obovado-lanceolada, brus camente acuminada no ápice, acúmen emarginado, longamente atenuado-cuneada para a base, esverdeadas por cima e pardas por baixo, margem inteira; rêde de nervuras ruiva por baixo. Inflorescência em panículas racemo. sas, axilares, delgadas, glabérrimas, $30-40 \mathrm{~cm}$. de comprimento, pedúnculo subcilíndrico, ramificações floríferas de 3-5 flores. Flores alvas, ca. de $18 \mathrm{~mm}$ de comprimento; cálice ca. de $1,5 \mathrm{~mm}$ de altura; pétalas tenras; estames com anteras alvas, $3 \mathrm{~mm}$ de comprimento. Fruto coca rombóide-conchiforme, castanho-clara, diâmetro maior $1 \mathrm{~cm}$; semente conóide, aguda, $8-9 \mathrm{~mm}$ de comprimento, testa parda, umbílico negro.

TIPO - Spruce 2596. Brasil. Amazonas, rio Vaupés, Panuré, $\mathrm{fl}$ e $\mathrm{fr}$ (holótipo: $\mathrm{K}, n$. v.).

DISTRIBUIÇÃo - Das regiões baixas da Colồmbia e do Peru até o alto rio Negro (rio
Vaupés), no Estado do Amazonas, Brasil. Habita em matas ou savanas, provavelmente comum em solos de areia branca. Flores em novembro e frutos em maio. BRASIL. Amazonas: L. Coelho $45 \mathrm{fr}$ (INPA); Pires 1083 est (IAN). COLÔMBIA. Schultes \& Black 46-364 fI (IAN). PERU. Departamento Loreto: Ducke $1798 \mathrm{fl}$ (IAN). Fig. 8.

Leptothyrsa sprucei é até o momento a única espécie descrita para o gênero Leptothyrsa e lembra Adiscanthus fusciflorus pelas folhas e pelos frutos.

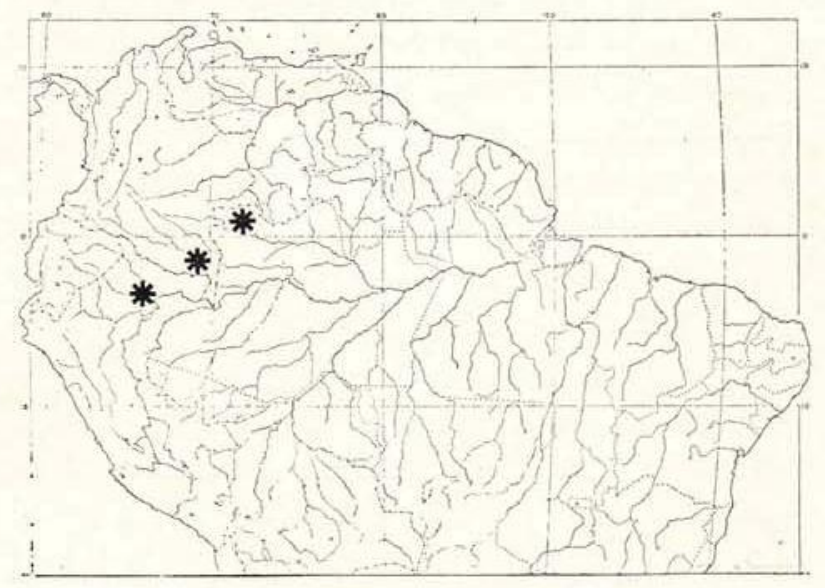

Fig. 8. Distribuição geográfica de * Leptothyrsa sprucei.

9. Monnieria Loefling, Iter. Hispanicum 197. 1758; corr. Linnaeus, Syst. Nat. ed. 10, 2: 1759; Engler, in Mart. Fl. Bras. 12 (2) : 127. 1874; Cowan, Mem. N. Y. Bot. Gard. 14 (3): 14. 1967.

Aubletia Rich., Pers. Syn. 2:638. 1807. (*)

Ertela Adans., Fam. 2: 358. 1763. (*)

Plantas herbáceas anuais. Folhas opostas digito-trifolioladas, tenras; folíolos oblongoelíticos, atenuados para o ápice, inteiros ou subcrenados. Inflorescência dicasial com dois rácemos cincinóides e uma flor terminal no ápice do pedúnculo. Flores alvas, hermafroditas, pentâmeras, zigomorfas; cálice de 5 sépalas muito desiguais na forma e no tamanho, 2 externas foliáceas, imbricadas na prefloração; corola de 5 pétalas unidas em um tubo reto. bilabiada, lacínias desiguais, as superiores bi-

$\left({ }^{*}\right)$ - Sinônimos citados por Engler (1874) e Cowan (1967). 
partidas; estames 5 , adnatos à corola até a abertura do tubo, epipétalos, 2 férteis, situados do lado do lábio inferior, filetes achatados, concrescidos, barbados abaixo das anteras; antera pequena, oblongo-lanceolada, não apendiculada; estaminódios situados do lado do lábio superior, subulados, barbados a altura da metade; disco obliquamente urceolado ou escamiforme; ovário 5-locular, lóculos unidos apenas pelo estilete, óvulos 2 por lóculo, superpostos, estilete curto, estígma capitado. Fruto 1-5 cocas muito pequenas, conchiformes, dorso e ventralmente carinadas, bivalvas; semente 1, levemente reniforme, ventralmente provida de rostelos, agudamente tuberculadomuricada, testa parda.

I espécie do Estado do Amazonas.

Espécie típica: $M$. trifolia Loefling.

DISTRIBUIÇÃo - Do sul do Brasil ao México e Estados Unidos (Flórida).

O gênero Monnieria separa-se dos outros gêneros por apresentar principalmente plantas herbáceas com inflorescência dicasial e sépalas livres muito desiguais na forma e no tamanho.

Monnieria trifolia Loefling, Iter. Hispanicum 197. 1758; Linnaeus, Syst. Nat. ed. 10, 2: 1153. 1759; Engler, in Mart. Fl. Bras. 12 (2): 127. 1874; Lemée, Fl. Gui. Franç. 10 : 184-185. 1952; Cowan, Mem. N. Y. Bot. Gard. 14 (3) : 14. 1967. Foto 20.

Aubletia trifoliata Rich., Pers. Syn. 2:638. 1807. (*)

Erva anual de caule ereto, lenhoso na base, ramos dicótomos ou tricótomos. Folhas opostas, trifolioladas, finas, com glândulas translúcidas muito pequenas, esparsamente cobertas de pêlos rígidos, adpressos; folíolos oblongoelíticos, desiguais, inteiros, atenuados para o ápice, o terminal maior, os laterais oblíquos, sésseis; lâmina foliolar de margem não ciliada. Inflorescência em dicásio, com ramificações racemosas de 3-5 flores. Flores alvas, eretas, curtamente pediceladas; cálice com 2 sépalas externas, desiguais, foliáceas, ovadas $\mathrm{cu}$ ovado-oblongas ou obovadas, as internas muito pequenes; corola de tubo reto com o

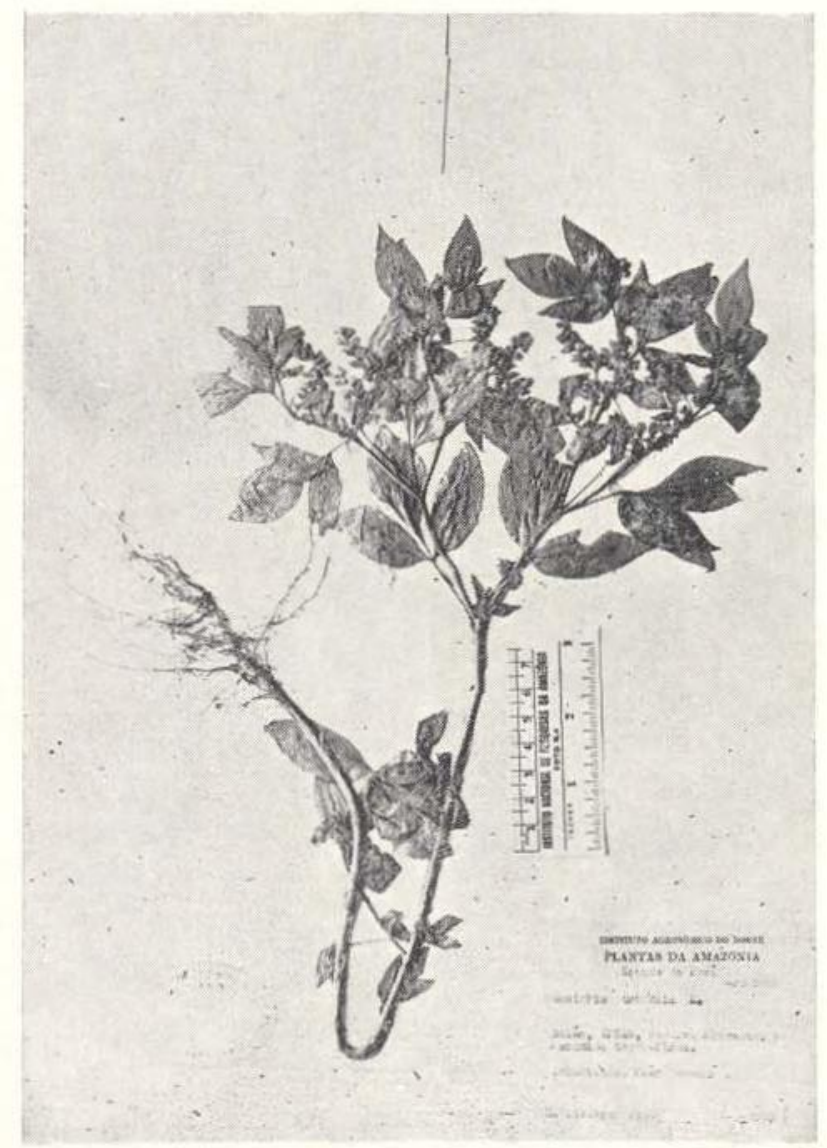

Foto 20. Monnieria trifolia Loefl. Oliveira 2390 (IAN).

limbo bilabiado, lábio inferior subquadradoemarginado, o superior bipartido com lacínias divergentes, bífidas; estames 5, 2 férteis, filetes subulados, barbados a aitura da metade, anteras oblongo-lanceoladas; disco obliquamente urceolado ou escamiforme; ovário deprimido-globoso, estilete curto, estígma capitado. Fruto freqüentemente 4-5 cocas membranáceas, ovado-comprimidas, muito pequenas, dorso e ventralmente carinadas, curtamente apiculadas, cobertas de giândulas avermelhadas; semente 1 , sub-reniforme, ventralmente rostelada, tuberculado-muricada.

$$
\text { TIPos - (não localizados). }
$$

DISTRIBUIÇÃo - Do México ao sul do Brasil. Habita principalmente como erva daninha em áreas abertas de sombra parcial em margens de estradas, rios, lagos, em mata secundária baixa, clareiras de agricultura, ao redor

(*) - Sinônimo mencionado por Engler (1874). 
de vilas e até em mata primária densa, úmida. Colhida com flores e frutos de janeiro a dezembro. BRASIL. Amazonas: Castellanos INPA $27550 \mathrm{fr}$ (INPA); Coelho \& Coelho $38 \mathrm{fl}$ e $\mathrm{fr}$ (INPA); Duarte $7128 \mathrm{fl}$ e fr (RB); Duarte \& Coelho $9847 \mathrm{fr}$ (INPA); Maas \& Maas $470 \mathrm{fl}$ (INPA); Oliveira $2136 \mathrm{fl}$ e $\mathrm{fr}$ (IAN); $3005 \mathrm{fl}$ (IAN); Prance et al. $8013 \mathrm{fl}$ (INPA); $13720 \mathrm{fl}$ (INPA); $14536 \mathrm{fl}$ (INPA, MG) : $15273 \mathrm{fr}$ (INPA); $20171 \mathrm{fl}$ e $\mathrm{fr}$ (INPA); $21785 \mathrm{fl}$ (INPA); $22002 \mathrm{fl}$ (INPA): $22042 \mathrm{fl}$ (INPA); Rodrigues \& Lima $8111 \mathrm{fl}$ (INPA); Silva et al. $1753 \mathrm{fr}$ (INPA); Ule $6141 \mathrm{fl}$ (MG). Pará: Archer $7933 \mathrm{fl} \mathrm{e} \mathrm{fr}$ (IAN); $8090 \mathrm{fl}$ e fr (IAN); Baker $435 \mathrm{fr}$ (MG); Cavalcante $2608 \mathrm{fl}$ (MG); Cavalcante 2209 \& Austin $4080 \mathrm{fl}$ (MG); Ducke MG $10733 \mathrm{fr}$ (MG); Kuhlmann 488, 480 e $490 \mathrm{fr}$ (R); M. Silva $1120 \mathrm{fr}$ (MG); N. T. Silva IAN $117511 \mathrm{fl}$ e $\mathrm{fr}$ (IAN); Oliveira $1864 \mathrm{fl} \mathrm{e} \mathrm{fr}$ (IAN); $2590 \mathrm{fl}$ e fr (IAN); Pires \& Black $365 \mathrm{fl}$ e fr (IAN); Prance, Pennington \& Silva 1311 $\mathrm{fl}$ (IAN); Pran- ce et al. $22487 \mathrm{fr}$ (INPA). Território do Amapá: Egler \& Erwin $46397 \mathrm{fl}$ (IAN); Emmerich 629 \& Andrade $666 \mathrm{fr}(\mathrm{R})$; Fróes \& Black $27338 \mathrm{fr}$ (IAN); Irwin $48780 \mathrm{fr}$ (IAN); Irwin et al. 47943 $\mathrm{fle} \mathrm{fr}($ IAN); N. T. Silva $1518 \mathrm{fl}$ (IAN). Território de Rondônia: Prance et al. $8460 \mathrm{fl}$ (INPA); $8899 \mathrm{fl}$ (INPA). Território de Roraima: Kuhlmann $325 \mathrm{fr}$ (INPA); Prance et al. $4599 \mathrm{fl}$ e fr (INPA, IAN). COLÔMBIA. Intendência del Meta: Phillipson et al. $1459 \mathrm{fl}$ e fr (IAN); Smith \& Idrobo $1493 \mathrm{fl}$ e $\mathrm{fr}$ (IAN). VENEZUELA. Território Bolivar: Williams $12026 \mathrm{fr}$ (IAN). Fig. 9.

NOMES vULGares - Brasil. Aifavaca de cobra (Amazonas, Manaus); jaborandi do Pará, jaborandi de três folhas, pimenta de lagarta (Pará); alfavaca brava (Maranhão; Pará).

usos - Esta espécie, segundo LeCointe (1947), tem diversas aplicações na medicina caseira como tônica, diurética e sudorífica.

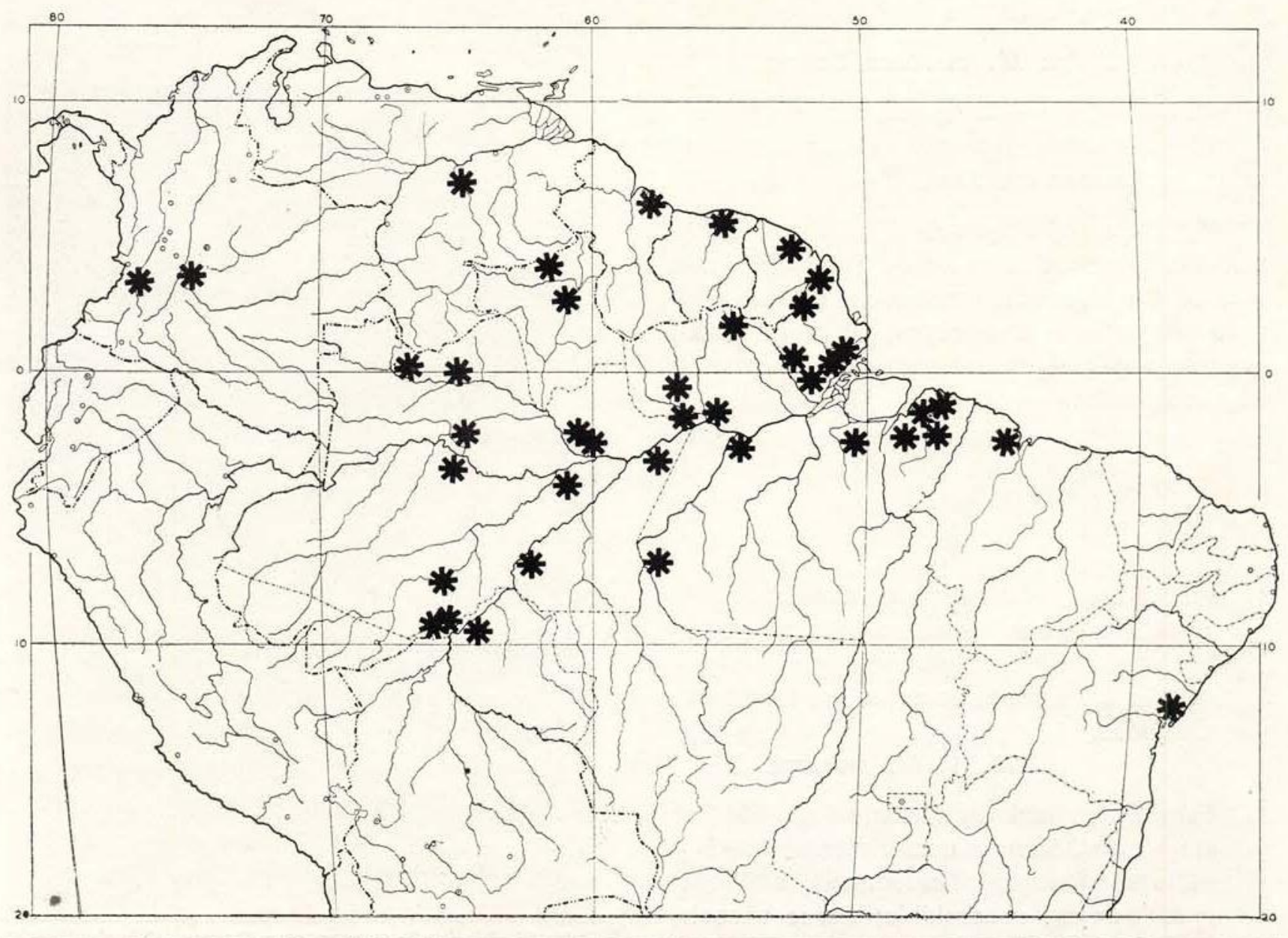

Fig. 9 Distribuição geográfica de * Monnieria trifolia. 
10. Myllanthus Cowan, Mem. N. Y. Bot. Gard. 10 (2): 34. 1960 e 14 (3): 7. 1967.

Arbustos a árvores medianas de ca. de $10 \mathrm{~m}$ de altura. Folhas opostas, trifolioladas, pecíolos curtos ou longos; folíolos oblongos ou elíticos. Inflorescência unilateralmente cincinóide-racemosa, caulifora ou ramiflora. Flores de verdes a alvas, pediceladas a sésseis, hermafroditas, pentâmeras, zigomorfas; sépalas 5 , livres, com lacínios imbricados; pé. talas 5 , muito imbricadas, desigualmente unidas em um tubo curvo; estames 4-5, 2 férteis, filetes adnatos ao tubo da corola, anteras apendiculadas na base, conectivo geralmente papiloso-glandular; disco cupular ou urceolado; ovário ovóide, 5-locular, lóculos unidos apenas pelo estilete, estígma 5-lobado. Fruto $1-5 \mathrm{co}-$ cas obovadas, conchiformes, deiscentes em 2 valvas; semente 1, globosa, elipsóide ou ovado-oblonga.

\section{2 espécies do Estado do Amazonas.}

Espécie típica: $M$. maroana Cowan.

DISTRIBUição - Do sul da Venezuela (Territorio Amazonas) ao norte do Brasil, nos Estados do Amazonas e Pará.

Myllanthus distingue-se dos demais gêneros, entre outros caracteres, principalmente pela corola arqueada, embora se associe filogeneticamente com o gênero Ravenia, onde algumas espécies apresentam corola sigmóide ou subsigmóide.

CHAVE PARA A DETERMINAÇÃO

DAS ESPÉCIES DE MYLLANTHUS

1. Folhas com pecíolos longos, canalicuiados. 10-12 cm de comprimento; folíolos oblongos, peciolulados; inflorescência caulifora, não claramente escorpióide; flores pe diceladas.

\section{1. M. maroana}

1. Folhas com pecíolos curtos, subcilíndricos; até ca. de $3,5 \mathrm{~cm}$ de comprimento; folíolo elíticos, sésseis; inflorescência ramiflora, pseudo-åxilar, escorpióide; flores sésseis ou subsésseis.

10. 2. M. ulei
10. I. Myllanthus maroana Cowan, Mem. N. Y. Bot. Gard. 10 (2): 35-37, fig. 22, a-d, 1960 e 14 (3): 7. 1967. Foto 21.

Arbustos a árvores até ca. de $8 \mathrm{~m}$ de altura. Folhas trifolioladas, pecíolos $10-12 \mathrm{~cm}$ de comprimento, canaliculados; folíolos peciolulados, oblanceolados a oblanceolado-oblongos, coriáceos, base cuneado-atenuada, ápice agudo, $25-45 \mathrm{~cm}$ de comprimento e $8-14 \mathrm{~cm}$ de largura, margem inteira. Inflorescência cauliflora, unilateralmente cincinóide-racemosa, $3-5 \mathrm{~cm}$ de comprimento, raque e flores curtamente malpiguiáceo-estrigulosos, pedicelos $4-6 \mathrm{~mm}$ de comprimento. Flores de esverdeadas a alvas; sépalas 5 , suborbiculares a orbiculares, cilio. ladas, 3-3,5 $\mathrm{mm}$ de comprimento; pétalas 5 , vilosas por dentro, desigualmente unidas, pétala abaxial unida ao tubo da corola em ca. de $4 \mathrm{~mm}$ de entensão com lacínia obtusa, as péta-

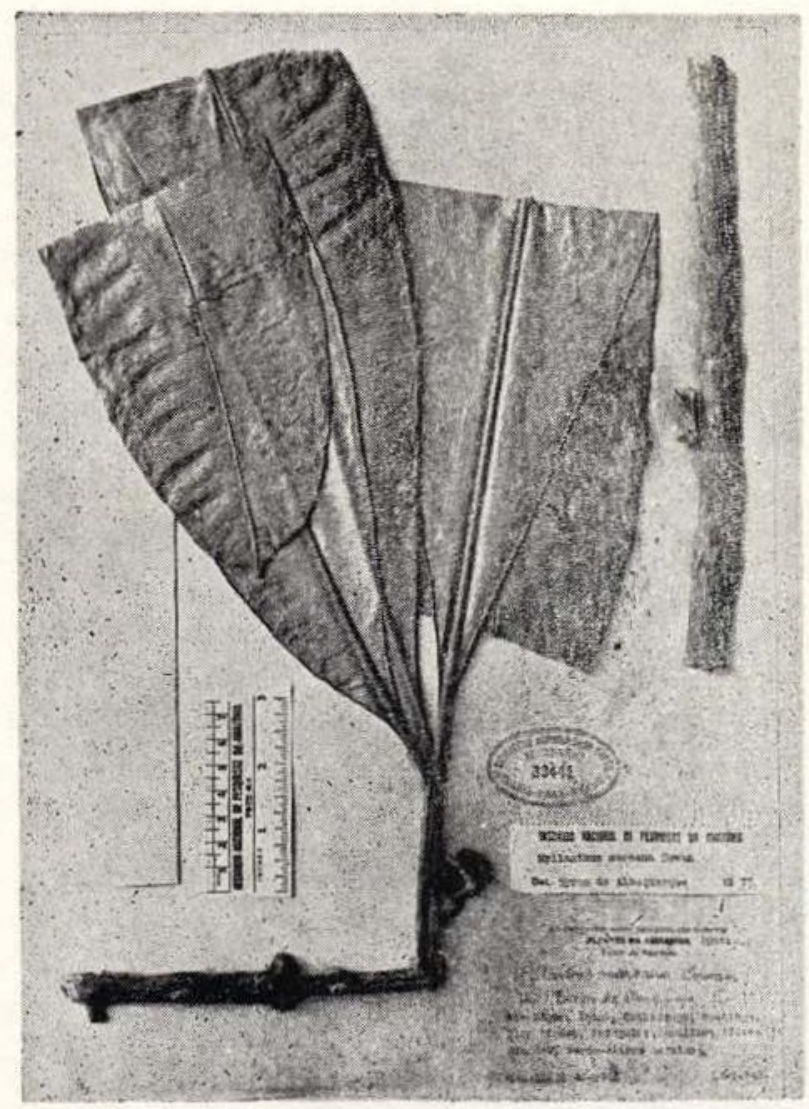

Foto 21. Myllanthus maroana Cowan. Black 48-2706 (IAN). 
las restantes unidas em um lábio quadrilobado, curvo, com lacínias oblongas, levemente cuculadas, de ápice arredondado; estames 4, 2 férteis, filetes alongado-oblanceolados, subulados no ápice, vilosos, anteras oblongas, com apêndices basais largamente flabelados, curvados para o ápice das anteras e papilosoglandulares; disco cupular, carnoso; ovário glabro, papiloso, estilete glabro. Fruto cocas oblongo-obovadas, deiscentes para o ápicc; semente 1 , ovado-oblonga.

'IIPO - Maguire, Wurdack \& Keith 41780. Venezuela. Amazonas, caminho para Guzman Blanco, 1-5 km suleste de Maroa, rio Guainia, fl (holótipo: US 2267414, n. v.).

DISTRIBUIÇÃo - Desde a região do rio Guainia, Territorio Amazonas, na Venezuela, até o rio Içana, afluente do alto rio Negro, Estado do Amazonas, Brasil. Habita em mata primária alta de terra firme baixa ou no sopé de elevações ou em campina. Flores em maio e outubro e frutos em outubro. BRASIL. Amazonas: Black $48-2706 \mathrm{fl}$ e $\mathrm{fr}$ (IAN); Pires 781 fl (INPA). Fig. 10.

Myllanthus maroana separa-se de M. ulsi por apresentar principalmente folíolos maiores, oblongos, inflorescência cauliflora, não claramente escorpióide, bem mais curta (3-5 $\mathrm{cm}$ de comprimento), disposta em par e flores pediceladas.

\section{2. Myllanthus ulei (Krause) Cowan, Mem.} N. Y. Bot. Gard. 10 (2): 37. $1960 \mathrm{e}$ 14 (3): 7. 1967. Foto 22.

Cusparia ulei Krause, Fedde, Repert. Nov. Sp. Regn. 2:26. 1906. Tipo. Ule 5382a. Brasil. Am? zonas, Manaus (holótipo B, perdido).

Arbustos a árvores até ca. de $10 \mathrm{~m}$ de altura, esparsamente ramificados. Folhas trifolioladas, pecíolos subcilíndricos, até ca. de $3,5 \mathrm{~cm}$ de comprimento; folíolos sésseis ou subsésseis, mais ou menos lanceolados ou elíticos, subcoriáceos, base atenuada, ápice acuminado, $7,3-36 \mathrm{~cm}$ de comprimento e até ca. de $10,4 \mathrm{~cm}$ de largura, margem inteira, raro levemente revoluta. Inflorescência ramiflora, clara e unilateralmente cincinóide-racemosa, pseudo-axilar, cimosas, até ca. de $24 \mathrm{~cm}$ de compri-

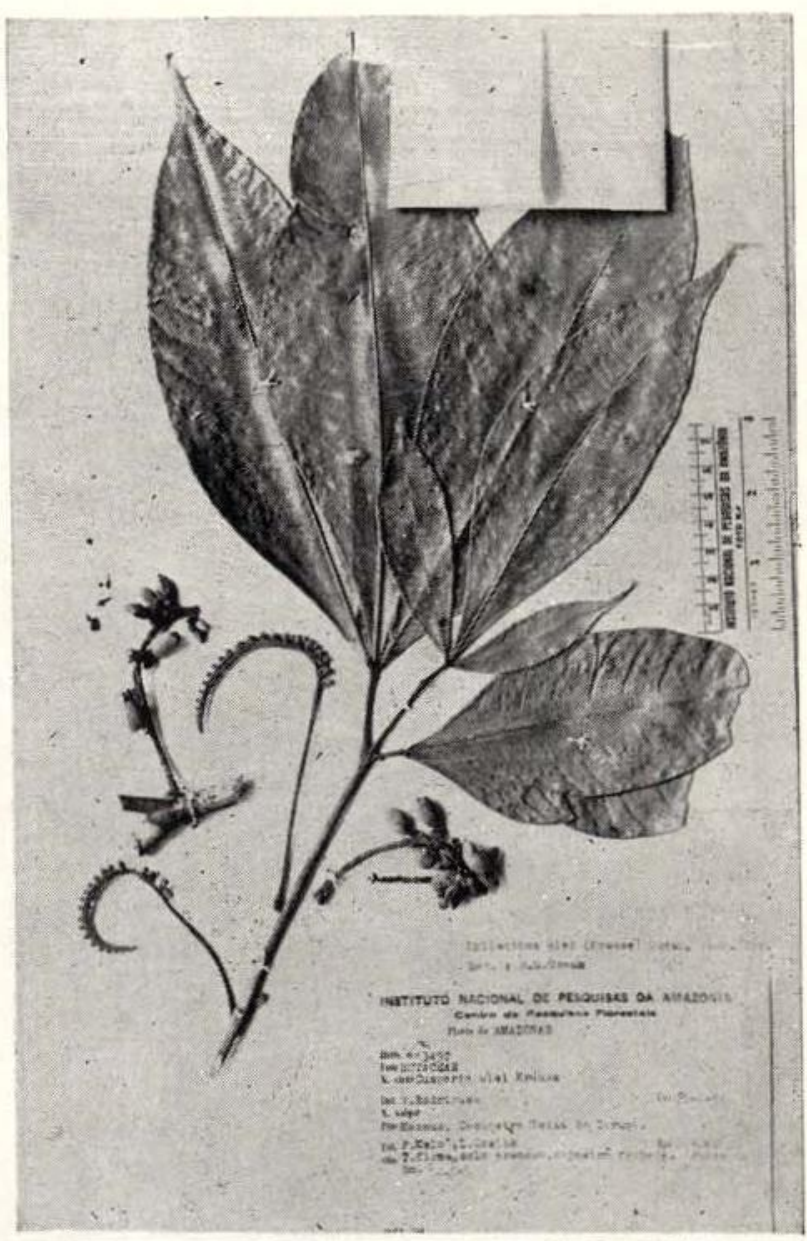

Foto 22. Myllanthus ulei (Krause) Cowan. Mello \& Coelho INPA 3492.

mento. Flores de esverdeadas a alvas, dísticas, sésseis ou subsésseis; sépalas 5 , largamente triangulares, subtruncadas, muito imbricadas, cilioladas na parte apical da margem; pétalas 5 , elíticas, densamente vilosas por fora; estames 5, 2 férteis, filetes adnatos na base com o tubo da corola, densamente barbados, anteras subagudas, comprimidas; disco urceolado, muito glanduloso na parte inferior; ovário incluso no disco, estígma pequeno, capitado. Fruto 1.5 cocas oblongo-obovadas, conchiformes, deiscentes para o ápice; semente globosa ou elipsóide.

TrPOS - Ule 5382a. Brasil. Amazonas. Manaus, $\mathrm{fl}$ e fr (holótipo B, perdido; foto holótipo: NY; isótipo; MG 5335).

DISTRIBUIÇÃo - Ocorre no Amazonas, desde o alto rio Negro (São Gabriel da Cachoeira) 


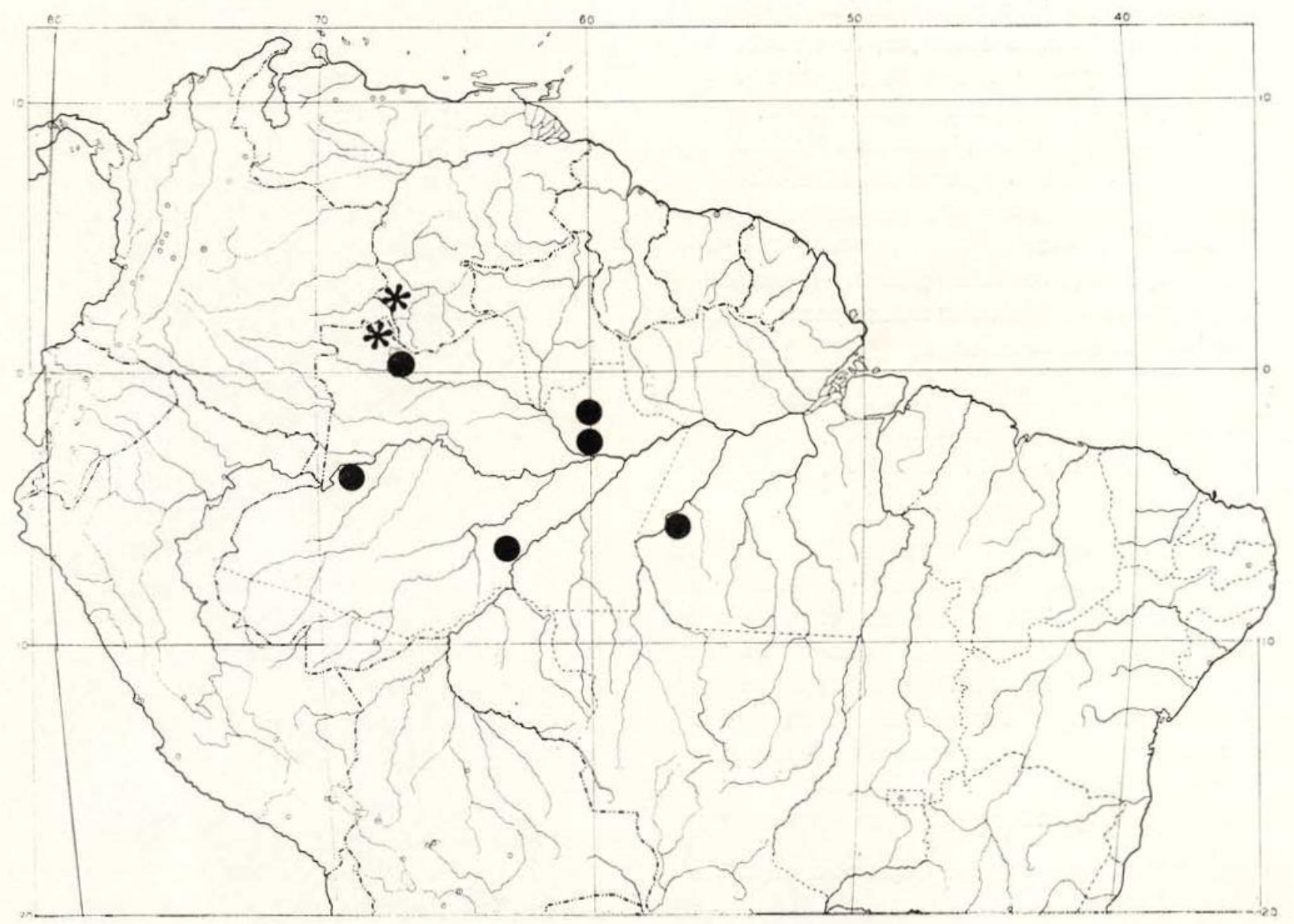

Fig. 10. Distribuição geográfica de $*$ Myllanthus maroana $€$

M. ulei.

e alto rio Solimões (Säo Paulo de Olivença) até o Pará, no rio Tapajós. Habita em mata primária de terra firme ou longo de rios ou igarapés ou em campina. Colhida com flores de fevereiro a dezembro e com frutos de fevereiro a outubro. BRASIL. Amazonas: Almeida INPA $734 \mathrm{fl}$ (INPA, IAN 110856): INPA $3602 \mathrm{fI}$ e fr (INPA); D. Coelho INPA $2268 \mathrm{fl}$ (INPA, IAN 110922); L. Coelho INPA $1662 \mathrm{fl}$ (INPA); Ducke RB $20478 \mathrm{fl}$ (RB); RB $24168 \mathrm{fr}$ (RB); $R B 35597 \mathrm{fl}$ (RB); Fróes $20734 \mathrm{fr}$ (IAN); 22144 fr (IAN); $34849 \mathrm{fr}$ (IAN); Maas \& Maas $490 \mathrm{fl}$ (INPA); Mello INPA $4122 \mathrm{fl}$ (INPA); Mello \& Coelho INPA $3492 \mathrm{fr}$ (INPA); Pena \& Silva 58 $\mathrm{fr}$ (IAN); Prance et al. $2247 \mathrm{fl}$ e $\mathrm{fr}$ (INPA), R, NY); 3177 (INPA); 4979 fr (INPA, MG); $23014 \mathrm{fl}$ e fr (INPA). Pará: Ducke RB $13614 \mathrm{fl}$ (RB). Fig. 10.
Myllanthus ulei difere de $M$. maroana principalmente pelos folíolos menores, elíticos, inflorescência ramiflora, claramente escorpióide, bem mais longa (até ca. de $24 \mathrm{~cm}$ de comprimento), solitária e flores sésseis ou subsésseis.

11. Nycticalanthus Ducke, Notizbl. Bot. Gart. Berlin 11: 341. 1932; Arch. Jard. Bot. Rio de Janeiro 6: 41-42. 1933.

Subarbusto a árvore pequena. Folhas grandes, alternas, trifolicladas, longamente pecioladas. Inflorescência em panículas terminais amplas, de cimeiras longamente pedunculadas. Flores grandes, bem alvas, hermafroditas, pentâmeras, zigomorfas, até ca. de $10 \mathrm{~cm}$ de comprimento; cálice tubuloso, alongado, curtamen- 
te 5-dentado, decíduo juntamente com as pétalas e os estames; pétalas 5 , livres, desiguais, alongado-espatuladas, imbricadas na prefloração; estames 5, livres, todos férteis; filetes de comprimento diferente, achatados, anteras oblongo-iineares, subiguais basifixas, conectivo prolongado; disco urceolado, crenado-ondulado; ovário com ginóforo obcônico-alongado, muito longamente estipitado, 5locular, lóculos biovulados pequenos, unidos entre si pelo lado interno, ápice de cada lóculo com apêndice acuminado, longamente caudado; estilete filiforme, muito longo, estígma curtamente capitado. Fruto 2-3 cocas (por aborto das demais) desenvolvidas, livres até pró. ximo à base, rombóide-conchiformes, moderadamente comprimidas, dorso e ventralmente carinadas, com o lado externo munido de acúmen conspicuamente prolongado; semente $i$, oblonga, sub-reniforme, de ápice subacuminado, inflexo, dorsalmente carinada e ventralmente umbilicada.

Gênero monotípico, cuja espécie ocorre no Estado do Amazonas.

Espécie típica: $N$. speciosus Ducke. DISTRIBUIÇÃo - Região de Manaus na Amazônia Central, parte oriental do Estado do Amazonas.

Nycticalanthus difere, entre outros caracteres, dos outros gêneros por apresentar principalmente panículas de cimeiras longamente pedunculadas, flores bem compridas (até ca. de $10 \mathrm{~cm}$ de comprimento) e cocas com apêndice apical longamente caudado.

Nycticalanthus speciosus Ducke, Notizbl. Bot. Gart. Berlin 11: 341. 1932; Arch. Jard. Bot. Rio de Janeiro 6: 42-43. 1933. Foto 23.

Subarbusto a árvore pequena, até ca. de $6 \mathrm{~m}$ de altura. Folhas grandes, alternas, trifolioladas, até ca. de $57 \mathrm{~cm}$ de comprimento; pecíolos freqüentemente $20-30 \mathrm{~cm}$ de comprimento, às vezes mais longos, subcilíndricos sulcados por cima, mais ou menos tomentosos; foliolos curta e espessamente peciolulados, mais ou menos ovado-lanceolados ou obovados ou elíticos, base agudo-cuneada. ápice longamente caudado-acuminado, membranáceos, cobertos de pêlos esparsos por cima e densamente de pêlos moles por baixo, até ca. de $37 \mathrm{~cm}$ de comprimento e $14 \mathrm{~cm}$ de largura; nervuras mediana e secundárias proeminentes por baixo, vênulas frouxamente reticuladas. Inflorescência em panículas amplas, pedúnculos e ráquilas achatados principaimente no ápice, alvo-tomentosas por toda parte, em geral acima de $25 \mathrm{~cm}$ de comprimento Flores bem alvas, até ca. de $10 \mathrm{~cm}$ de compr: mento; cálice sub-herbáceo, alvo-seríceo por fora e glabro por dentro, $15-20 \mathrm{~mm}$ de compri mento por 8-9mm de largura, 5-dentado, dente agudos, apenas $2 \mathrm{~mm}$ de comprimento; pétalas levemente curvas, longamente cuneado-ate nuadas para a base e curtamente acuminadas no ápice, finamente seríceas por fora e por dentro, $80-90 \mathrm{~mm}$ de comprimento e ca. de $9 \mathrm{~mm}$ de largura; estames 5 , filetes pilósulos, glabros em direção à base; disco negro, brilhante. glabérrimo; ginóforo na antese ca. de $15 \mathrm{~mm}$ de comprimento; ovário $2 \mathrm{~mm}$ de altura, lóculos com apêndices de $7-8 \mathrm{~mm}$ de comprimento,

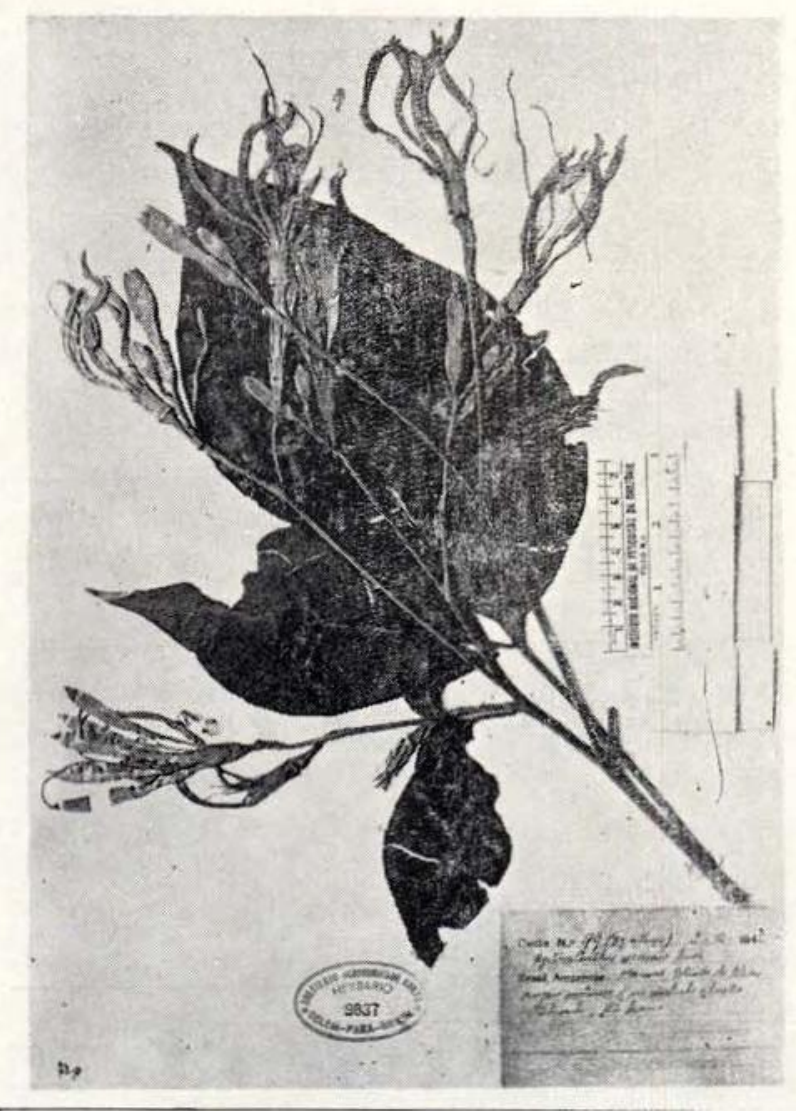

Foto 23. Nycticalanthus sp ciosus Ducke Ducke 99 (IAN, MG). 
densamente amarelo-seríceo como o ginóforo, estiletes mais longos que os estames e as pétalas, um pouco alvo-pilosos; estígma negro, glabro. Fruto cocas (ainda não amadurecidas) até $12 \mathrm{~mm}$ de comprimento, apêndice apical longirrostrado, $7-8 \mathrm{~mm}$ de comprimento, finamente alvo-tomentosas, endocarpo amarelo; ginóforo frutífero $16-18 \mathrm{~mm}$ de comprimento.

TIPO - Ducke $s / n$. Brasil. Amazonas, Ma. naus, estrada do Aleixo, fl (holótipo $R B$ 23550).

DISTRIBUIÇÃo - Provavelmente endêmica da região de Manaus parte do Amazonas oriental na Amazônia Central. Habita em mata pantanosa da margem de um igarapezinho (riachinho) de água preta da terra firme. Flores de outubro a janeiro do ano seguinte. BRASIL. Amazonas: Ducke $99 \mathrm{fl}$ (IAN, MG); Guedes $85 \mathrm{fl}$ (IAN); Mello INPA $2087 \mathrm{fl}$ (INPA, IAN 94702). Fig. 11.

Nycticalanthus speciosus é a única espécie até o momento descrita para o gênero Nycticalanthus.

Esta bela planta, segundo Ducke (1933) tem afinidades com o gênero Spiranthera, mas distingue-se dele pelas fíores zigomorfas, cálice longo, tubuloso e decíduo juntamente ccm. as pétalas, anteras basifixas, disco simplesmente crenado, ovário muito mais longamente estipitado e os lóculos mais longamente caudado-acuminados.

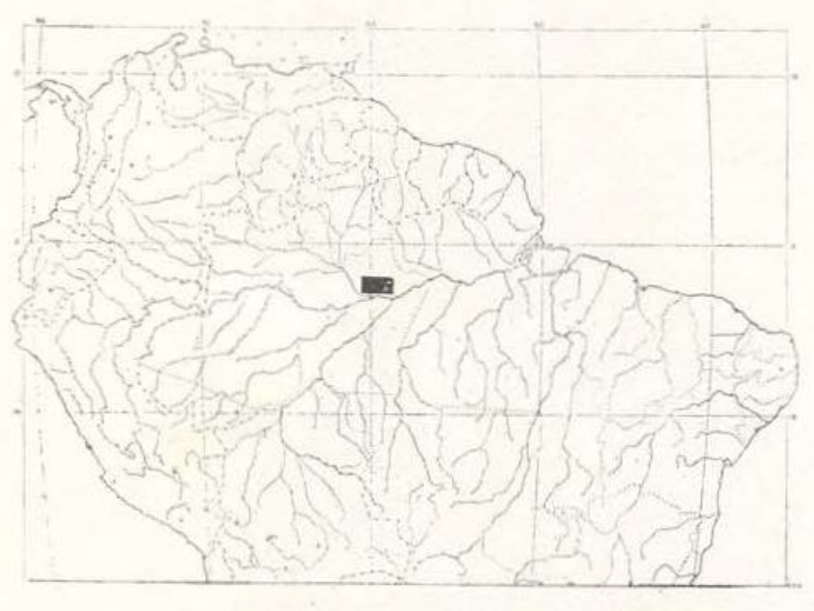

Fig. 11. Distribuição geográfica de $=$ Nycticalanthus speciosus.

(*) - Sinônimos citados por Engler (1874).
12. Raputia Aublet, Hist. Pl. Gui. Franç. 2: 670. 1775; Engler, in Mart. FI. Bras. 12 (2): 100. 1874; Albuquerque, An. Acad. brasil. Ci. 40 (4): 515. 1968.

Aruba Nees \& Mart., Nov. Act. Nat. Cur 11: 152. 1823. (*)

Pholidandra Neck., Elem.-1:348. 1790, (*)

Sciuris Schreb., Gen. 24. 1789. (*)

Arbustos a árvores pequenas. Folhas aiternas ou opostas, membranáceas ou subcoriáceas, 4-7-folioladas, glabérrimas em ambos os lados. Inflorescência longipedunculada, dicotomicamente ramificada, ramificações angulosas. Flores alvas, grandes, pediceladas, dispostas em cincinos racemiformes, hermafroditas, pentâmeras, zigomorfas; cálice cupu. lar, mais ou menos distintamente 5-dentado, às vezes bilabiado, membranáceo; pétalas 5 , oblongas ou oblongo-lanceoladas, seríceas por fora e vilosas por dentro principa!mente na metade, unidas em um tubo reto ou arqueaco, livres e muito imbricadas para o ápice, limbo bilabiado na antese; estames 5 , inseridos na base do disco, concrescidos na base com o tubo da corola, 2 férteis inferiores, filetes achatados, glabros, antera oblonga, conectivo freqüentemente biapendiculado na base, estaminódios subulados ou lineares, desiguais, alvo-vilosos na base ou pubérulos; disco urceolado, 5-dentado; ovário obovado, 5-lobado, 5-locular, lóculo com 2 óvulos superpostos, estilete filiforme, curvo, glabro, estígma capitado, sub-5-lobado. Fruto cápsula 5-locular; carpídios unidos lateralmente, oblongos, trígonos, obtusamente carinados no dorso, deiscentes até quase a metade; sementes 2 em cada carpídio, subglobosas.

1 espécie ocorre no Estado do Amazonas.

Espécie típica: $R$. aromatica Aublet.

DISTRIBUição - Da América Central, região das Antilhas (Cuba; Porto Rico), ao longo da América do Sul, até a Argentina.

Raputia distingue-se dos demais gêneros principalmente pela inflorescência dicotomicamente ramificada e cápsula com carpídios obtusamente carinados no dorso. 
Raputia subsigmoidea Ducke, Arch. Jard. Bot.

Rio de Janeiro 5: 143. 1930. Fotos 24 e 25.

Arbusto de ca. de $3 \mathrm{~m}$ de altura. Folhas digitadas, 5-folioladas (raro 4 ou 6-7), pecíolo achatado, marginado por cima, espesso na base, $20-30 \mathrm{~cm}$ de comprimento; folíolos ovados ou oblongo-lanceolados, subcoriáceos, base cuneado-atenuada, ápice moderadamente acuminado; folíolo apical com peciólulo de $2-4 \mathrm{~cm}$ de comprimento; lâmina até ca. de $50 \mathrm{~cm}$ de comprimento e $15 \mathrm{~cm}$ de largura. Inflorescência grande com o pedúnculo até próximo da primeira dicotomia de $15-40 \mathrm{~cm}$ de comprimento, achatado como os pecíolos, reto, glabro, dicotomicamente ramificada; ramificações alongadas e muito divergentes; cincinos floríferos pedunculados, flexuosos, com as flores dispostas ao longo do raque mais ou menos do mesmo lado e direção, partes jovens enro-

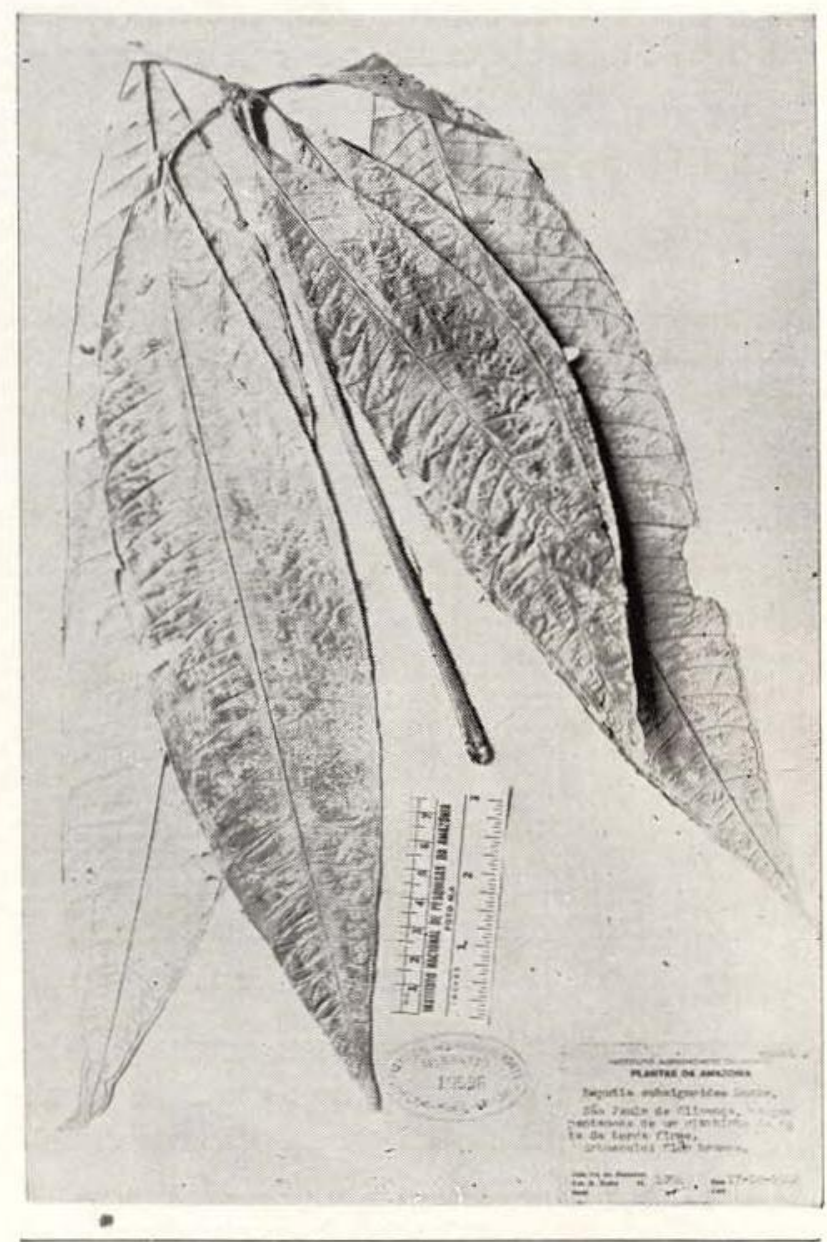

Foto 24. Raputia subsigmoidea Ducke. Ducke 1054 (IAN).

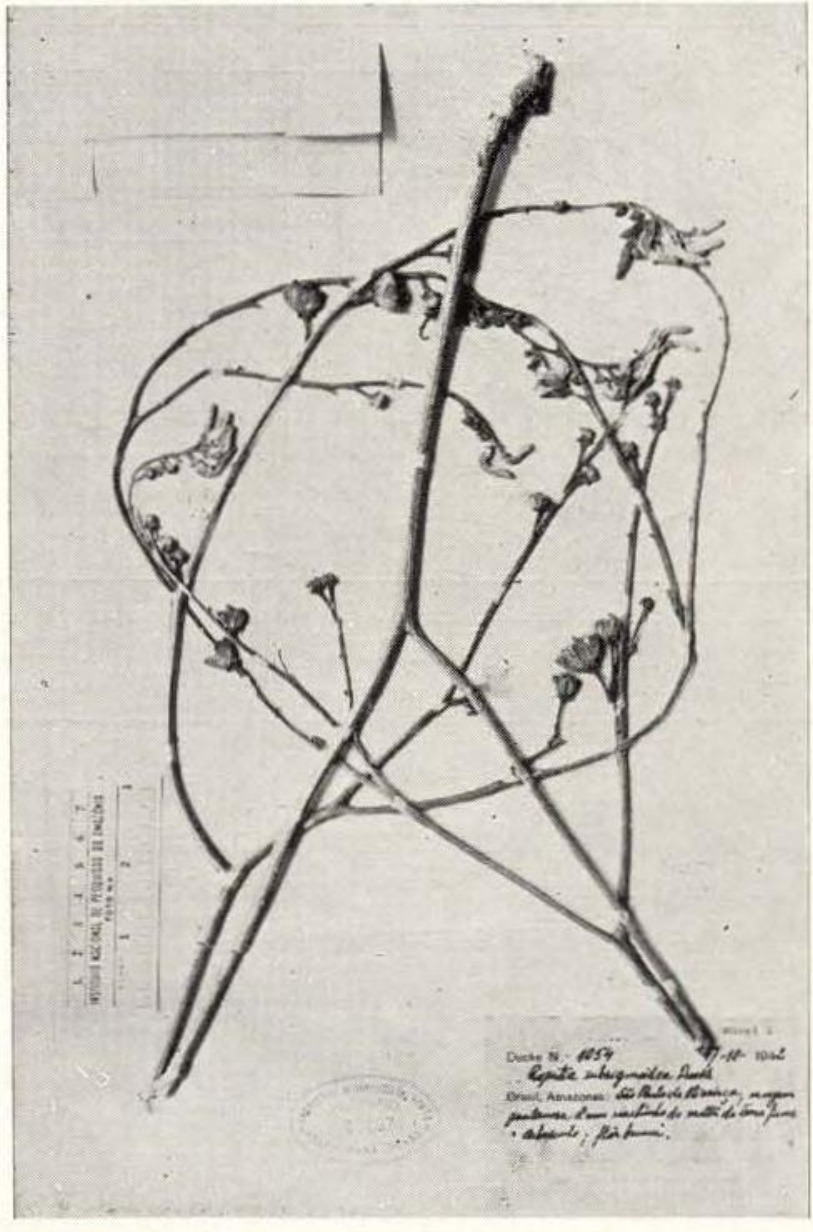

Foto 25. Raputia subsigmoidea Ducke. Ducke 1054 (IAN).

ladas para trás, ferrugíneo-tomentelas. Flores alvas, zigomorfas, ca. de $4 \mathrm{~cm}$ de comprimento; cálice na antese $3 \mathrm{~mm}$ de comprimento e $5-6 \mathrm{~mm}$ de largura, pardacento-tomentosos por fora $e$ glabros por dentro; corola finamente seríceo-esbranquiçada por fora e tomentelo-cinzenta por dentro, abertura longamente viloso-esbranquiçada, em botões florais adultos subsigmóide-biflexuosa (fortemente angulosa na base e levemente flexuosa no ápice, acima de $3 \mathrm{~cm}$ de comprimento na antese, lacínias alongado-obovadas, obtusas para o ápice, sendo 4 mais largas, anguloso-reflexas e 1 mais estreita, ereta; estames 5, 2 férteis, glabros; estaminódios 3, desiguais, subulados, de ápice acuminado e base viloso-esbranquiçada; disco urceolado, glabro; ovário incluso no disco, curtamente piloso, estilete glabro, estígma capitado. Fruto cápsula 5-locular, pilosa; carpídio oblongo, 


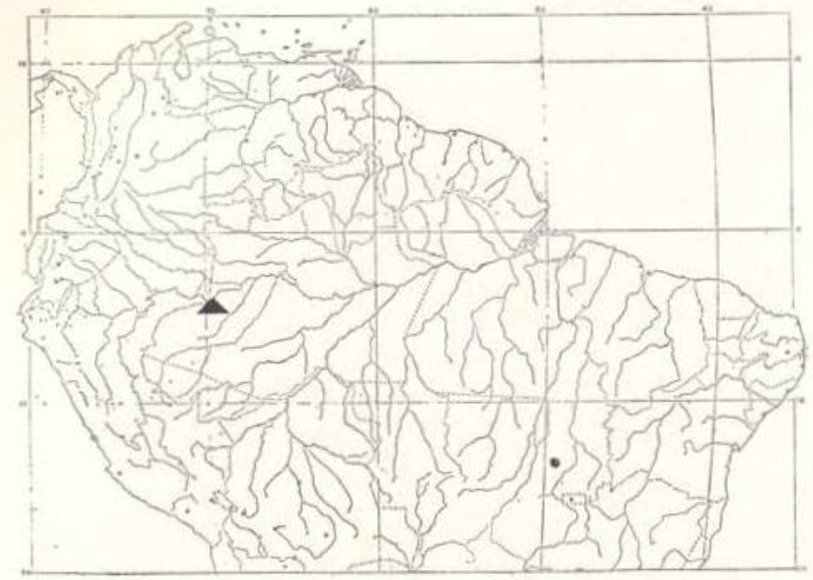

Fig. 12. Distribuição geográfica de $\boldsymbol{C}$ Raputia subsigmoidea.

trígono, lateralmente comprimido, munidc de apófise ascendente na parte apical do dorso, deiscentes no ápice; semente subglobosa, 2 por carpídio.

TIPo - Ducke $s / n$. Brasil. Amazonas, rio Solimões, São Paulo de Olivença, fl (holótipo; $R B$ 20503, n. v.).

DISTRIBUIÇÃo - Brasil, parte ocidental dc Estado do Amazonas, região do alto rio Solimões. Habita em margem pantanosa de pequenos igarapés da mata primária de terra firme. Colhida com flores em outubro-novembro e com frutos em outubro. BRASIL. Amazonas: Ducke $1054 \mathrm{fl}$ e fr (IAN). Fig. 12.

Raputia subsigmoidea, segundo Ducke (1930), é bem caracterizada pela forma da corola que a aproxima de $R$. sigmatanthus e as folhas se assemelham com as de $R$. paraensis e R. magnifica.

13. Ravenia Vellozo, FI. Flum. 1: 20. 1825; I, t. 49. 1827; Engler, in Mart. Fl. Bras. 12 (2): 125. 1874; Albuquerque, An. Acad. brasil. Ci. 40 (4): 522. 1968.

Lemonia Lindl., Bot. Reg. 13, t. 50. 1840. (*)

Árvore pequena, fétida, ramos inicialmente ruivos, depois pardos. Folhas opostas ou pseudo-alternas, "simples, pecioladas, herbáceo- membranáceas, distintamente translúcido-pontuadas. Inflorescência terminal ou axilar, ereta, de ramos floríferos racemosos ou em cimeiras de cincinos uni ou biflorais. Flores verdes, grandes, densamente glandulosas, hermafroditas, pentâmeras, zigomorfas; cálice dialissépado, com 5 sépalas fortemente imbricadas, desiguais, 2 externas maiores envolvendo 3 internas menores, orbiculares, elíticas ou subelíticas; corola gamopétala, de 5 pétalas, fortemente zigomorfa, tubo, amplo, densamente piloso por dentro, hipocrateriforme, lacínias imbricadas na prefloração, limbo bilabiado na antese; estames 5,2 férteis, adnatos ao tubo da corola abaixo do lábio superior, anteras grandes, ovado-oblongas, estaminódios 3 , adnatos na base do tubo da corola, com a parte livre longamente filiforme; filetes e estaminódios densamente lanosos na base; disco cupular, tênue, levemente 5-crenado; ovário 5-locular, glabro, incluso no disco, óvulos 2 por lóculo, superpostos, estilete único, estígma 5-lobado. Fruto 1-5 cocas bivalvas; semente 1 , subarredondado-triangular.

2 espécies do Estado do Amazonas.

Espécie típica: $R$. infelix Vellozo.

Distribuição - Do sudeste do Brasil até a América Central (Nicarágua, Cuba (AntiIhas) e Índias Ocidentais).

O gênero Ravenia separa-se dos demais gêneros principalmente pelo cálice fortemente imbricado, com 2 sépalas maiores envolvendo 3 menores.

\section{CHAVE PARA A DETERMINAÇÃO DAS ESPÉCIES DE RAVENIA}

1. Folhas opostas, normais; inflorescência birramificada; ramificações racemosas com flores alternadamente subdísticas.

\section{1. R. biramosa}

1. Folhas pseudo-alternas, uma normal persistente e outra reduzida ao tamanho de uma estípula, caduca; inflorescência em cimeiras de cincinos de 1 a 2 flores.

13. 2. R. pseudalterna

(") - Sinônimo mencionado por Engler (1874). 
13. 1. Ravenia biramosa Ducke, Arch. Inst. Biol. Veg. 2: 48. 1935. Foto 26.

Árvore pequena, fétida. Folhas opostas, simples, normais; lâmina obovada, elítica ou raro oblongo-lanceolada, base cuneado-aguda ou aguda, ápice acuminado, acúmen mais ou menos longo. Inflorescência birramificada com ramificações racemosas, alternadamente subdísticas; bractéolas lineares, terminando em glândula pequena no ápice. Flores verdes, mais numerosas, menores, sépalas elíticas ou orbiculares, 2 externas maiores que as $3 \mathrm{in}$ ternas, glabras por fora e seríceas por dentro; corola alcançando ca. de $22 \mathrm{~m}$ de comprimento na antese; anteras com conectivo internamente auriculado na base. Fruto 1-5 cocas.

TIPO - Ducke $s / n$. Brasil. Amazonas, Manaus, estrada do Aleixo, fl (holótipo: RB 24166, n. v.).

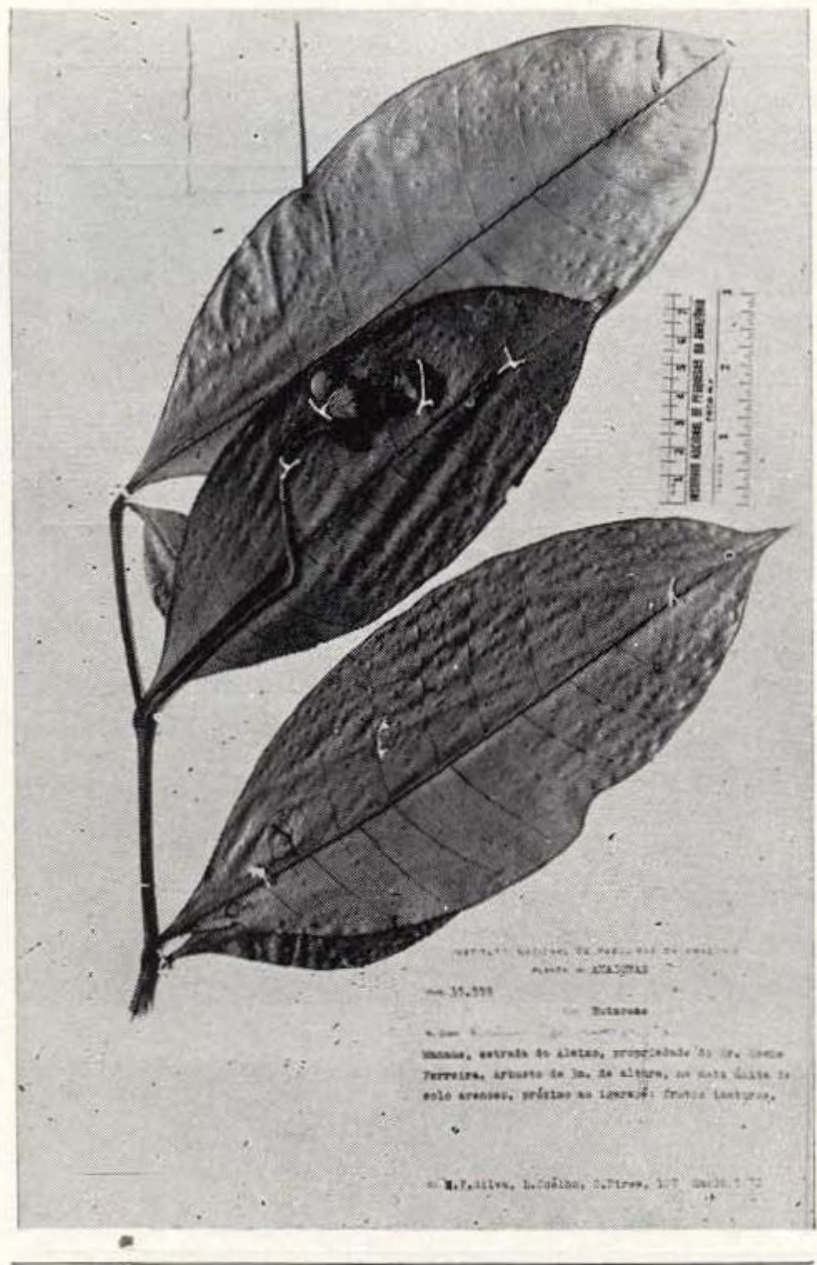

Foto 26. Ravenia biramosa Ducke. Silva et al, 107 (INPA).
DISTRIBUIÇÃo - Amazônia Central, parte oriental do Estado do Amazonas, região de Manaus. Habita em mata primária de terra firme argilosa, úmida. Colhida com flores em fevereiro e com frutos em maio. BRASIL. Amazonas: Silva et al. $107 \mathrm{fr}$ (INPA). Fig. 13.

Ravenia biramosa distingue-se de $R$. pseudalterna principalmente pelas folhas opostas normais e inflorescência birramificada.

13. 2. Ravenia pseudalterna Ducke, Arch. Inst. Biol. Veg. 2: 49. 1935. Foto 27.

Árvore pequena, fétida. Folhas pseudoalternas, simples, (parecem alternas mas que na realidade são opostas, com uma folha normal, persistente e a outra reduzida a uma estípula muito caduca); lâmina das folhas normalmente desenvolvidas levemente oblongo-obo-

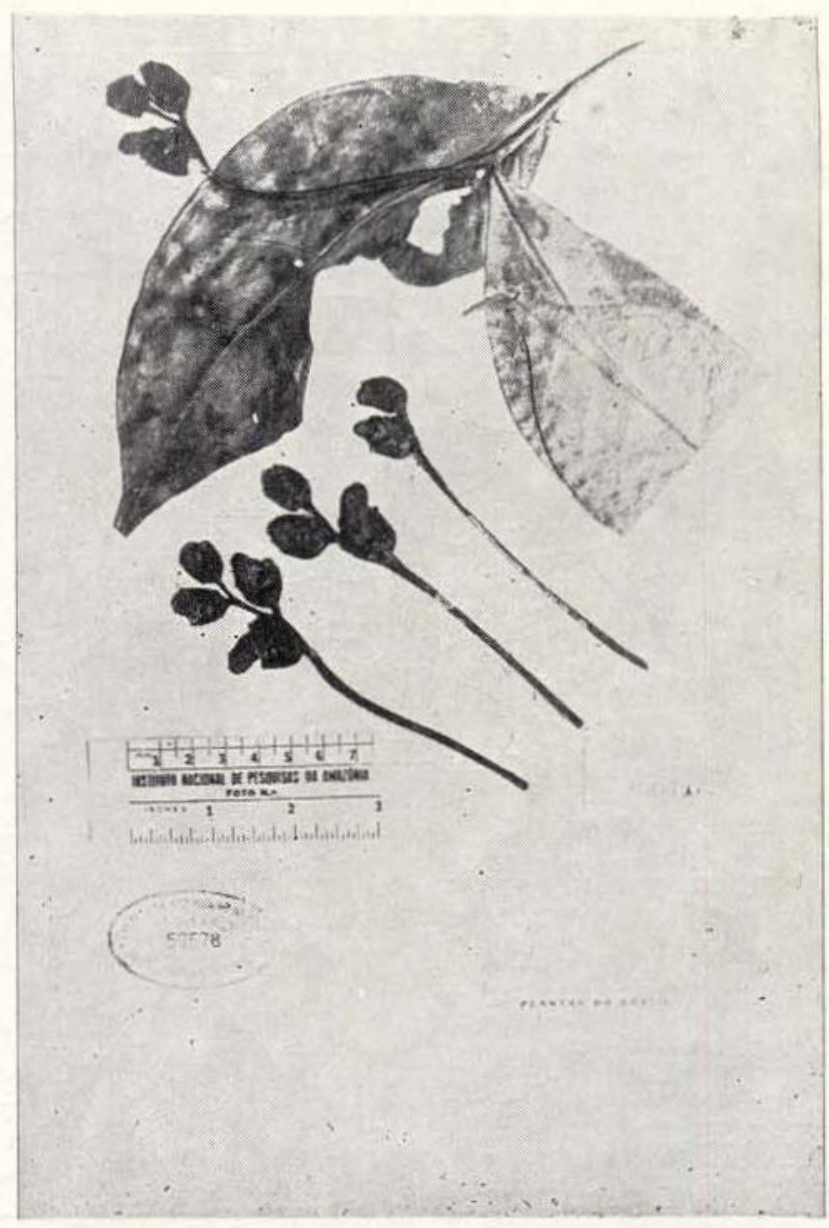

Foto 27. Ravenia pseudalterna Ducke. Ducke IAN 50578 (isotipo). 
vada, base aguda e curtamente enrolada, ápice brusca e lorıgamente acuminado, herbáceo-membranácea, distintamente translúcidopontuada; folhas rudimentares facilmente caducas, estreitas, agudamente lanceoladas, adpresso-pilosas no ápice. Inflorescência terminal, ereta, em cimeiras de cincinos uni ou biflorais. Flores verdes, poucas, freqüentemente 3-5, densamente glandulosas, maiores; sépalas mais ou menos elíticas, 2 externas maiores que as 3 internas, a maior delas muito convexa; corola alcançando ca. de $40 \mathrm{~mm}$ de comprimento; anteras com conectivo provido internamente de apêndice subcalcariforme na base e sub-bilobado-dilatada no ápice. Fruto desconhecido.

TIPOS - Ducke $s / n$. Brasil. Amazonas, rio
Negro, São Gabriel da Cachoeira, serra Cabari, fl (holótipo: RB 24167, n. v.; isótipo IAN).

DISTRIBUIÇÃo - Região do alto rio Negro, parte norte do Estado do Amazonas, Brasil. Habita em campina arenosa ou em mata primária de terra firme muito úmida de solo humoso. Flores em janeiro e fevereiro. BRASIL. Amazonas: Rodrigues $926 \mathrm{fl}$ (INPA, MG, IAN); INPA $7329 \mathrm{fl}$ (INPA); Pires $403 \mathrm{fr}$ (IAN); Ribeiro $249 \mathrm{fl}$ (IAN). Fig. 13.

NOMES vULGARES - Brasil. Taiaçumirá, Taiaçucaá (Amazonas, alto rio Negro).

Ravenia pseudalterna separa-se de R. biramosa por apresentar principalmente folhas pseudo-alternas e inflorescência em cimeira de cincinos.

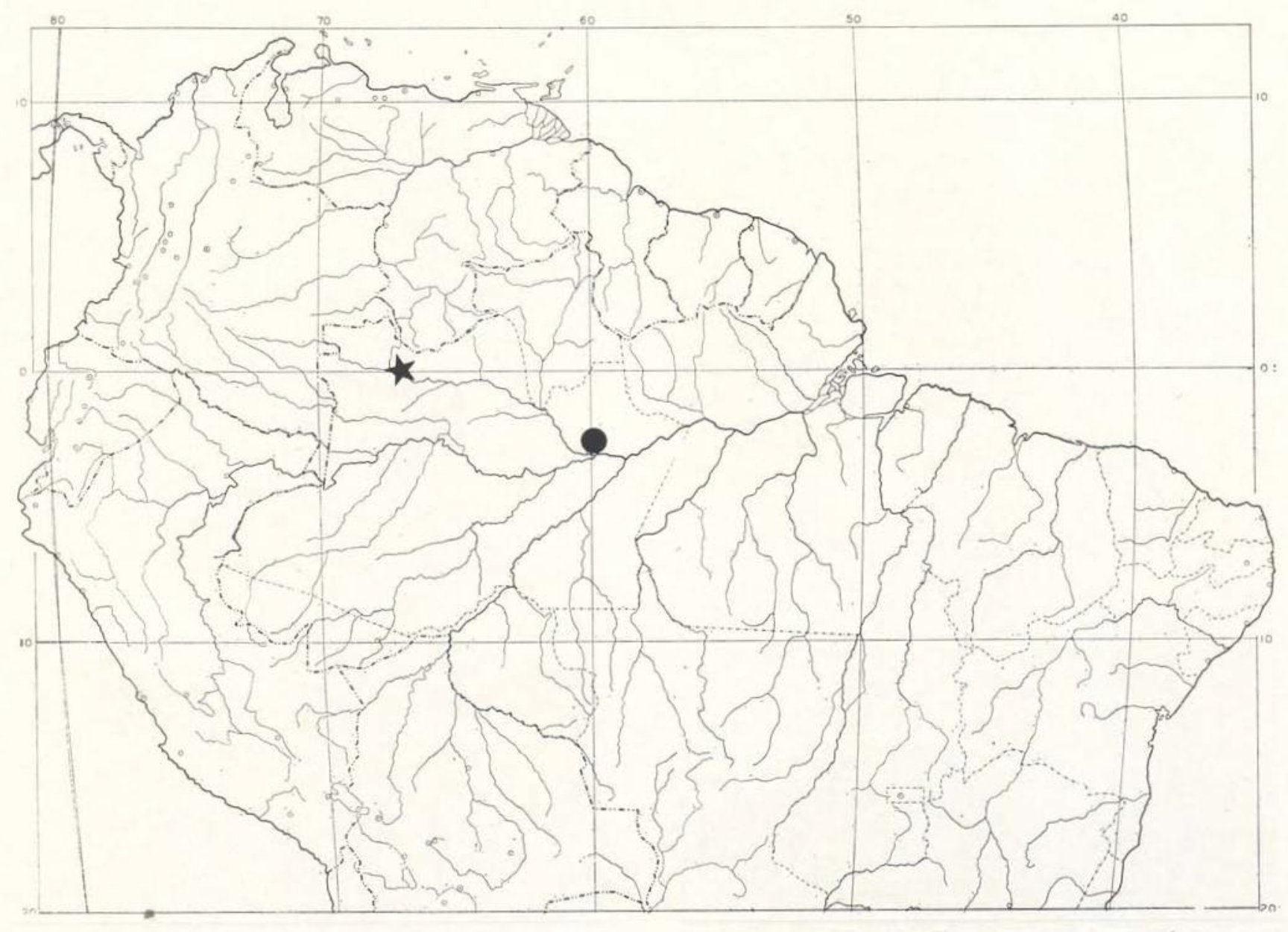

Fig. 13. Distribuição geográfica de Ravenia biramosa e $\nmid$ R. pseudalterna. 
14. Spathelia Linnaeus, Sp. PI. ed. 2, 1: 386. 1763 (n. cons.) (em. e ampl.); Candolle, Prodromus 2: 84. 1825; Cowan, Mem. N. Y. Bot. Gard. 10 (2): 59. 1960 e 14 (3): 2.1967.

Spathe R. Brown, Hist. Jam. 187. 1756 (n. rej.). (*)

Sohnreyia Krause, Notizbl. Bot. Gart. Mus. Berlin 6 : 147-149. 1914. (")

Diomma Engler ex Harms., Natur. Pflanzenf. ed. 2, 19a. : 460. 1931. (*)

Árvore até ca. de $20 \mathrm{~m}$ de altura, monocárpica, com aspecto de palmeira. Folhas grandes, compostas, alternas, aglomeradas no ápice do caule monopodial, 10-100 pares de folíolos, até ca. de $2,70 \mathrm{~m}$ de comprimento; folíolos de alternos a opostos, ovados, oblongos, oblongo-ovados, oblongo-elíticos ou oblongolanceolados, margem inteira a crenada, glândulas translúcidas freqüentemente distribuidas através da lâmina foliolar ou restritas às margens. inflorescência em panículas grandes, terminais, até ca. de $3 \mathrm{~m}$ de comprimento. Flo res alvas, polígamas, pentâmeras, actinomorfas; sépalas 5 , livres ou levemente unidas na base, valvares ou imbricadas na prefloração; pétalas 5 , livres, imbricadas na prefloração; estames 5 , livres, todos férteis, filetes salientemente alados, alas densamente vilosas, curtamente livres no ápice, bidentadas; disco ginoforóide; ovário subséssil ou estipitado, 2-3-locular, lateralmente comprimido, lóculos uniovulados, óvulos pêndulos, estígma séssil ou subséssil, 2-3-lobado. Fruto sâmara 2-3-alada, alas mais curtas ou mais longas do que a porção revestidora da semente; semente com ou sem endosperma.

1 espécie ocorre no Estado do Amazonas.

Espécie típica: S. simplex Linnaeus.

DISTRIBUIÇÃo - Das Bahamas (Índias Ocidentais) através de Cuba e Jamaica (regiōes das Antilhas e do Caribe) até o sul da Amazônia brasileira (Rondônia e Mato Grosso).

O gênero Spathelia distingue-se dos demais gêneros por apresentar principalmente árvores com aspecto de palmeira, monocárpicas, pelas inflorescências muito grandes, flores pôlígamas e frutos alados.
Spathelia excelsa (Krause) Cowan \& Brizicky, Mem. N. Y. Bot. Gard. 10 (2): 64. 1960; Rodrigues, Publ. INPA; Bot. 14: 3-7. 1962. Fotos 28,29 e 30 .

Sohnreyia excelsa Krause, Notizbl. Bot. Gart. Mus. Berlin 6 : 148, 1914. Tipo. Ule 8899. Brasil. Amazonas, Manaus, Cachoeira Grande do Tarumã (holótipo B, perdido).

Árvore 10-20m de altura, monocárpica, com aspecto de paimeira. Folhas grandes, 30-54 pares de folíolos, até ca. de 2,64m de comprimento, pecíolo até ca. de $14 \mathrm{~cm}$ de comprimento, profundamente canaliculado para a base, raque até ca. de 2,50m de coprimento; folíolos

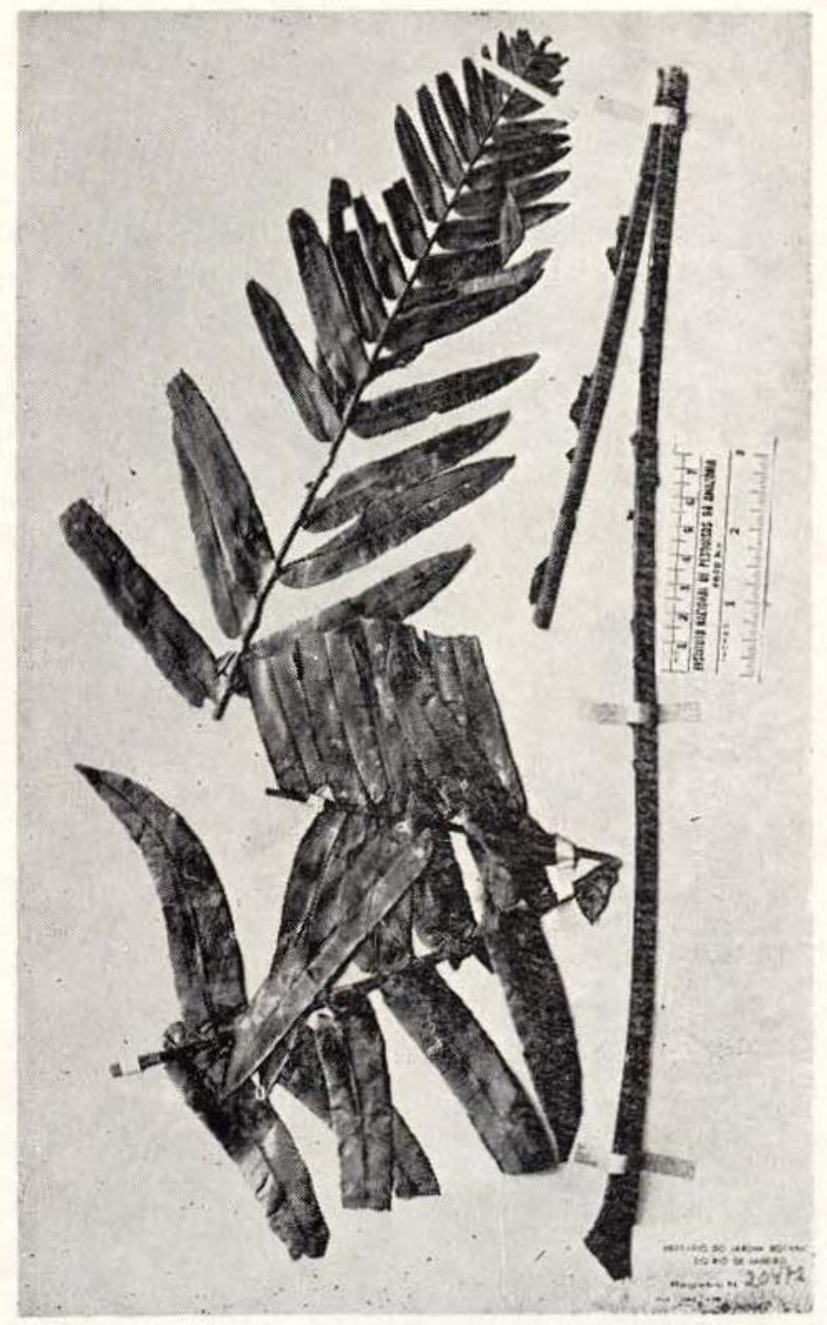

Foto 28. Spathelia excelsa (Krause) Cowan \& Brizicky. Ducke RB 20472.

(*) - Sinônimos citados por Cowan \& Brizicky (1960) e Cowan (1967). 
subpostos ou alternos com glândulas transiúcidas dispersas; lâminas dos folíolos medianos estreitamente oblongas ou oblongo-lanceoladas, levemente arqueadas, $23-30 \mathrm{~cm}$ de comprimento e $3,5-5-5 \mathrm{~cm}$ de largura, base muito desi. gual com ambos os lados arredondados ou o lado superior subobtuso, ápice acuminado, acúmen truncado; nervura mediana e 20-30 pares de nervuras secundárias planas por cima e salientes por baixo. Inflorescência em panícula terminal, densamente pubescente, até ca. de $3 \mathrm{~m}$ de comprimento; brácteas primárias foliáceas, ca. de $20 \mathrm{~mm}$ de comprimento po: $5 \mathrm{~mm}$ de largura, estreitamente elíticas; brácteas secundárias ca. de $1 \mathrm{~mm}$ de comprimento, estreitamente triangulares; bractéolas muito pequenas. Flores alvas; sépalas largamente ovadas a arrediondadas, $1-2 \mathrm{~mm}$ de comprimen-

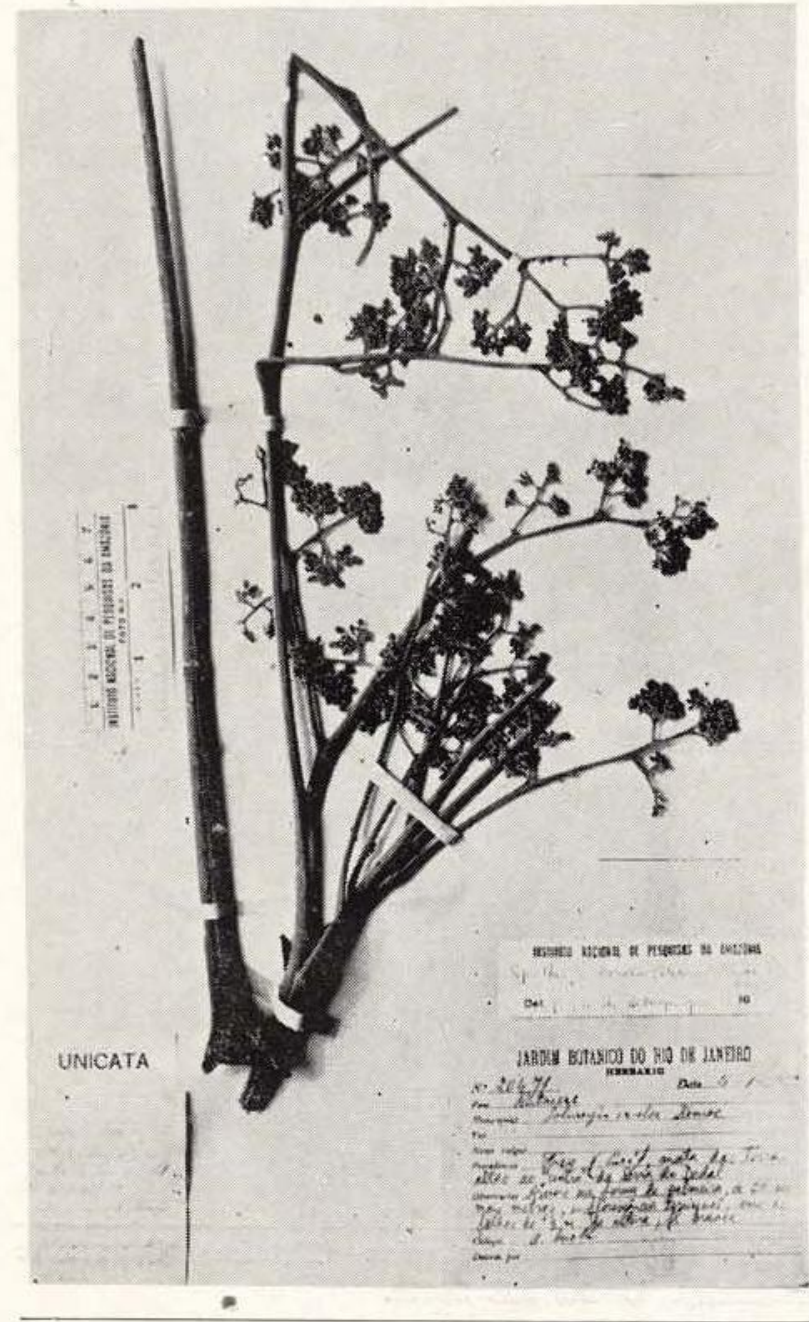

Foto 29. Spathelia excelsa (Krause) Cowan \& Brizicky. Ducke RB 20471.

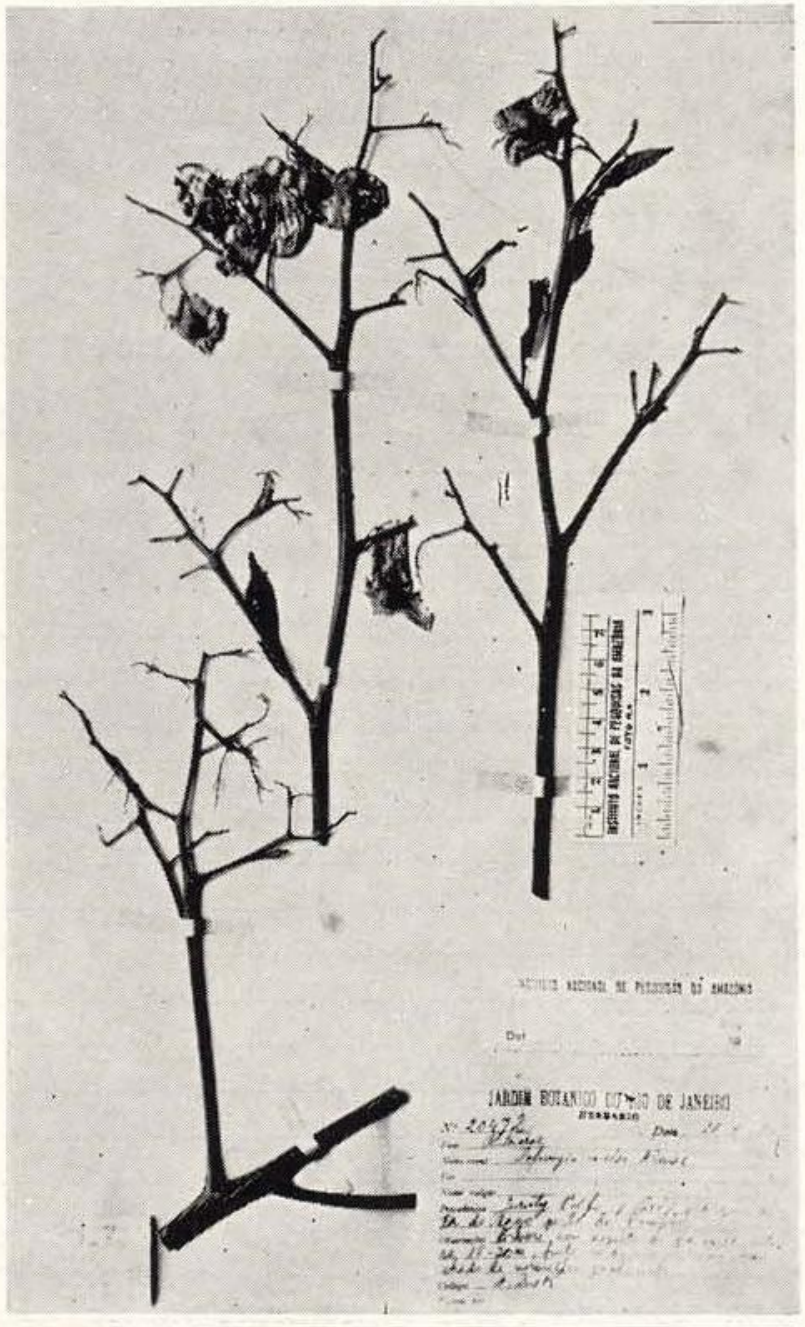

Foto 30. Spathelia excelsa (Krause) Cowan \& Brizicky. Ducke RB 20472.

to e largura; pétalas elíticas, obtusas, glabras, $4-6 \mathrm{~mm}$ de comprimento e $2-3 \mathrm{~mm}$ de largura; filetes nas flores masculinas $2-4 \mathrm{~mm}$ de com. primento, de base alada, alas bidentadas e densamente vilosas, com a porção apical iigeiramente livre; ginóforo $1-2 \mathrm{~mm}$ de comprimento por 4,5-6mm de diâmetro, glabro; ovário ovóide, glabro, estígma séssil. Fruto verde-avermelhado com pintas vermelho-pardas, sâmara 2-alada, alas largas, cordada na base, glabra, $2,5-3,5 \mathrm{~cm}$ de comprimento e $4,5-6 \mathrm{~cm}$ de largura, a porção que recobre a semente ca. de $8 \mathrm{~mm}$ de comprimento $5 \mathrm{~mm}$ de largura.

TIPOS - Ule 8899. Brasil. Amazonas, Manaus, Cachoeira Grande do Tarumã, fl e fr (holótipo: B, perdido; foto isótipo: NY). 
DISTRIBUIÇÃo - Parte norte do rio Amazonas, na Amazônia Central, de Manaus até o baixo Trombetas e parte sul, de Maués e Juruti Velho até o Território de Rondônia e norte de Mato Grosso. Habita em mata näo muito densa, de terra firme, continental ou na margem de igarapé ou lago. Colhida com flores de dezembro a março do ano seguinte e com frutos em maio. BRASIL. Amazonas: Rodrigues $2080 \mathrm{fl}$ (INPA). Pará: Ducke RB $8567 \mathrm{fl}$ (RB; $M G$ 15702); $R B \quad 13613 \mathrm{fl}$ (RB); $R B 20471 \mathrm{fl}$ (RB); $R B 20472 \mathrm{fr}$ (RB). Fig. 14 .

NOME VULGAR - Brasil: Surucucumirá (Amazonas, rio Cuieiras).

Usos - Segundo Rodrigues (1962), Spathelia excelsa tem alto valor ornamental. Record \& Hess apud, Rodrigues (1962) salientam que a madeira presta-se para diversos fins. contudo não é encontrada em quantidade suficiente para ser considerada de importância econômica.

Spathelia excelsa está incluída no subgênero Sohnreyia, de acordo com estudos taxonômicos feitos por Cowan \& Brizicky (1960).

Milanez (1943) efetuou o estudo anatômico da madeira de $S$. excelsa.

15. Ticorea Aublet, Hist. PI. Gui Franç. 2: 689, t. 277. 1775; Engler, in Mart. FI. Bras. 12 (2) : 91-92. 1874; Lemée, FI. Gui. Franç. 2: 182. 1952.

Ozophyllum Schreb. Gen. 2: 452. 1781. (*)

Arbustos a árvores até ca. de $5 \mathrm{~m}$ de altura. Folhas trifolioladas, raro 4-folioladas, alternas, membranáceas; folíolos oblongo-elíticos, de-

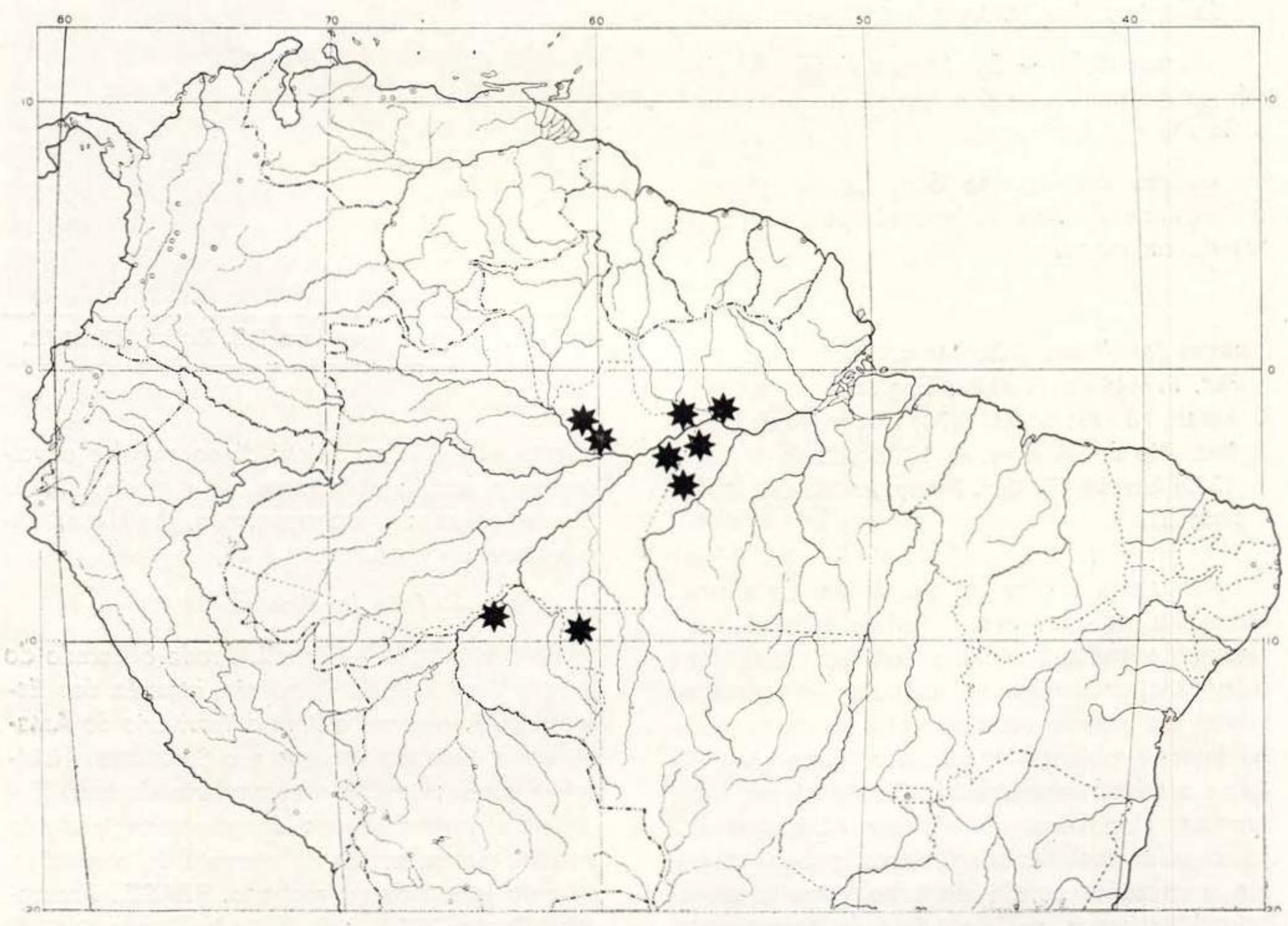

Fig. 11. Distribuição geográfica de * Spathelia excelsa

(") - Sinônimo mencionado por Engler (1874). 
siguais, o terminal maior que os laterais, atenuado em ambos os extremos, ápice acuminado, os laterais de base oblíqua e ápice atenuado-acuminado. Inflorescências longipedunculadas, densamente corimboso-paniculadas. Flores alvas, grandes, numerosas, hermafroditas, pentâmeras, zigomorfas; cálice pequeno, cupular, 5-dentado; corola gamopétala (5 pétalas) de tubo reto, cilíndrico, hipocrateriforme, lacínias iguais; estames 5 , inseridos na base do disco, todos férteis, filetes adnatos ao tubo da corola em quase todo o comprimento, anteras oblongas; disco cupular; ovário obovado, 5-locular, incluso no disco, óvulos 2 por lóculo, superpostos, estilete filiforme, estígma espesso, subclavado. Fruto cocas oblongas; semente 1, oblonga, comprimida, lisa.

\section{1 espécie do Estado do Amazonas.}

Espécie típica: $T$. foetida Aublet.

DISTRIBUIÇÃo - Do Acre e Rondônia, através do Amazonas, Pará e Amapá, no Brasıl, até a Guiana e o Suriname.

Ticorea distingue-se dos demais gêneros principalmente pela inflorescência em cimeiras de corimbos.

Ticorea longiflora DC., Mem. Mus. Hist. Nat. Par. 9: 146, t. 9. 1822; Engler, in Mart. FI. Brasil. 12 (2): 92-93. 1874; Ducke, Arch. Jard. Bot. Rio de Janeiro, 4: 101. 1921 e 5: 143. 1930; Lemée, FI. Gui. Franç. 2: 182-183. 1952. Foto 31 .

Arbusto a árvore até ca. de $5 \mathrm{~m}$ de altura, com odor desagradável. Folhas trifolioladas, finamente membranáceas; folíolos desiguais, o terminal maior que os laterais, elítico, atenuado em ambos extremos, ápice acuminado, os laterais oblongo-lanceolados, base oblíqua, ápice atenuado-acuminado. Flores alvas, raro cremes, alongadas, aromáticas; cálice pequeno, cupular, lacínios triangulares, pubescentes, até a metade; corola de tubo estreitamente infundibuliforme, ca. de $4-5 \mathrm{~cm}$ de comprimento, lacínias desiguais, oblongo-obtusas; estames adnatos ao tubo da corola, anteras amarelas conectivo apendiculado na base, obtusa-

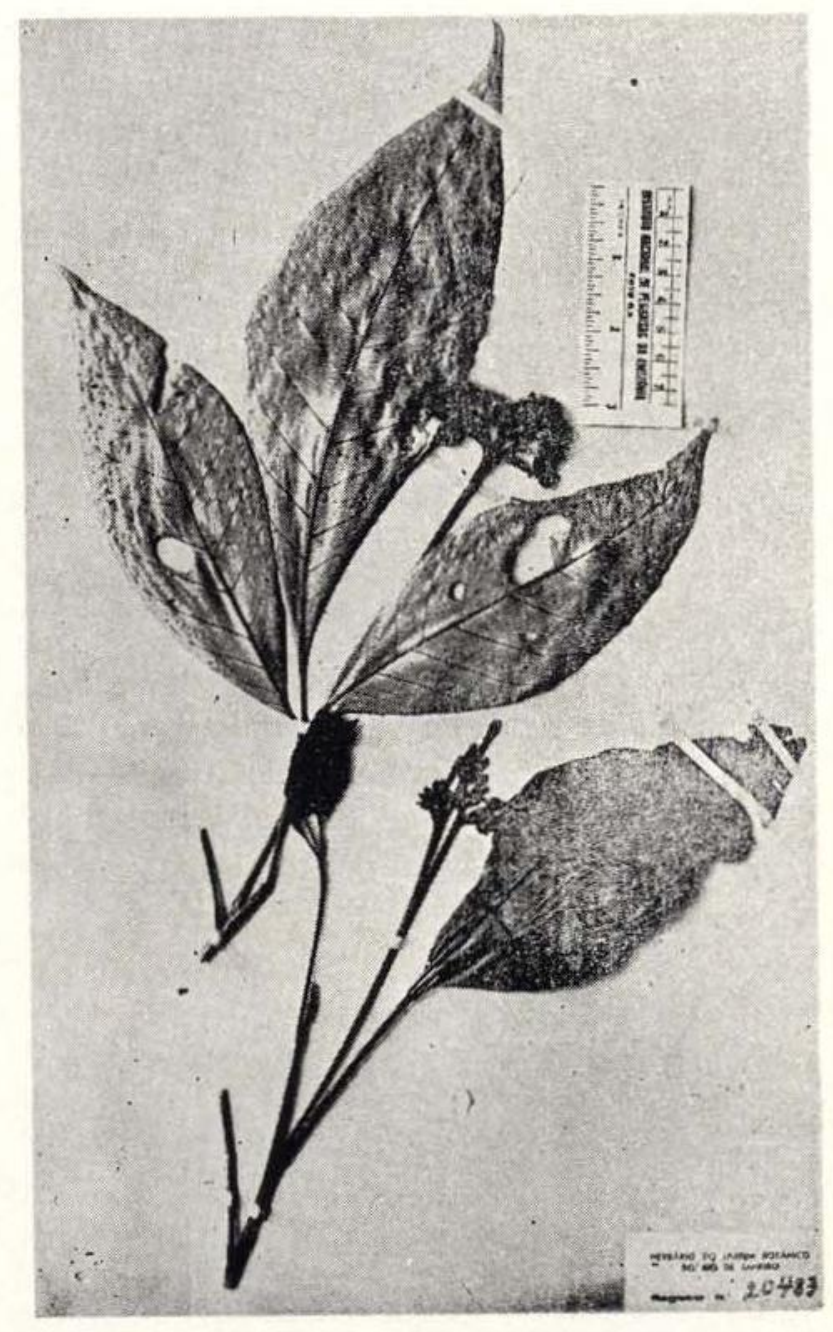

Foto 31. Ticorea longiflora DC. Ducke RB 20483.

mente bilobado no ápice; disco cupular envolvendo o ovário até acima da metade. Fruto cocas oblongas, monospermas, bivalvas, negras quando maduras.

$$
\text { TIPOS - (não localizados). }
$$

DISTRIBUIÇÃo - Brasil, desde o Estado do Acre e Território de Rondônia, através dos Estados do Amazonas e Pará e Território do Amapá, até a Guiana Francesa e o Suriname. Habita em mata primária e secundária de terra firme pantanosa ao longo de pequenos igarapés ou não, ou em matas de encosta de elevaçōes de solo laterítico ou rochoso. BRASIL. Amazonas: Boyan $297 \mathrm{fl}$ e fr (INPA); Ducke $1053 \mathrm{fl}$ (IAN); RB $20483 \mathrm{fl} \mathrm{e} \mathrm{fr} \mathrm{(RB);} \mathrm{Pires} \mathrm{\&} \mathrm{Black}$ $963 \mathrm{fl}$ (IAN); Prance et al. $2444 \mathrm{fl}$ (INPA); 3304 fl (INPA); 16464 fl (INPA). Pará: Ducke RB 
$17740 \mathrm{fl}$ (RB). Território do Amapá: Pires \& Westra $48850 \mathrm{fr}$ (IAN). Território de Rondônia: Prance et al. $5223 \mathrm{fl}$ (INPA); 6651 il (INPA): $8978 \mathrm{fr}$ (INPA). Fig. 15.

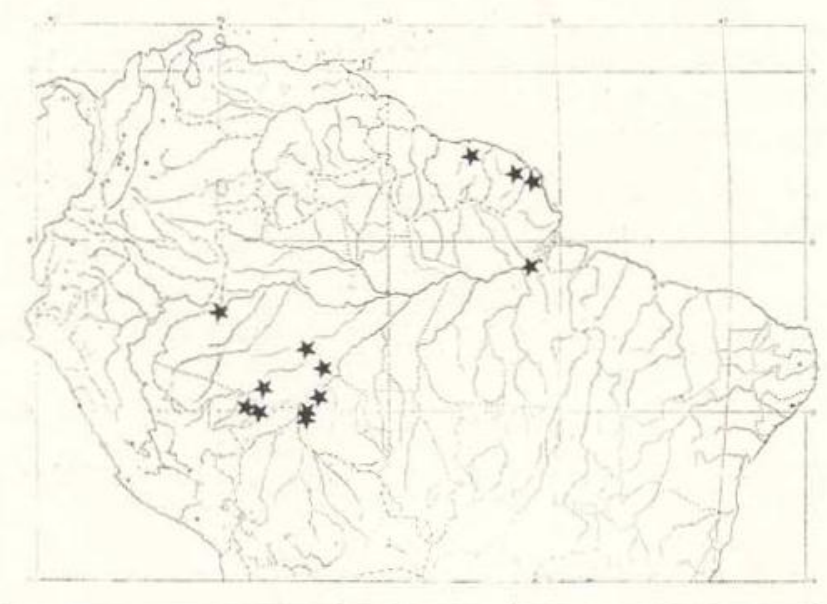

Fig. 15. Distribuiçãc geográfica de $¥$ Ticorea longiflora.

16. Zanthoxylum Linnaeus, Hort. Cliff. 487. 1737; Engler, in Mart. FI. Bras. 12 (2): 151 - 152. 1874; Waterman, Taxon $24(2 / 3)$ : $361-366.1975$.

Blackburnia Forst., Char. Gen. t. 6. 1776. (") Curtisia Schreb., Gen. 199. 1789. (")

Fagara Linnaeus, Syst. Nat. ed. 10, 2: 897. $1759\left(^{*}\right)$; Lemée, Fl. Gui. Franc. 2:179. 1952; Cowan, Sellowia 12:79-97. 1969; Albuquerque, An. Acad. Brasil. Ci. 40(4) : 501. 1968; Bol. INPA, sér. Pesq. Flor. $13: 1-2.1970$.

Ochroxylum Schreb., Gen. 826. 1791. (*)

Pohlana Leand. Sacram., Denkschr. Akad Muench. 229, 1819. (*)

Tobinia Desv., in Ham. Prod. Pl. Ind. Occ. 56. 1825. (*)

Arbusto a árvore até $30 \mathrm{~m}$ de altura e $45 \mathrm{~cm}$ de diâmetro de fuste (DAP), freqüentemente munidos de acúleos. Folhas compostas, alternas, imparipinadas, raro paripinadas, glabras ou pilosas, 2 a 17 pares ou mais de folíolos. até ca. de $76,5 \mathrm{~cm}$ de comprimento; folíolos freqüentemente opostos, mais ou menos oblongos, geralmente desiguais na base, acuminados a retusos no ápice, margem inteira, levemente crenulada, crenulada, crenada ou crenado-serrada. Inflorescência em panículas maiores ( $\hat{o}$ ) e menores ( $q$ ) de cimeiras, axilares ou terminais. Flores alvas em gerai, às vezes esverdeadas ou amareladas, pequenas, dióicas, tetrâmeras, pentâmeras ou hexameras, actinomorfas; cálice com 4-6 sépalas livres ou levemente concrescidas na base, imbricadas na prefloração; pétalas 4-6, livres, oblongas, mais ou menos côncavas, imbricadas ou valvares na prefloração; flores masculinas: estames 4-6, livres, anteras ovais ou oblongo-ovadas, bilobadas na base, ovário rudimentar; flores femininas: estames muito reduzidos, estéreis ou ausentes, disco ginoforóide, ovário 1-5-locular, disposto sobre o disco, lóculos livres ou raro unidos no ápice, óvulos 2 por lóculo, colaterais, estiletes livres ou ligeiramente soldados, estígmas capitados, 4-5-lobados. Fruto 1-5 cocas, de avermelhadas a marrom quando maduras, secas ou drupáceas, mais ou menos globosas ou largamente obovadas, deiscentes em duas valvas, monospermas; semente subglobosa, negra, brilhante, lisa, freqüentemente pendente fora do lóculo na maturidade.

7 espécies ocorrem no Estado do Amazonas.

Espécie típica: Z. fraxineum Willd.

DISTRIBUIÇão - Contínua pelas regiões tropicais quentes e úmidas do mundo.

Zanthoxylum separa-se dos demais gêneros, principalmente, por apresentar acúleos no caule e nos ramos, flores dióicas e semente pendente fora do lóculo na maturidade.

Waterman (1975) apoiou Brizicky (1962) e Hartley (1966) em recolocar Fagara L. como sinônimo do gênero Zanthoxylum L. pelas características morfológicas e químicas afins que as espécies deste complexo apresentam, não havendo necessidade de separá-los. Fez 54 combinações novas para o gênero Zanthoxylum incluindo 9 espécies do Estado do Amazonas e deu nome novo a 1 espécie, denominando-a Zanthoxylum huberi Waterman, que antes se denominava Fagara caudata Huber.

$\left({ }^{*}\right)$ - Sinônimos mencionados por Engler (1874). 


\section{CHAVE PARA A DETERMINAÇÃo DAS ESPÉCIES DE ZANTHOXYLUM}

1. Lâmina foliolar de margem inteira.

2. Folíolos ovado-lanceolados ou oblanceolados com o ápice caudado; ovário unilocular; estilete lateral; fruto piriforme.

\section{Z. huberi (16. 4.)}

2. Folíolos não ovado-lanceolados nem oblanceolados, mas com o ápice acuminado; ovário com mais de um lóculo; estilete terminal; fruto nāo piriforme.

3. Lâmina foliolar freqüentemente subobovada ou raro oblongo-elítica, acúmen de ápice agudo, às vezes retuso; inflorescência com ramificações angulosas.

Z. grazieliae (16. 3.)

3. Lâmina foliolar oblongo-elítica, raro elítića, acúmen de ápice sempre agudo; inflorescência com ramificações subcilíndricas.

\section{Z. prancei (16. 6.)}

1. Lâmina foliolar de margem levemente crenulada, crenulada ou mais ou menos profundamente crenada ou crenado-serrada.

4. Folíolos glabros; inflorescência e infrutescência compactas.

$$
\text { Z. compactum (16. 1.) }
$$

4. Folíolos pilosos; inflorescência e infrute cência laxas.

5. Pelos simples, longos; margem dos folíolos levemente crenulada ou crenulada.

6. Árvore grande, muito esgalhada, até $30 \mathrm{~m}$ de altura; pecíolos, peciólulos e face inferior da lâmina foliolar velutinos; infrutescência com ramificações subquadrangulares.

$$
\text { Z. machadoi (16. 5.) }
$$

6. Arvoreta não ramificada até $8 \mathrm{~m}$ de altura; pecíolo, peciólulo e face inferior da lâmina foliolar pilosos, mas não velutinos; infrutescência com ramificaçōes angulosas.

$$
\text { Z. djalma-batistae (16. 2.) }
$$

5. Pelos estrelados; margem dos folíolos crenada ou crenado-serrada.

$$
\text { Z. rhoifolium (16. 7.) }
$$

16. 1. Zanthoxylum compactum (Huber ex Albuquerque) Waterm. Taxon 24363. 1975. Foto 32.

Fagara compacta Huber ex Albuq., Publ. INPA 27: 12, tab. 11. 1968. Tipo. Ducke MG 10542 Brasil. Pará, Faro, paraná do Adauacá (holótipo).

Árvore pequena a mediana até ca. de $18 \mathrm{~m}$ de altura e $35 \mathrm{~cm}$ de diâmetro de fuste (DAP); ramos cobertos de manchas esbranquiçadas. Folhas grabriúsculas, paripinadas, raro imparipinadas, com 2-7 pares de folíolos, pecíolos cobertos de manchas esbranquiçadas, pubérulos; folíolos oblongo-elíticos, coriáceos, glabros, nítidos em ambas as faces, base aguda, ápice acuminado, às vezes retuso, margem indistintamente ou levemente crenulada, glandulífera; nervura mediana às vezes aculeada. Inflorescência em panículas termi- nais com ramificações eretas, densifloras, muito angulosas, munidas de bractéolas de base larga. Flores masculinas alvas, curtamente pediceladas; cálice cupular, 5-laciniado, lacínios livres, ovado-triangulares, agudos; péta. las 5 , oblongo-elíticas, glabras, vênula central promínula na face interna, não ramificada; estames 5 , filetes achatados na base, atenuados. anteras ovado-oblongas, ruivas; ovário rudimentar com 5 lóculos separados, estigmados, disposto sobre um ginóforo glabro; flores femininas desconhecidas. Fruto $4-5$ cocas vermelho-escuras quando maduras, subglobosas, carinadas, concrescidas na base, deiscentes em duas valvas arqueadamente sulcadas, rugoso-glandulosas, dispostas em ramos frutíferos paniculados, compactos; semente 1, rugosa.

TIPOS - Ducke MG 10542. Brasil. Pará, Faro, paraná do Adauacá, fr holótipo: MG); 


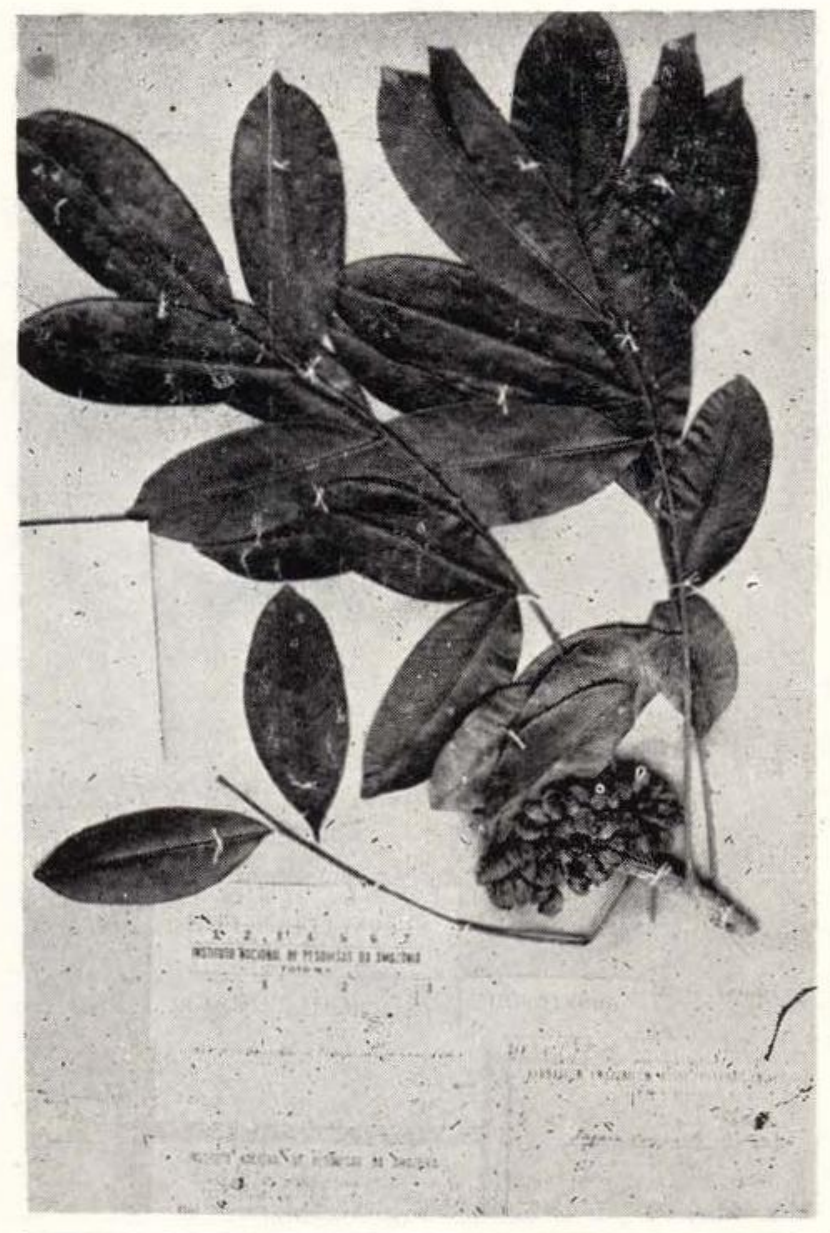

Foto 32. Zanthoxylum compactum (Huber ex Albuq.) Waterm. Ducke MG 10542 (holótipo).

isótipo RB 20501; parátipos: $M G 10905 \mathrm{fl}, R B$ $20500 \mathrm{fl}, 20502 \mathrm{fl} \mathrm{e} \mathrm{fr}, 25472 \mathrm{fl}$ ).

DISTRIBUIÇÃo - Das terras baixas da Colômbia até a parte ocidental do Pará, na Amazônia Central, Brasil. Habita em mata de várzea inundável da margem de rios e lagos ou em igapós. Coihida com flores em julho e com frutos de janeiro a novembro. BRASIL. Ama. zonas: Albuquerque \& L. Coelho $69-123 \mathrm{fr}$ (INPA); Fróes $26585 \mathrm{fr}$ (IAN); Mello 14 est (INPA); Prance et al. 3561 est (INPA); Rodrigues $8622 \mathrm{fr}$ (INPA); Silva et al. $310 \mathrm{fi}$ (INPA). Pará: Pires $3886 \mathrm{fr}$ (IAN). COLÔMBIA. Territorio Amazonas (rio Loreto-Yaco): Schultes \& Black $46-280 \mathrm{fr}$ (IAN). Fig. 16.

NOMES VULGARES - Brasil: Limãorana (Amazonas); Tamanqueira (Amazonas e Pará).
Zanthoxylum compactum distingue-se das demais espécies principalmente pelas inflorescências compactas.

16. 2. Zanthoxylum djalma-batistae (de Albuquerque) Waterm. Taxon $24(2 / 3)$ : 363. 1975. Fotos 33 e 34 .

Fagara djalma-batistae Albuq., Publ. INPA 27:9 tab. 7 e 8. 1968. Tipo. Ducke RB 35595. Brasil. Amazonas, Manaus, Colônia João Alfredo (holó. tipo).

Arvoreta até ca. de $8 \mathrm{~m}$ de altura; caule não ramificado, ereto, munido de acúleos com base muito dilatado-arredondada. Folhas aglomeradas no ápice do caule, imparipinadas, com 5-7 pares de folíolos, ca. de $76,5 \mathrm{~cm}$ de comprimento; pecíolo densamente coberto de

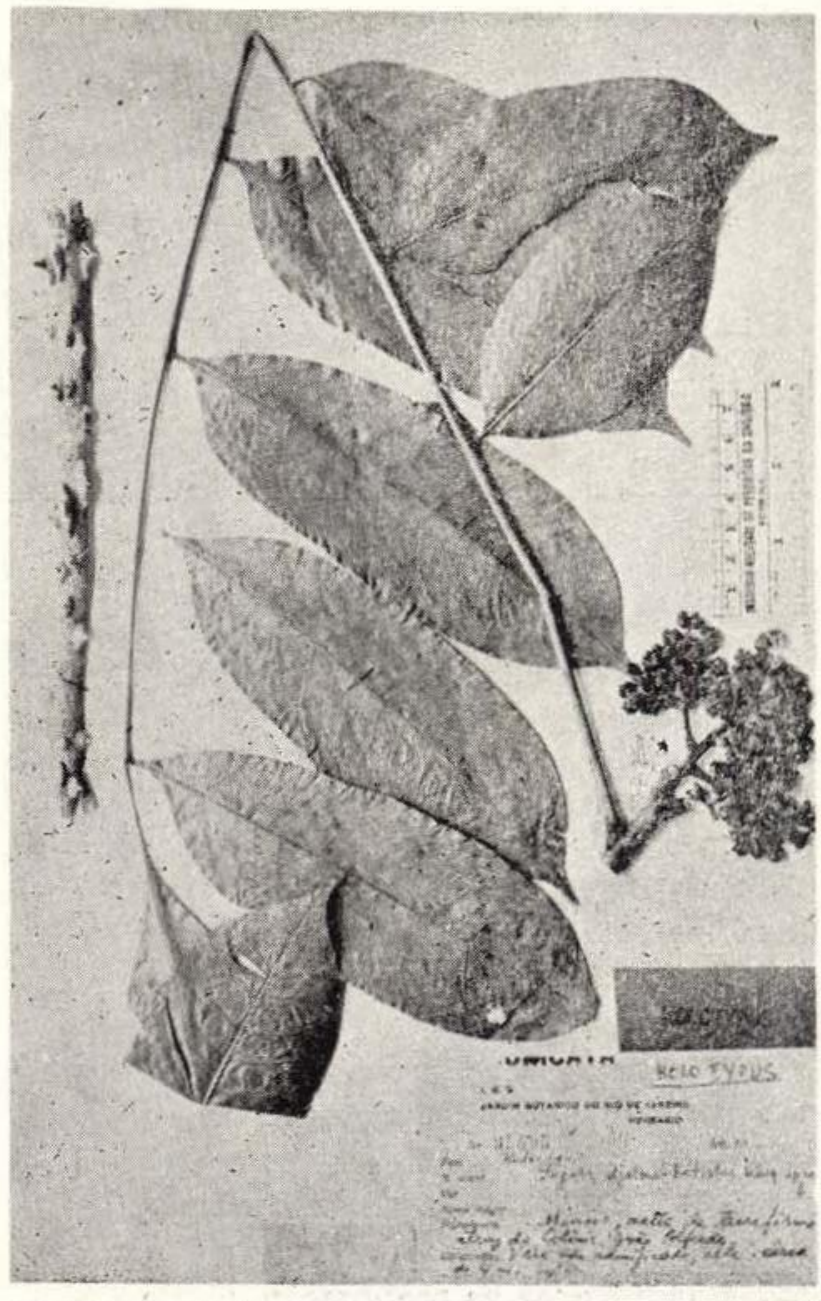

Foto 33. Zanthoxylum djalma-batistae (de Albuq.) Waterm. Ducke RB 35595 (holótipo). 


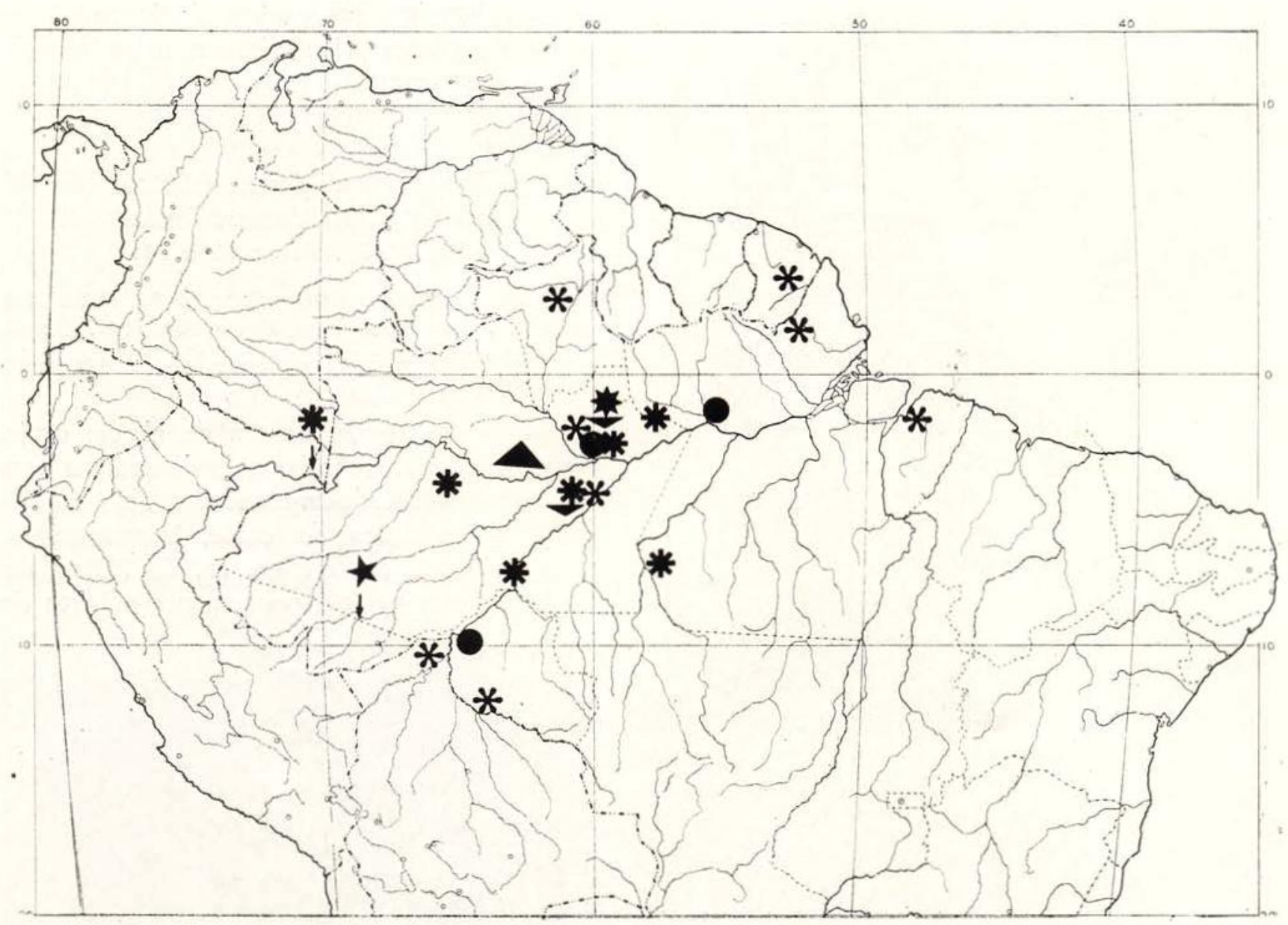

Fig. 16. Distribuição geográfica de * Zanthoxylum compactum, $\nabla$ Z. djalma-batistae, huberi *Z. machadoi, $*$ z. prancei e *Z. rhoifolium.

pêlos curtos; folíolos opostos, raro alternos, grandes, oblongo-elíticos, subcoriáceos, glabriúsculos por cima e densamente pilosos por baixo, subsésseis, base aguda, ápice acuminado, margem crenulada, glandulífera, ca. de $9,3-19,5 \mathrm{~cm}$ de comprimento e $3,8-7,1 \mathrm{~cm}$ de largura; nervura mediana proeminente em ambas as faces. Inflorescência em panículas angulosas, apicais, densamente cobertas de pêlos. Flores alvas, subsésseis; sépalas 5 , ovadotriangulares, agudas, imbricadas na prefloração, glabras por dentro e curtamente pilosas por fora, ca. de $0,5 \mathrm{~mm}$ de comprimento, margem franjada; pétalas 5 , oblongo-elíticas, côncavas, imbrieadas na prefloração, ca. de $1,5 \mathrm{~mm}$ de comprimento e $1 \mathrm{~mm}$ de largura, margem curtamente ciliada; flores masculinas: estames
5, glabros, alternipétalos, filetes atenuados, achatados, conectivo subgloboso, muito pequeno, anteras oblongas, esbranquiçadas; ovário rudimentar, bilocular, lóculos pequenos, dis postos sobre um ginóforo piloso; flores femininas desconhecidas. Fruto 1-5 cocas pequenas, subglobosas, unidas na base, ca. de $6 \mathrm{~mm}$ de comprimento e $4 \mathrm{~m}$ de largura, dispostas em ramos frutíferos paniculados, angulosos; semente 1, subglobosa, levemente carinada. nítida.

TIPOS - Ducke $s / n$. Brasil. Amazonas, Manaus, Colônia João Alfredo, fr (holótipo: RB 35595; parátipos: Ducke $s / n$. (IAN 43442), Byron 67-49 (INPA 20561), Rodrigues \& Loureiro 5826 (INPA 14778). 


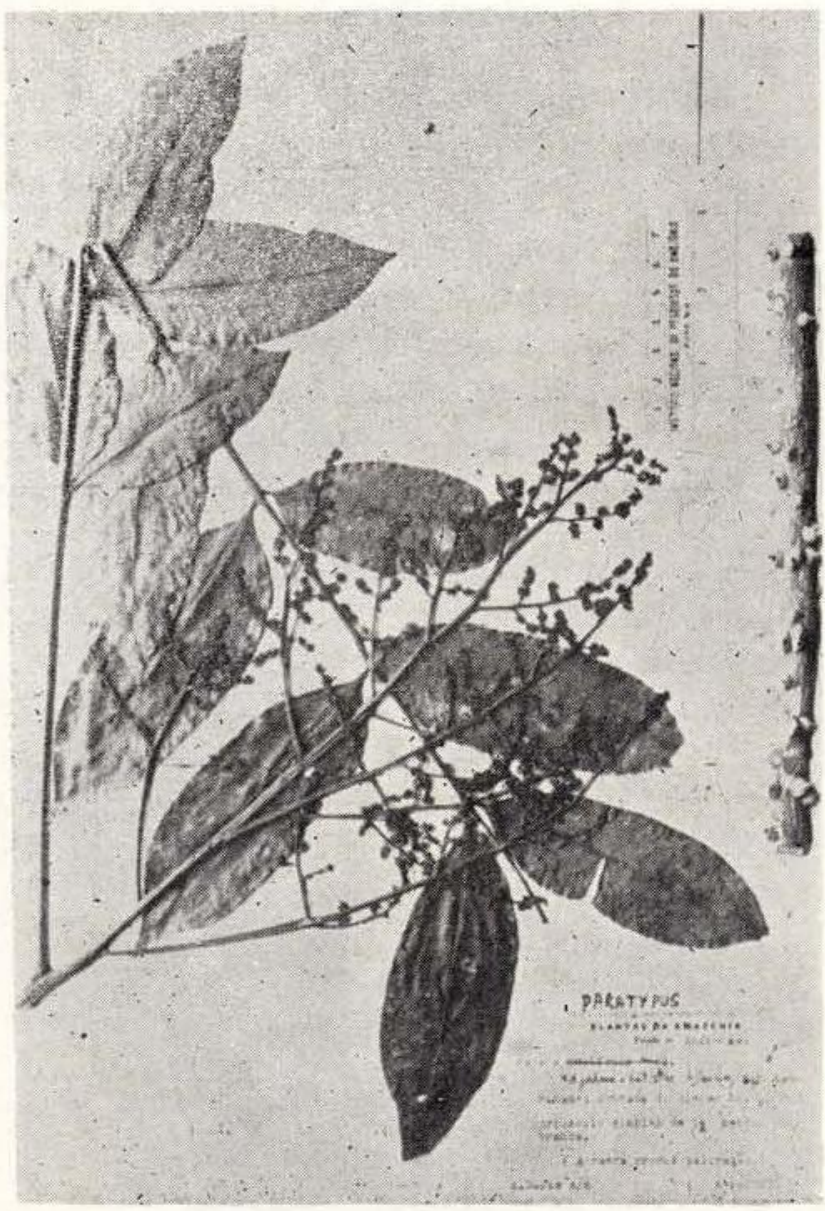

Foto 34. Zanthoxylum djalma-batistae (de Albuq.) Waterm. Ducke IAN 43442 (parátipo).

DISTRIBUIÇÃo - Parte oriental do Estado do Amazonas, na Amazônia Central, sendo mais freqüente na região de Manaus. Habita em mata primária de terra firme argilosa, úmida às vezes em capoeira. Colhida com tlores de setembro a fevereiro do ano seguinte e com frutos de abril a julho. BRASIL. Amazonas: Ducke IAN $43443 \mathrm{fl}$ (IAN); Mello INPA. $2003 \mathrm{fl}$ (INPA, MG); Prance et al. $3786 \mathrm{fl}$ (INPA, $\mathrm{MG}) ; 11408 \mathrm{fl}$ (INPA); Silva et al. $750 \mathrm{fr}$ (INPA); Silva \& Rodrigues $1949 \mathrm{fl}$ (INPA). Fig. 16.

A casca do tronco produz salivação, segundo informação de material herborizado (Ducke $s / n$ (IAN 43442, paratipo; IAN 43443).

Zanthoxylum djalma-batistae difere das demais espécies principalmente por ser arvoretc com o caule não ramificado.
16. 3. Zanthoxylum grazielae (de Albuquerque) Waterm., Taxon $24(2 / 3): 363$. 1975. Foto 35 .

Fagara grazielae Albuq., Publ. INPA 27:7, tab. 5. 1968. Tipo. Fróes 26556. Brasil. Amazonas, lago Badajós (holótipo: IAN 59715).

Árvore até $10 \mathrm{~m}$ de altura; ramos com pequenas manchas esbranquiçadas. Folhas glabriúsculas, imparipinadas, com 5 pares de folíolos; pecíolos pubérulos; folíolos freqüentemente subobovados, raro oblongo-elíticos, coriáceos, nítidos em ambas as faces, subsésseis, freqüentemente acuminados, raro de ápice retuso, base aguda, margem inteira. Inflorescência em panículas terminais, com ramificações angulosas. Flores masculinas amareladas, curtamente pediceladas; cálice pequeno,

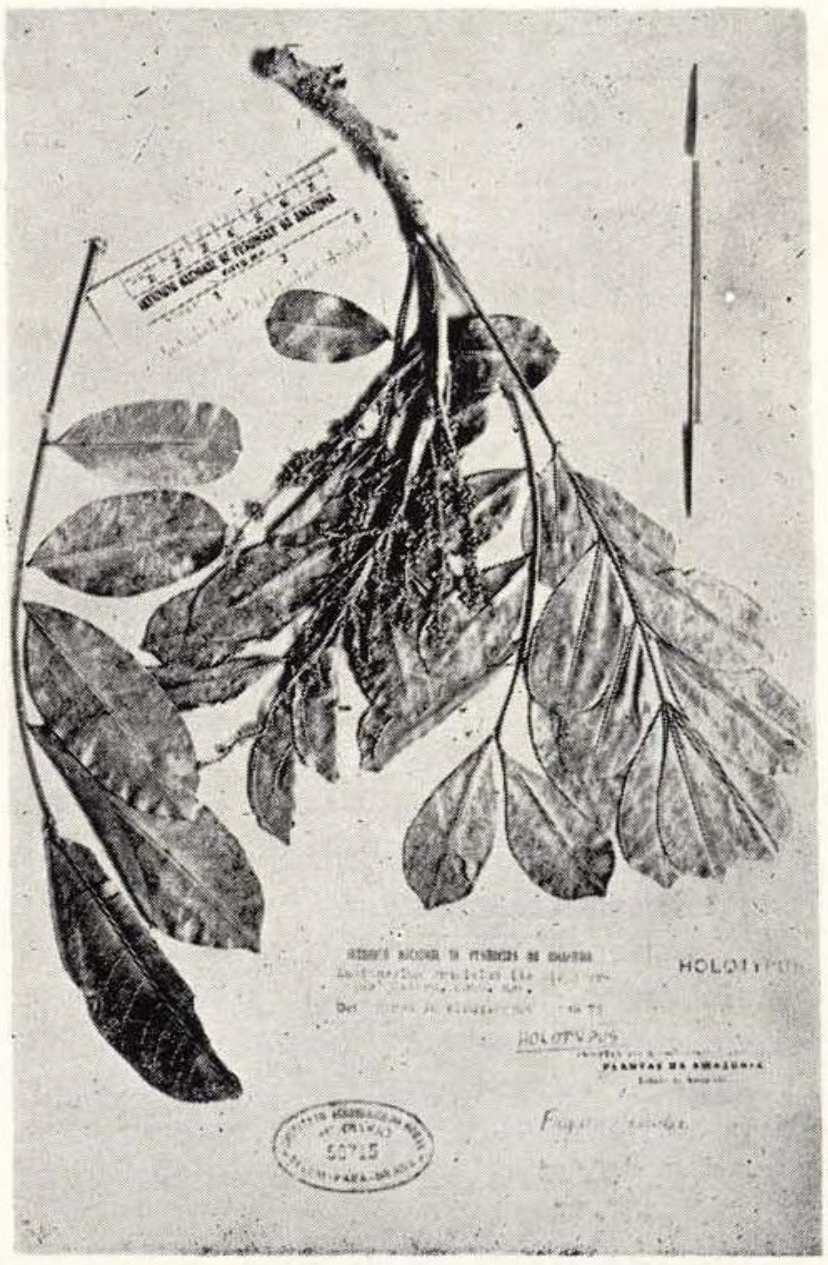

Foto 35. Zanthoxylum grazielae (de Albuq.) Waterman. Fróes (26556 (holótipo IAN), 
glabro por dentro e por fora, lacínios, 5, desiguais, com a margem curtamente ciliada; pétalas 5 , oblongo-elíticas, imbricadas na prefloração, vênula promínula em ambas as taces, ramificada; estames 5 , glabros, alternipétalos, filetes espessos, subtriangulares, conectivo pequeno, subgloboso, antera oblonga, avermelhada, com tecas sub-reniformes; ovário rudimer. tar, 3-4-locular, lóculos separados, estigmados, dispostos sobre um ginóforo. Flores femininas e frutos desconhecidos.

TIPo - Fróes 26556. Brasil. Amazonas, lago Badajós, fl (holótipo IAN 59715).

DISTRIBUição - Amazônia Ocidental, parte central do Estado do Amazonas. Habita em mata de margem de lago. Colhida com flores em setembro. Fig. 16.

Zanthoxylum grazielae difere das demais espécies principalmente pelos folíolos freqüentemente subobovados e anteras com tecas subreniformes.

16. 4. Zanthoxylum huberi Waterm., Taxon 24 $(2 / 3)$ : 366. 1975. Foto 36.

Fagara caudata Huber, Bol. Mus. Para. $5: 422$. 1909. Tipo. Ducke s/n. Brasil. Pará, rio Trombetas, Oriximiná (holótipo RB 20493).

Arbusto a árvore até $25 \mathrm{~m}$ de altura; ramos delgados, inermes. Folhas imparipinadas ou paripinadas, com $2-5$ pares de folíolos, pecíolos delgados, cilíndricos, inermes; foliolos opostos ou alternos, glabérrimos, peciolulados, ovado-lanceolados ou oblanceolados, base ligeiramente oblíqua, ápice caudado-acuminado. acúmen obtuso ou emarginado, margem subrevoluta, inteira, raro esparsa e obscuranientc crenada. Inflorescência em panículas axilares; ramificações subcilíndricas, curtamente pilosas e longitudinalmente rugosas. Flores alvas ou verde-esbranquiçadas, pediceladas; sépalas 5-6, ovado-triangulares, imbricadas; pétalas 5-6, oblongo-elíticas, glabras por fora e por dentro, imbricadas na prefloração; flores masculinas: estames 5-6, glabros, alternipétalos, inseridos na base do ovário rudimentar, filete achatado, atenuado, antera com conectivo apendiculado no ápice; flores femininas. ovário subgloboso, unilocular, glabro, estilete curto, lateral, estígma oblíquo-peltado. Fruxo unicoco, piriforme; semente subglobosa, levemente comprimida.

TIPO - Ducke $s / n$. Brasil. Pará, rio Trombetas, Oriximiná, fr (holótipo: RB 20493).

DISTRIBUIÇÃo - Do Território de Rondônia através do Amazonas até o Pará, na Amazônia Central. Habita em mata primária de terra firme argilosa ou argilo-silicosa, úmida, humosa. Colhida com flores em agosto-setembro e com frutos em dezembro. BRASIL. Amazonas: Aluisio $126 \mathrm{fl}$ (INPA); Rodrigues $5424 \mathrm{fl}$ (INPA, RB); $5463 \mathrm{fl}$ (INPA, RB); $5468 \mathrm{fl}$ (INPA). Pará: Ducke RB $20490 \mathrm{fl}$ (RB); RB $20491 \mathrm{fl}$ (RB); Fróes $31715 \mathrm{fr}$ (IAN). Território de Rondônia: Piance et al. $5454 \mathrm{fl}$ (INPA, NY). Fig. 16.

NOMES VULGARES - Brasil: Maruparana Manaus, Amazonas), tamanqueira da terra firme (Faro e Oriximiná, Pará).

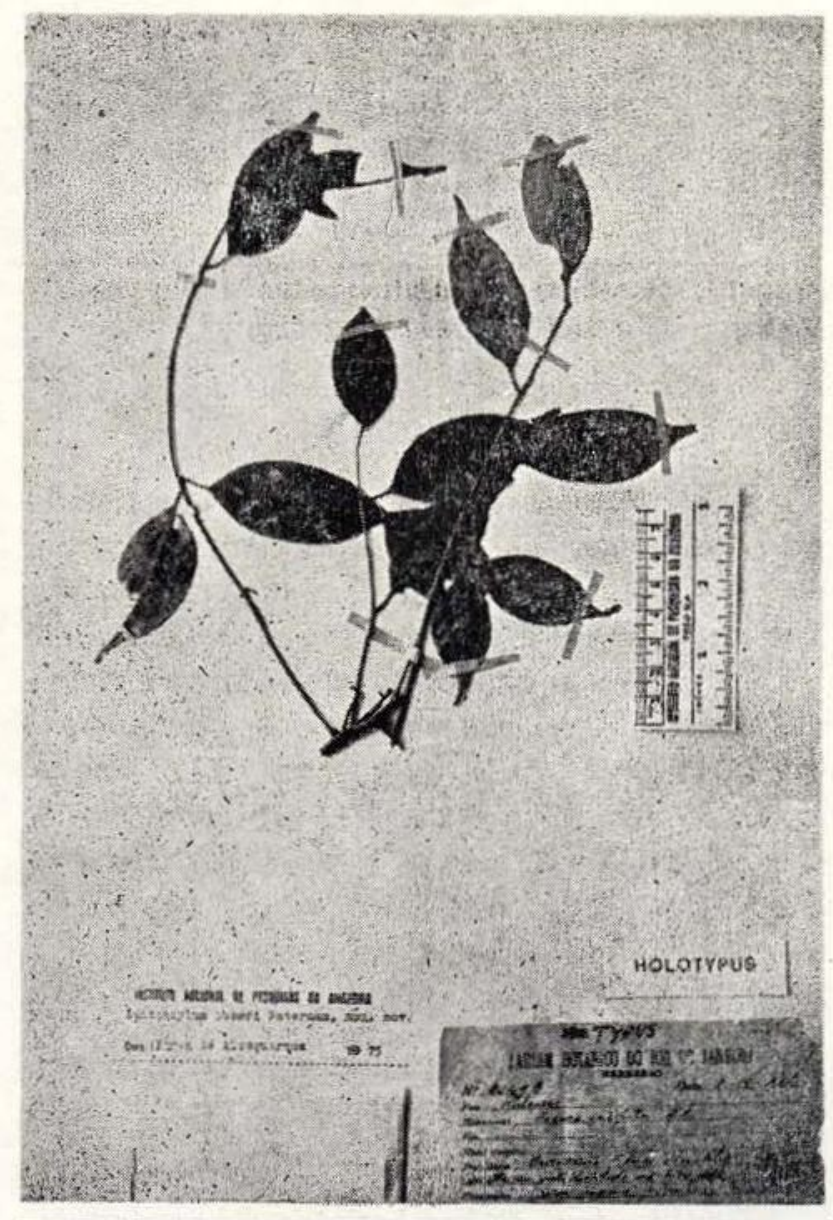

Foto 36. Zanthoxylum huberi Waterm. Ducke RB 20493, holótipo. 
Zanthoxylum huberi distingue-se das outras espécies por apresentar principalmente os folíolos ovado-lanceolados ou oblanceoladios de ápice caudado, ovário unilocular, estilete unilateral e fruto piriforme.

16. 5. Zanthoxylum machadoi (de Albuquerque) Albuquerque, comb. nov. Foto 37.

Fagara machadoi Albuq., Acta Amazonica 1(1) : 24. 1971. Albuquerque, Act. Amaz. 2(2) : 49.54, fig. 1. 1972. Tipo. Rodrigues 9000. Brasil. Amazonas, estrada Manaus-Itacoatiara, km 155 (holótipo INPA 28470).

Árvore grande até $30 \mathrm{~m}$ de altura e $45 \mathrm{~cm}$ de diâmetro de fuste (D.A.P.), muito esgalhaaa; tronco munido de poucos acúleos; rániu. cilindricos, densamente cobertos de acúleos. Folhas paripinadas, pilosas, com 3-10 pares ai folíolos, até ca. de $74,5 \mathrm{~cm}$ de comprimento; pecíolos cilíndricos, velutinos, munidos u acúleos, muito dilatados na base, até ca. de $59 \mathrm{~cm}$ de comprimento; folíolos grandes, alternos ou opostos, obiongo-elíticos, coriáceos, base desigual, aguda ou subobtusa ou obtusa ou subcordada, ápice acuminado, acúmen curto, glabriúsculos por cima, velutinos e verdeamarelados por baixo, peciolulados, margem ievemente crenulada, glandulifera, $7-19,5 \mathrm{~cm}$ de comprimento e $3,5-8 \mathrm{~cm}$ de largura. Flores masculinas e femininas desconhecidas. Fruto 1-3 cocas conchiformes, subglcbosas, superfície áspera, curtamente pilosas, dispostas em ramos frutíferos paniculados, terminais, curtos, com ramificações subquadrangulares, articuladas, suberoso-rugosas, curtamente pilosas: semente 1, subglobosa, levemente carinada, testa muito nítida.

TIPO - Rodrigues 9000. Brasil. Amazonas, estrada Manaus-Itacoatiara, km 155, fr (holótipo: INPA 28470).

DISTRIBUIÇão - Região de Manaus, parte oriental do Estado do Amazonas na Amazônia Central. Habita em mata primária de terra firme argilosa, úmida. Colhida apenas uma vez com frutos em fevereiro. Fig. 16 .

Zanthoxylum machadoi tem afinidade com Z. djalma-batistae, mas separa-se dela por ser árvore grande, alta, de copa muito esgaihada e apresentar o pecíolo, peciólulo e face inferior

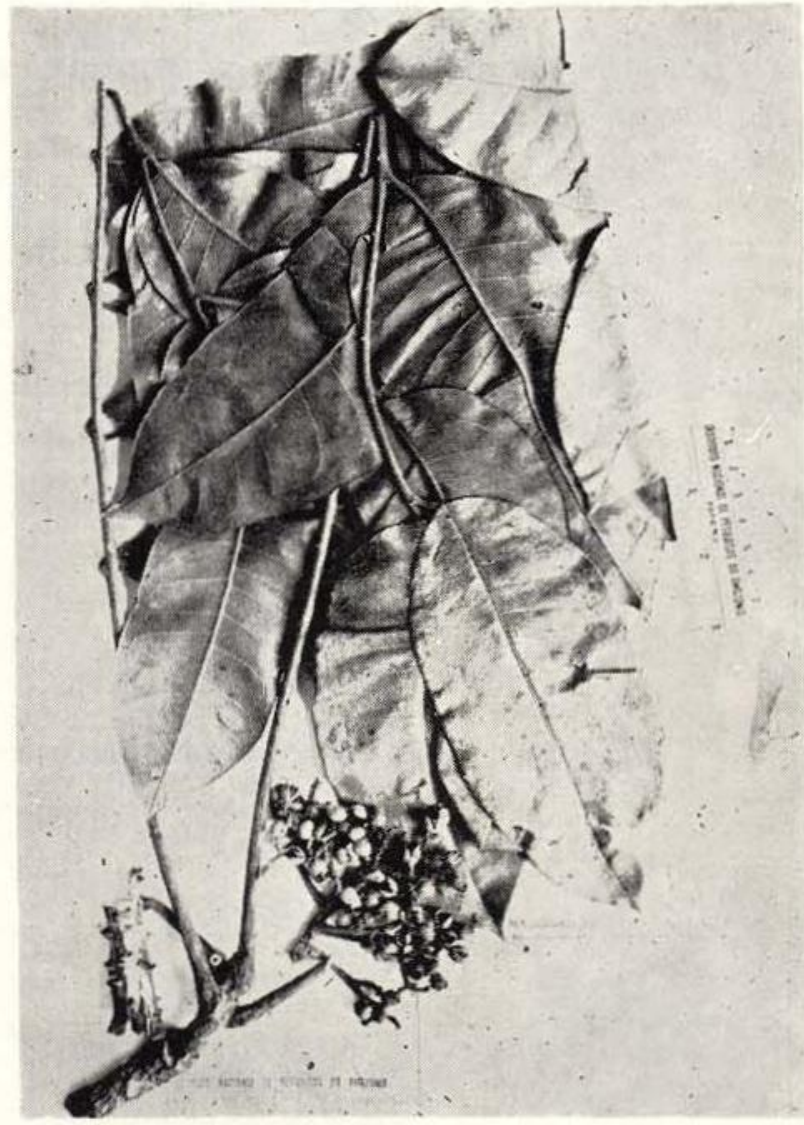

Foto 37. Zanthoxylum machadoi (de Albuq.) Albuq. Rodrigues 9000 (holótipo INPA).

dos folíolos velutinos, base dos folíolos algumas vezes subobtusa, obtusa ou subcordada, inflorescência com ramificações subquadrandulares, articuladas, suberoso-rugosas e cocas maicres, segundo Albuquerque (1971 e 1972). Distingue-se das demais espécies principalmente pela pilosidade velutina nas folhas, folíolos com base de aguda a subcordada 0 infrutescência com ramificações subquadrandulares, articuladas e suberoso-rugosas.

16. 6. Zanthoxylum prancei (de Albuquerque) Waterm., Taxon 24 (2/3): 364. 1975. Foto 38.

Fagara prancei Albuq., Bol. INPA, Pesq. Flor 8:1, fig. 1. 1970. Tipo. Prance 7887. Brasil. Amazonas, confluência do rio Iaco com o rio Purus (holótipo: INPA 24686; isotipo: MG, NY, $\mathrm{R}$ e US)

Árvore até $20 \mathrm{~m}$ de altura. Folhas paripinadas, com 3-5 pares de folíolos, pecíolos mais 
ou menos angulosos, subcilíndricos na base; folíolos oblongo-elíticos, raro elíticos, membranáceos, base aguda, desigual, ápice acuminado, margem inteira, levemente decurrente nos peciólulos longos. Flores masculinas e femininas desconhecidas. Fruto 1-4 cocas sublobosas, pequenas, angulosas, dispostas em ramos frutíferos paniculados, axilares, subcilíndricos, densamente cobertos de pêlos curtos, até ca. de $13,5 \mathrm{~cm}$ de comprimento; semente 1 , subglobosa, levemente carinada.

İipos - Prance 7387. Brasil, Amazonas, confluência do rio laco com o rio Purus, $\mathrm{fr}$ (holótipo INPA 24686); isótipo: MG, NY, R e US; parátipo: Fróes 23509 (IAN 42166).

DISTRIBUIÇÃo - Do sul do Amazonas, fronteira com o Acre, até a parte oriental do Pará.

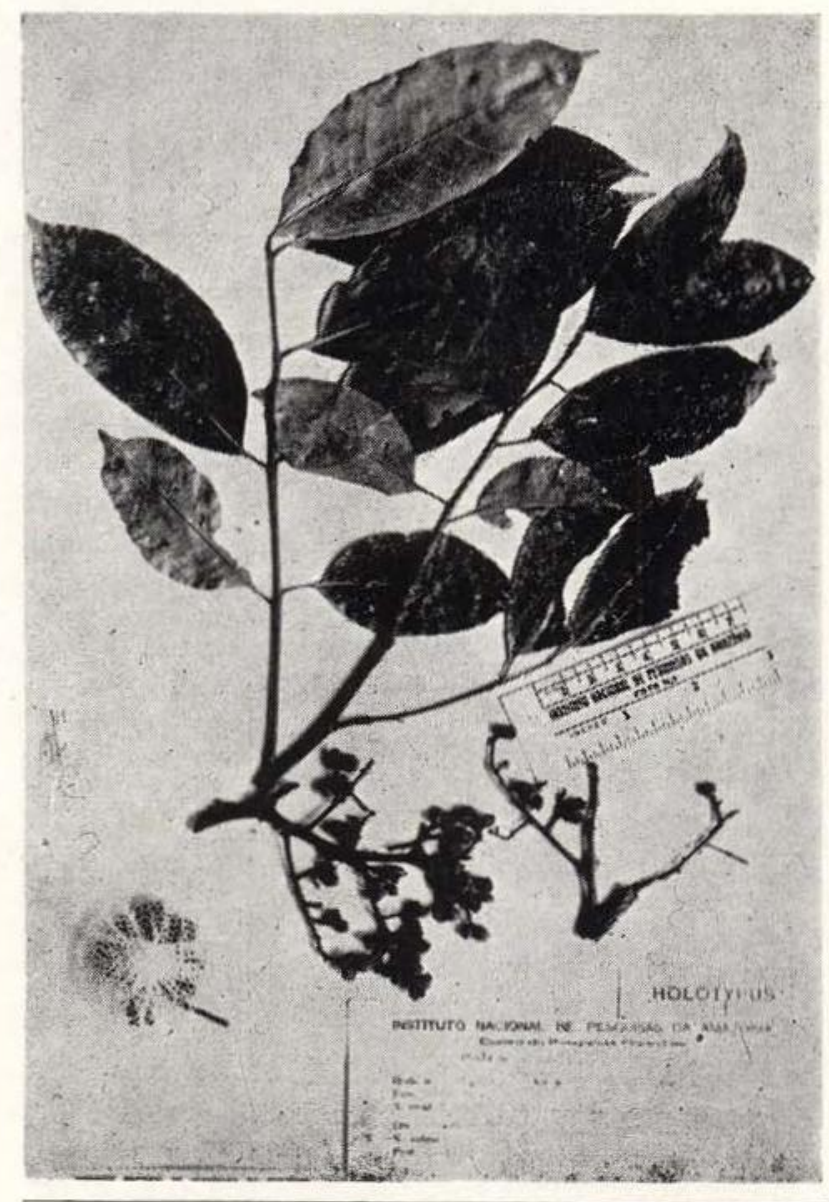

Foto 38. Zanthoxylum prancei (de Albuq.) Waterm. Prance et al. 7887 (holótipo INPA).

$(\bullet)$ - Sinônimos citados por Engler (1874).
Habita em mata primária de terra firme. CoIhida com frutos em setembro-oututbro. Fig. 16.

Zanthoxylum prancei distingue-se das outras espécies por apresentar principalmente cocas angulosas.

$\mathrm{Na}$ etiqueta em inglês do exemplar INPA 24686 (holótipo) Zanthoxylum prancei está citada para o Estado do Acre, porém houve algum engano, pois, por ocasião de sua descrição, o seu coletor comunicou-nos ser a mesma procedente do Estado do Amazonas, próximo à fronteira com aquele Estado.

16. 7. Zanthoxylum rhoifolium Lamarck, Encyc. Method. Botanique 2 (2): 39. 1786; Engler, in Mart. FI. Bras. 12 (2): 174. 1874. Fotos 39 e 40.

Fagara rhoifolia (Lam.) Engl., in Engler \& Prantl. Nat. Pflanzenf., 3(4) : 118. 1896 e 2a ed 19a: 220. 1931. Lemée, Fl. Gui. Franç $2: 180$. 1952. Cowan, Sellowia 12:82. 1960. Albuquerque, An. Acad. brasil. Ci. 40(4) : 502, est. I, fig. 1. 1968; Bol. INPA, Pesq. Flor. 13:7-8, fig. 6, C e D. 1970 .

Langsdorfia instrumentaria Leand. Sacram. Denkschr. Akad. Müench. 12 : 229. 1819. (*) Pohlana instrumentaria Nees \& Mart., Nov. Act. Nat. Cur. 12(1): 17. 1823. (*)

Zanthoxylum langsdorfii St. Hil., Fl. Bras. Mer. 1: 76. 1825. (")

Zanthoxylum perrotteti A. DC., Prodromus, 1: 726. 1824. (*)

Zanthoxylum sorbifolium St. Hil., Fl. Bras. Mer. 1: 75, tab. 15. 1825. (")

Arbusto a árvore até $15 \mathrm{~m}$ de altura; caule muito aculeado. Folhas imparipinadas ou abruptamente pinadas, densamente aglomeradas para o ápice dos ramos, membranáceas, esparsamente cobertas de pêlos estrelados em ambas as faces ou mais densamente pilosas na face inferior, 3-17 pares de folíolos, pecíolos munidos de acúleo; folíolos pequenos, alternos ou opostos, estreitamente elíticos ou elíticos, base levemente obtusa ou atenuadoaguda, subséssil, ápice obtuso ou agudo, margem mais ou menos profundamente crenada ou crenado-serrada, até ca. de $5,4 \mathrm{~cm}$ de comprimento e $2,2 \mathrm{~cm}$ de largura; nervura mediana 
provida de acúleo ou inerme. Inflorescência em panículas terminais, axilares e extra-axilares, compostas, multifloras, curtas. Flores esverdeadas ou alvas, tetrâmeras a pentâmeras, pedicelos curtos, mais ou menos densamente coiertos de pêlos estrelados; cálice com lacínios triangular-agudos; pétalas oblongo-elíticas, agudas em ambas as extremidades, glabras ou parcialmente cilioladas; flores masculinas: estames o dobro do comprimento das pétalas, ovário rudimentar; flores femininas: cvário 1-3-locular, lóculos subglobosos, sobre um disco espesso, estígma subséssil, obliquo ou coroado-peltado. Fruto freqüentemente 1 coca; cocas pequenas, subglobosas, inicialmente esverdeadas passando a avermelhadas até atingir a côr castanha na maturidade, esparsamente cobertas de giândulas oleíferas.

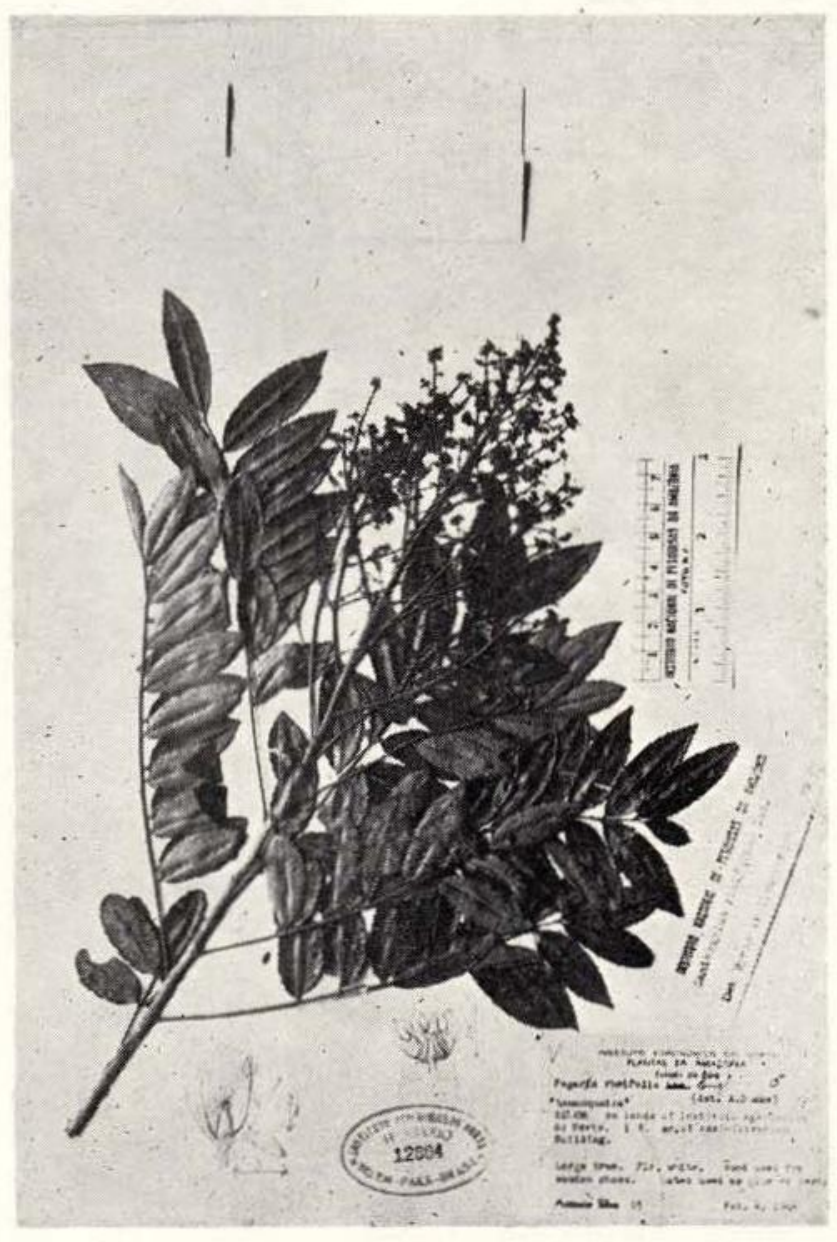

Foto 39. Zanthoxylum rhoifolium Lam. Silva 83 (IAN).

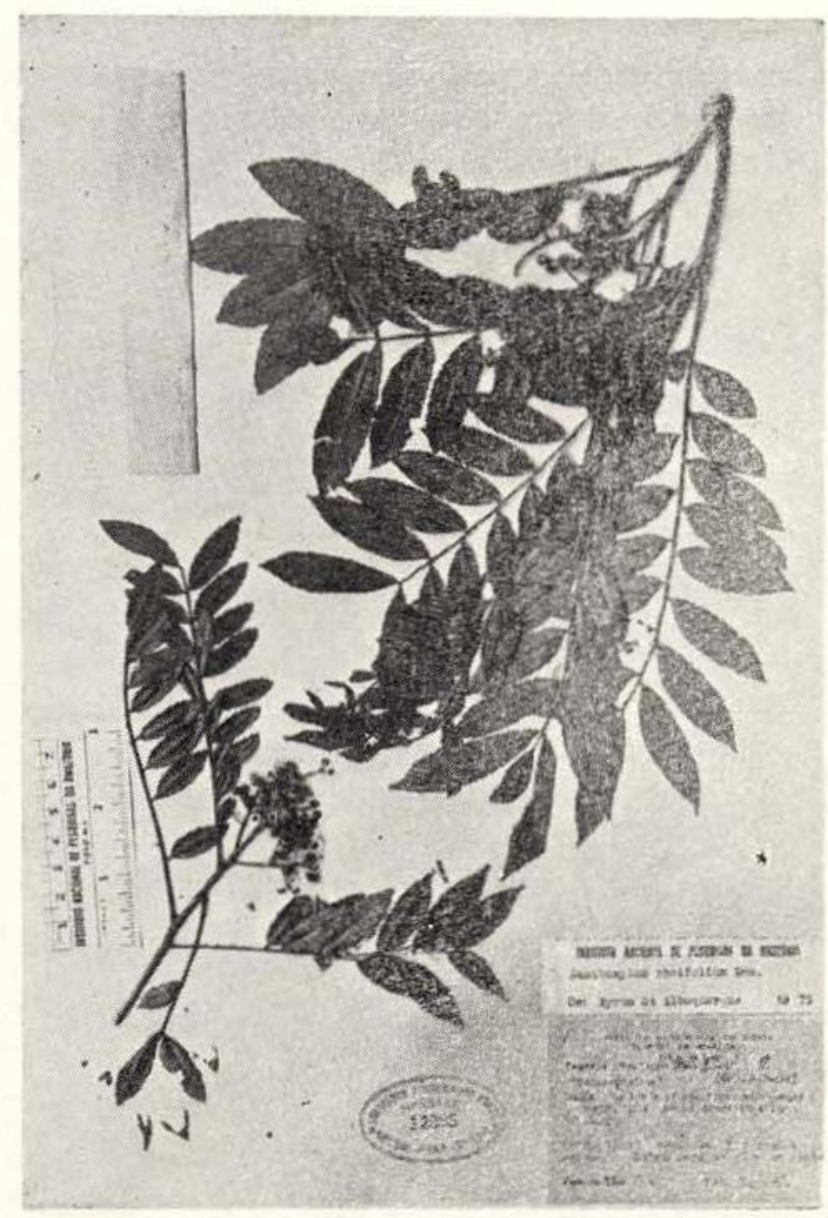

Foto 40. Zanthoxylum rhoifolium Lam. Silva 83a (IAN).

TIPO - (holótipo: P, n. v.).

Distribuição - Em todo o Brasil, na Bolivia e na Guiana Francesa. Habita em mata primária e secundária de terra firme de solo argiloso ou argilo-silicoso, úmido. Colhida com flores e frutos de janeiro a dezembro. BOLIVIA. Estado de Pando: Prance et al. $8359 \mathrm{tı}$ (INPA). BRASIL. Amazonas: Almeida INPA $339 \mathrm{fr}$ (INPA); INPA $2096 \mathrm{fr}$ (INPA); Loureiro et al. INPA $37503 \mathrm{fr}$ (INPA). Pará: Archer 7945 $\mathrm{fl}$ (IAN); $8257 \mathrm{fr}$ (IAN); Capucho $498 \mathrm{fl}$ (IAN); Ducke MG $474 \mathrm{fr}$ (MG); MG $10579 \mathrm{fr}$ (MG); MG $11490 \mathrm{fl}$ (MG); Guedes $316 \mathrm{fr}$ (IAN); Silva $83 \mathrm{fl}$ (IAN); 83a fr (IAN). Território do Amapá: Irwin et al. $48487 \mathrm{fl}$ e fr (IAN); Ledoux 57-1111 $\mathrm{fr}$ (MG). Território de Rondônia: Rodirigues \& Albuquerque $4241 \mathrm{fl}$ (INPA). Fig. 16.

Nomes vUlgares - Brasil: Carne de Anta (Manaus); Limãozinho (Manaus; Amapá); Ta- 
manqueira, Tamanqueira da terra firme (Manaus: Pará; Amapá); Tamanqueira de espinho (Pará); Maminha de porca, Juvevê, Espinho de vintém, Tamanqueiro, Tembetaru, Tinguaciba (sudeste do Brasil) .

usos - A madeira, segundo Loureiro \& Silva (1968), é utilizada para a confecção de tamancos, cabos de ferramentas, carroçaria e marcenaria, e LeCointe (1947) salienta que a mesma possui um rendimento na produção de celulose da ordem de $45,1 \%$. De acordo com informação de material de herbário (IAN 11556), a madeira tem o odor da baunilha (Vanilla sp. - Orchidaceae) A casca do tronco é usada como estimulante, estomáquica e digestiva, bem como a raiz é amarga com propriedades tônicas, segundo LeCointe (1947).

Zanthoxylum rhoifolium distingue-se das demais espécies principalmente pelas folhas cobertas por pilosidade estrelada, folíolos muito menores e margem profundamente crenada ou crenado-serrada.

Var. sessilifolium Engler, in Mart. FI. Bras. 12 (2): 176. 1874.

Folhas em geral 7-15 pares de folíolos esparsamente cobertos de pêlos estrelados; folíolos oblongos de base oblíqua, séssil e ápice obtuso ou pouco agudo.

VARIEDADE Tí́PICA - (não localizada).

DISTRIBUIÇÃo - Estado do Amazonas, região do rio Solimōes, Spruce 1582 (Engler, 1874). Esta variedade também está assinalada por Engler (1874) para os Estados de Mato Grosso, Piauí, Minas Gerais e sul da Bahia, bem como para a República da Guiana e Guiana Francesa. 


\section{SUMMARY}

Our curiosity about the Rutaceae arose due to its confused taxonomy, the number of taxa increased without order with several papers, descriptions of new genera and species in dispersed literature without a monograph of the family since Engler (1896 and 1931).

In the State of Amazonas, Brazil, there are 16 genera belonging to the Rutaceae with 29 species (including 2 varieties), whose externai characteristic features are sufficiently distinct to allow the intergeneric and interespecific separation of the studied taxa. The genera that occur in our region are Adiscanthus, Cusparia, Decagonocarpus, Erythrochiton, Esenbeckia, Galipea, Hortia, Leptothyrsa, Monnieria, Myllanthus, Nycticalanthus, Raputia, Ravenia, Spathelia, Ticorea e Zanthoxylum.

Ecologically, the family Rutaceae occurs in many kinds of habitats. For example, the species Adiscanthus fusciflorus is found in highland campina and campina forest, and in highiand primary and secondary forests. This shows the adaptability of the species in different ecological habitats.

Within the family internal glands are developed which secrete a strongly aromatic oil whose ecological role, according to Haberlandt (1928), probably provides additional protection to the plants against the attack of predators.

The woods of the Rutaceae are utilized for several economical purposes and special reference should be given to the species Euxylophora paraensis Huber ("pau amarelo") whose wood is used in the timber industry mainly for parquets, according to Loureiro \& Silva (1968). Another species of economical value for the pulp and paper industry is Zanthoxylum rhoifolium Lamarck ("tamanqueira da terra firme") whose wood produces a cellulose yield about $45,1 \%$, as stated by LeCointe (1947).

Keys for identification of the genera and species are presented. 40 photographs of the 29 species of the 16 studied genera and 16 figures iliustrate this work. 


\section{$A P E N D I C E$}

\section{INDICE DOS GENEROS}

Pág.

\begin{tabular}{|c|c|}
\hline ÍNDICE DOS GENEROS & $\ldots \quad 45$ \\
\hline $\begin{array}{lll}\cdots & \cdots & 12 \\
\cdots & \cdots & 14\end{array}$ & Spathelia ........................ 45 \\
\hline $\begin{array}{lll} & \end{array}$ & Spiranthera $\ldots \ldots \ldots \ldots \ldots$ \\
\hline $\begin{array}{lll} & \\
\ldots \ldots \ldots \ldots \ldots \ldots & \ldots & 40 \\
\ldots \ldots \ldots \ldots \ldots & \ldots & 33\end{array}$ & Systemon .... \\
\hline $\begin{array}{ll}\ldots \ldots \ldots \ldots \ldots \ldots \ldots & 33 \\
\ldots \ldots \ldots \ldots \ldots \ldots \ldots \ldots & 49\end{array}$ & Ticorea ....................... 24,47 \\
\hline (4. & 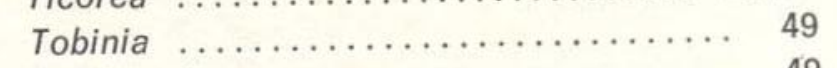 \\
\hline 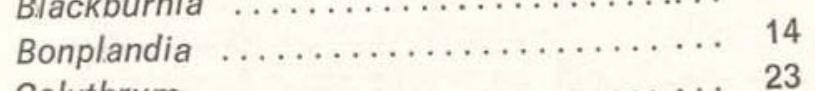 & 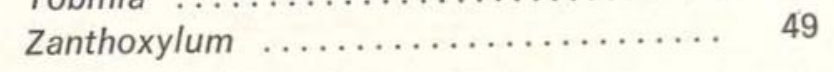 \\
\hline $\begin{array}{l}\text { Colythrum } \ldots \ldots \ldots \ldots \ldots \ldots \ldots \ldots \ldots \ldots \ldots \ldots \ldots \ldots \ldots \ldots \ldots \ldots \ldots \ldots \\
\text { Conchocarpus } \ldots \ldots \ldots \ldots \ldots \ldots\end{array}$ & \\
\hline 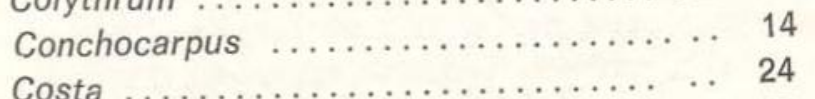 & ÍNDICE DOS NOMES CIENTÍFICOS \\
\hline $\begin{array}{llll}\text { Costa } \ldots \ldots \ldots \ldots \ldots \ldots \ldots \ldots \ldots \ldots & 24 \\
49\end{array}$ & \\
\hline $\begin{array}{lll}\text { Curtisia } & \ldots \ldots \ldots \ldots \ldots \ldots \ldots \ldots \ldots \ldots & 49 \\
14\end{array}$ & Adiscanthus \\
\hline $\begin{array}{llll}\text { Cusparia } \ldots \ldots \ldots \ldots \ldots \ldots \ldots \ldots \ldots \ldots \ldots & & 14 \\
14\end{array}$ & fusciflorus \\
\hline 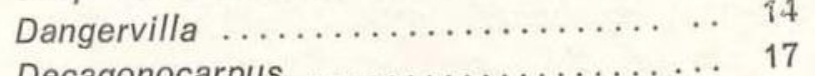 & Aubletia \\
\hline $\begin{array}{l}\text { Decagonocarpus } \ldots \ldots \ldots \ldots \ldots \ldots \ldots \ldots \\
\text { Diglottis } \ldots \ldots \ldots \ldots \ldots \ldots \ldots \ldots \ldots \ldots \ldots\end{array}$ & trifoliata ... \\
\hline $\begin{array}{lllll}\text { Diglottis } & \ldots \ldots \ldots \ldots \ldots \ldots \ldots \ldots \ldots \ldots & \ldots & \\
\text { Diomma } & \ldots \ldots \ldots \ldots \ldots \ldots \ldots \ldots \ldots \ldots \ldots & \ldots & 45\end{array}$ & Cusparia \\
\hline $\begin{array}{l}\text { Diomma } \ldots \ldots \ldots \ldots \ldots \ldots \ldots \ldots \ldots \ldots \ldots \ldots \ldots \ldots \ldots \ldots \ldots \ldots \ldots \ldots \ldots \\
\text { Endostephium } \quad \ldots \ldots \ldots \ldots \ldots \ldots\end{array}$ & febrifuga ........ \\
\hline 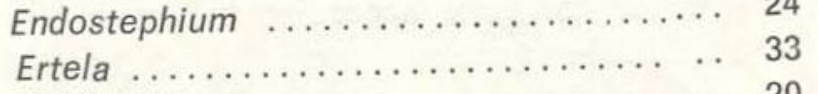 & magdalenensis .. \\
\hline 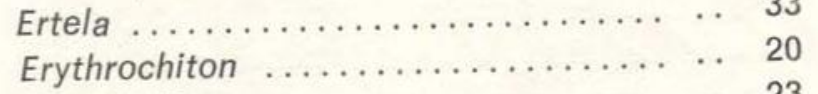 & ramiflora...... \\
\hline $\begin{array}{lllll}\text { Erythrochiton } & \ldots \ldots \ldots \ldots \ldots \ldots \ldots \ldots \ldots & \ldots & 20 \\
\text { Esenbeckia } & \ldots \ldots \ldots \ldots \ldots \ldots \ldots \ldots \ldots \ldots & \ldots & 23\end{array}$ & toxicaria ............. \\
\hline $\begin{array}{l}\text { Esenbeckia } \ldots \ldots \ldots \ldots \ldots \ldots \\
\text { Evodia } \ldots \ldots \ldots \ldots \ldots \ldots \ldots\end{array}$ & trombetensis ....... \\
\hline $\begin{array}{lll}\text { Fagara } & \ldots \ldots \ldots \ldots \ldots \ldots \ldots \ldots \ldots \ldots \ldots \ldots \ldots \ldots \ldots \ldots \ldots \ldots \ldots \ldots \ldots \ldots & 49 \\
24\end{array}$ & 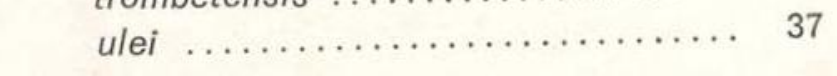 \\
\hline 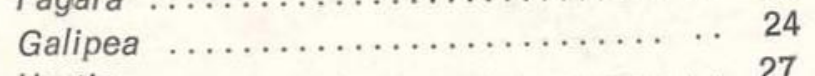 & Decagonocarpus \\
\hline 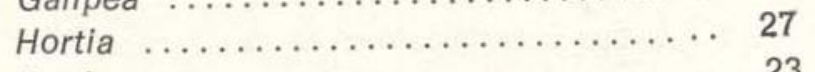 & $\begin{array}{l}\text { Decagonocarpus } \\
\text { cornutus ............ }\end{array}$ \\
\hline 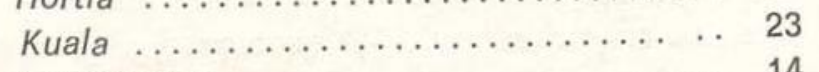 & 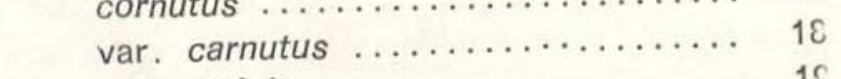 \\
\hline Lasiostemon ................. & $\begin{array}{l}\text { var. carnutus } \\
\text { oppositifolius } \ldots \ldots \ldots \ldots \ldots \ldots \ldots\end{array}$ \\
\hline $\begin{array}{llll}\text { Lemonia } & \ldots \ldots \ldots \ldots \ldots \ldots \ldots \ldots \ldots & 42\end{array}$ & Erythrochiton \\
\hline Leptothyrsa $\ldots \ldots \ldots \ldots \ldots \ldots \ldots \ldots \ldots \ldots \ldots$ & $\begin{array}{l}\text { Erythrochiton } \\
\text { brasiliensis }\end{array}$ \\
\hline Monnieria $\ldots \ldots \ldots \ldots \ldots \ldots \ldots \ldots \ldots \ldots$ & Esenbeckia \\
\hline Myllanthus ......................... 36 & cornuta ........ \\
\hline Nycticalanthus ..................... 38 & pilocarpoides ...... \\
\hline Obentonia ........................ 14 & Fagara \\
\hline Ochroxylum ....................... 49 & $\begin{array}{l}\text { Fagara } \\
\quad \text { caudata }\end{array}$ \\
\hline Ozophyllum $\ldots \ldots \ldots \ldots \ldots \ldots \ldots \ldots \ldots$ & $\begin{array}{l}\text { caudata } \ldots \ldots \ldots \\
\text { compacta } \ldots \ldots \ldots\end{array}$ \\
\hline Pentamorpha ................... 20 & $\begin{array}{l}\text { compacta } \ldots \ldots \ldots \\
\text { djalma-batistae } \ldots\end{array}$ \\
\hline Pholidandra .................... 40 & $\begin{array}{l}\text { djalma-batistae } \ldots . . . \\
\text { grazielae } \ldots . . . . .\end{array}$ \\
\hline Pohlana ....................... 49 & $\begin{array}{l}\text { grazielae } \ldots \ldots \ldots \\
\text { machadoi } \ldots \ldots \ldots\end{array}$ \\
\hline Polembryum .................. 23 & $\begin{array}{l}\text { machadoi } \ldots \ldots \ldots \\
\text { prancei } \ldots \ldots \ldots \ldots\end{array}$ \\
\hline Raputia ......................... 40 & $\begin{array}{l}\text { prancei } . . . \ldots \ldots \ldots \\
\text { rhoifolia } \ldots \ldots \ldots \ldots\end{array}$ \\
\hline Ravenia .......................... 42 & $\begin{array}{l}\text { rhoifolia } \ldots \ldots \ldots \\
\text { Galipea }\end{array}$ \\
\hline Rossenia ........................ 14 & $\begin{array}{l}\text { Galipea } \\
\quad \text { grandifolia ... }\end{array}$ \\
\hline$\ldots \ldots \ldots \quad \ldots \quad 45$ & \\
\hline
\end{tabular}


Pág.

Hortia

brasiliensis ................ 27

coccinea ................. 28

duckei .................... 29

excelsa ................. 31

longifolia ................... 29

superba $\ldots \ldots \ldots \ldots \ldots \ldots \ldots \ldots \ldots$

Langsdorfia

instrumentaria

56

Leptothyrsa

sprucei

32

Monnieria

trifolia

Myllanthus

maroana

ulei

Nycticalanthus

speciosus

Pentamorpha

graveolens

Pohlana

instrumentaria

Raputia

aromatica ................ 40

magnifica .................. 13

paraensis .................. 42

sigmatanthus ............... 42

subsigmoidea ............... 41
Pág.

Ravenia

biramosa $\ldots \ldots \ldots \ldots \ldots . \ldots . \ldots . \ldots 4$

infelix ................... 42

pseudalterna ................ 43

Sciuris

corymbosa ................. 26

trifoliata .................. 26

Sohnreyia

excelsa ..................... 45

Spathelia

excelsa .................. 45

simplex $\ldots \ldots \ldots \ldots \ldots \ldots \ldots \ldots \ldots \ldots$

Ticorea

foetida .................. 48

longiflora ................ 48

Zanthoxylum compactum ................ 50

djalma-batistae ............... 51

fraxineum ................... 49

grazielae ................. 53

huberi ..................... 54

langsdorfii $\ldots \ldots \ldots \ldots \ldots \ldots \ldots \ldots \ldots$

machadoi ................... 55

perrotteti ................. 56

prancei ................... 55

rhoifolium ................. 56

var. sessilifolium ............ 58

sorbifolium ............... 56 


\section{INDICE DOS TAXA}

Pág.

Adiscanthus fusciflorus Ducke ....................... 12

Cusparia ramiflora Spruce ex Engler ..................... 14

Cusparia toxicaria Spruce ex Engler ..................... 15

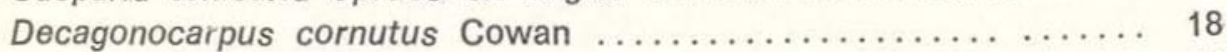

var. cornutus ................................ 18

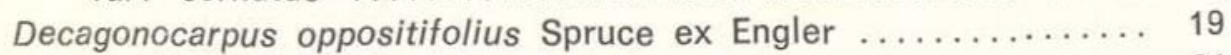

Erythrochiton brasiliensis Nees \& Martius ................. 21

Esenbeckia cornuta Engler .......................... 23

Galiper grandifolia Engler ........................... 25

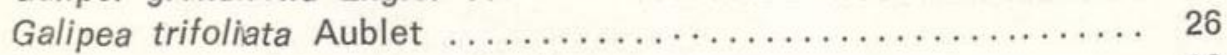

Hortia coccinea Spruce ex Engler ..................... 28

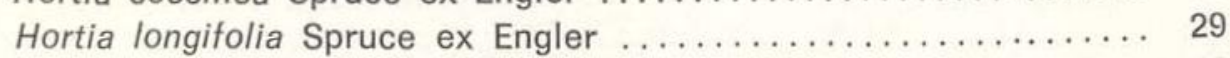

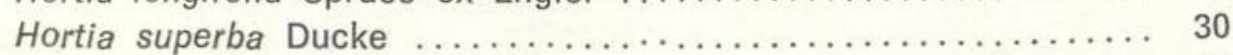

Leptothyrsa sprucei Hooker f. ....................... 32

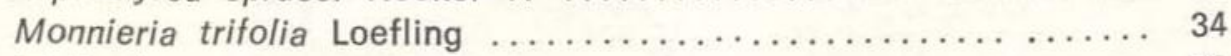

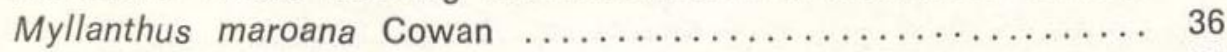

Myllanthus ulei (Krause) Cowan ....................... 37

Nycticalanthus speciosus Ducke ..................... 39

Raputia subsigmoidea Ducke ........................ 41

Ravenia biramosa Ducke .......................... 43

Ravenia pseudalterna Ducke ........................ 43

Spathelia excelsa (Krause) Cowan \& Brizicky .............. 45

Ticorea longiflora DC. ......................... 48

Zanthoxylum compactum (Huber ex Albuquerque) Waterm....... 50

Zanthoxylum djalma-batistae (de Albuquerque) Waterm. ........ 51

Zanthoxylum grazielae (de Albuquerque) Waterm. ............. 53

Zanthoxylum huberi Waterm. ....................... 54

Zanthoxylum machadoi (de Albuquerque) Albuquerque ......... 55

Zanthoxylum prancei (de Albuquerque) Waterm. .............. 55

Zanthoxylum rhoifolium Lamarck ..................... 56

var. sessilifolium Engler ....................... 58 


\section{ÍNDICE DOS NOMES VULGARES}

Pag.

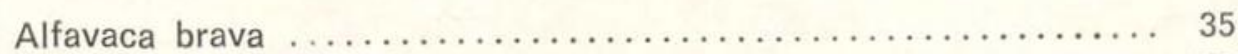

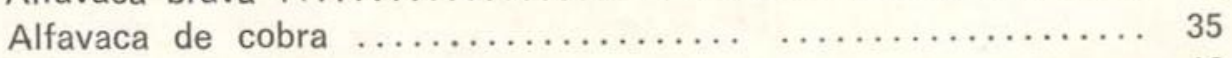

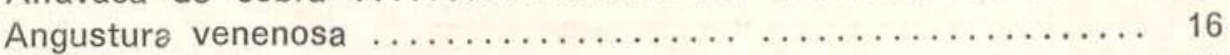

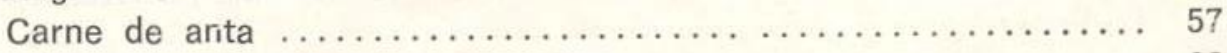

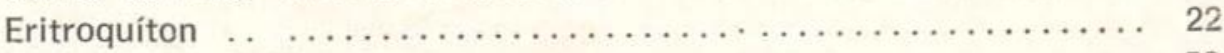

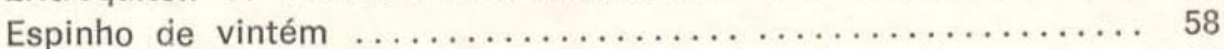

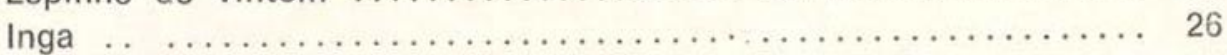

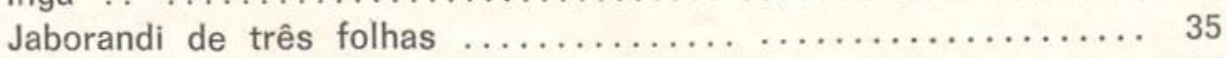

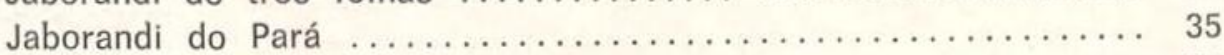

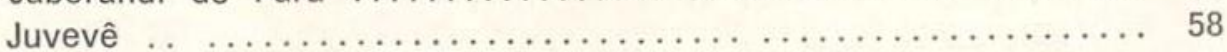

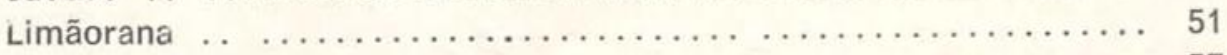

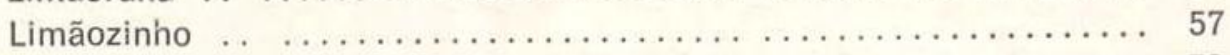

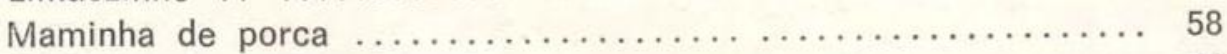

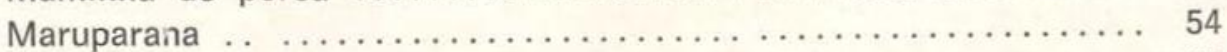

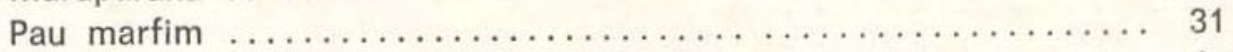

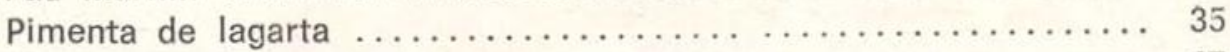

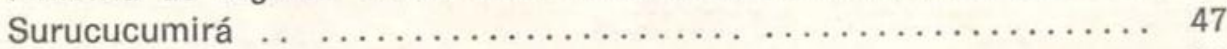

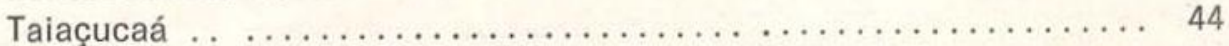

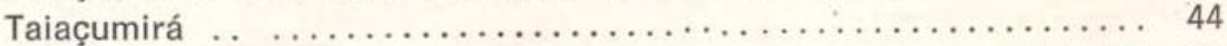

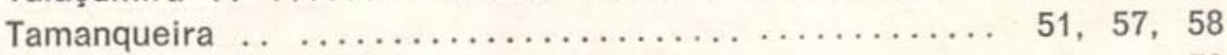

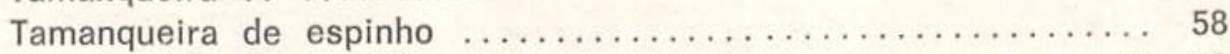

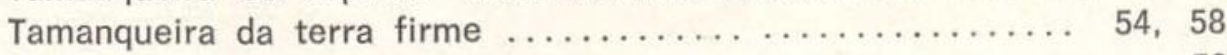

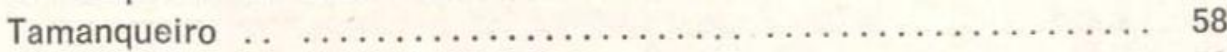

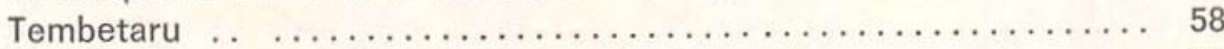

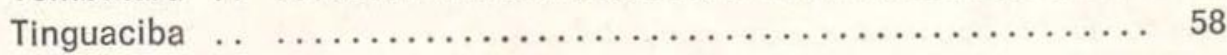




\section{INDICE DAS EXSICATAS}

Os números sublinhados referem-se aos números dos coletores. Quando não existe, segue-se ao nome a sigla e o número do herbário onde se encontra localizada a amostra. $\mathrm{O}$ número entre parêntesis refere-se à página onde está situado cada número de coletor ou de herbário de origem.

Albuquerque, B. W. P. de, 67-49 (52); INPA 5529 (31); IAN 94763 (31).

Albuquerque, B. W. P. de \& Coelho, L., 69-123 (51).

Almeida, J. Chagas de, INPA 339 (57); INPA 734 (38); INPA 2096 (57); INPA 3602 (38); IAN 110856 (38).

Aluizio, J., 126 (54) .

Archer, W. A., 7933 (35); 7945 (57); 8090 (35); 8257 (57) .

Assumpção, S. \& Coelho, D., 36 (29); 78 (29). Aublet, J. B. C. F., s/n, (26) .

Barreto, M., 6095 (22).

Bastos, A. de M., 235 (31).

Black, G. A., 1209 (26); 48-2706 (37).

Black, G. A. \& Ledoux, P., 60-10600 (29).

Boyan, R., 215 (22); 297 (48).

Capucho, P., 498 (57).

Castellanos, A., INPA 27556 (35) .

Cavalcante, P. B., 333 (22); 370 (22); 2608 (35) .

Cava!cante, P. B., 2209 \& Austin, D., 4080 (35)

Cavalcante, P. B. \& Silva, M., 2783 (22).

Coelho, D., INDA 2268 (38); INPA 2953 (13); IAN 110922 (38).

Coelho, L., 7 (19); 45 (33); 48 (15); INPA 1662 (38); INPA 2160 (13); INPA 2223 (13); INPA 3109 (13); MG 26836 (13).

Coelho, L. \& Coelho, D., 38 (35).

Duarte, A. P., 7128 (35).

Duarte, A. P. \& Coelho, L. 9847 (35).

Ducke, A., 62 (13); 99 (40); 445 (31); 455

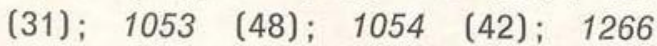
(24); 1798 (33); INPA 12464 (29);
INPA 50602 (29); INPA 50604 (24); MG 474 (57); $M G 8379$ (29); $M G$ 10542 (50); $M G 10579$ (57); $M G$ 10733 (35); $M G 10905$ (51); $M G$ 11490 (57); $M G 12522 \quad$ (29); $M G$ 15702 (47); $M G \quad 15892 \quad$ (22); $R B$ 1295 (13); RB 8567 (47); RB 13613 (47); $R B 13614$ (38); $R B 13617$ (29); $R B \quad 17740 \quad$ (49); $R B \quad 20471 \quad$ (47); $R B$ 20472 (47); $R B 20473$ (13); RB 20473 (38); RB 20483 (48); RB 20490 (54); $R B 20491 \quad(54) ; R B 20493 \quad(54) ; \quad R B$ 20500 (51); $R B 20501$ (51); $R B 20502$ (51); $R B 20503$ (42); RB 23545 (16); $R B 23546 \quad$ (15); $R B 23547$ (13); RB 23550 (40); $R B 23761$ (29); $R B 23766$ (29); $R B 23767$ (30); RB 24166 (43); $\begin{array}{lllll}R B & 24167 \quad \text { (44); } R B \quad 24168 \quad(38) ; R B\end{array}$ 25065 (24); $R B 25472$ (51); $R B 34972$ (19); RB 35595 (52); RB 35596 (26); RB 35597 (38); IAN 43442 (52); IAN 43443 (53); IAN 43450 (26); $R 2324$ (22) .

Egler, W. A. \& Irwin, H. S., 46397 (35).

Egler, W. A., 845 \& Souza, R. (29).

Emmerich, M., 629 \& Andrade, A. G., 666 (35). Ferreira, E., 91-57 (13) .

Forero, E. et al., 6327 (26).

Fróes, R. L., 20734 (38); 22144 (38); 23509 (56); 26103 (26); 26556 (54); 26585 (51); 27916 (29); 28039 (29); 31261 (29); 31715 (54); 33785 (31); 33900 (29); 34849 (38) .

Fróes, R. L. \& Black, G. A., 27338 (35).

Glaziou, A. F. M., 1069 (22).

Guedes, T. N., 85 (40); 316 (57).

Irwin, H. S., 48780 (35).

Irwin, H. S. et al., 47943 (35); 48487 (57).

Kuhlmann, J. G., 325 (35); 488, 489, 490 (35). Ledoux, P., 57-1111 (57).

Lima, D. A., 53-1477 (26) . 
Loureiro, A. A. et al., INPA 35776 (31); INPA 37503 (57); INPA 48001 (13); INPA 48123 (13) .

Maas, P. J. \& Maas, H., 470 (35); 490 (38). Maguire, B., 35118 (18).

Maguire, B., Wurdack, J. J. \& Keith, W. M1., 41780 (37).

Mello, F. C., 14 (51); INPA 2003 (53); INPA 2087 (40); INPA 4122 (38); IAN 94702 (40) .

Mello, F. C. \& Coelho, L., INPA 3492 (38).

Monteiro, O. P. \& Mello, F. C., INPA 50131 (29) .

Oliveira, S., 1864 (35); 2136 (35); 2590 (35); 3005 (35) .

Pena, B. S. \& Silva, A., 58 (38).

Phillipson, W. R. et al., 1459 (35) .

Pires, J. M., 403 (44); 781 (37); 1083 (33); 1117 (15); 3886 (51).

Fires, J. M. \& Black, G. A., 365 (35); 963 (48).

Pires, J. M. \& Westra, L. Y. Th., 48850 (49).

Prance, G. T. et al., 1559 (31); 2247 (38); 2444 (48); 3177 (38); 3181 (13); 3304 (48); 3561 (51); 3786 (53); 4599 (35); 4687 (13); 4979 (38); 5223 (49); 5454 (54); 6651 (49); 7887 (56); 8013 (35); $8359 \quad$ (57); $8460 \quad$ (35); $8899 \quad$ (35); 8978 (49); $9312 \quad$ (22); $10926 \quad$ (22); $11408 \quad$ (53); $13720 \quad$ (35); $14536 \quad$ (35); 14686 (22); 15273 (35); 16464 (48); 16621 (26); 20171 (35); 21785 (35); 22002 (35); 22042 (35); 22487 (35); 23014 (38) .

Prance, G. T., Pennington, T. D. \& Silva, N. T., 1311 (35) .

Ribeiro, B. G. S., 240 (16); 249 (44); 251 (15).
Rodrigues, W. A., 505 (13); 926 (44); 2080 (47); $5424 \quad$ (54); $5463 \quad$ (54); 5468 $\begin{array}{llll}\text { (54); } 6711 \quad \text { (31); } 8146 \quad \text { (31); } 8622 & \end{array}$ (51); 8650 (13); 9000 (55); INPA 7329 (44) .

Rodrigues, W. A. \& Albuquerque, B. W. P. de, 3838 (13); 4241 (57).

Rodrigues, W. A. \& Almeida, J. Chagas de, 2809 (29) .

Rodrigues, W. A. \& Coelho, D., 4144 (13); 4147 (13) .

Rodrigues, W. A. et al., 1977 (13).

Rodrigues, W. A. \& Lima, D. A., 8111 (35).

Rcdrigues, W. A. \& Loureiro, A. A., 5826 (52).

Schultes, R. E. \& Black, G. A., 46-280 (51); 46-364 (33).

Schwacke, C. A. W., 472 (29).

Smith, S. G. \& Idrobo, J. M., 1493 (35).

Silva, A., 83 (57); 83a (57).

Silva, M., 1120 (35).

Silva, M. F. et al., 107 (43); 310 (51); 387 (26); 750 (53); 785 (31); 1753 (35).

Silva, M. F. \& Rodrigues, W. A., 1949 (53).

Silva, N. T., 1518 (35); IAN 117511 (35).

Spruce, R., 1484 (29); 1582 (58); 2006 (29); 2171 (16); 2276 (15); 2596 (33); 2822 (25); 3394 (19)

Ule, E., 5382a. (37); 6141 (35); 6611 (22); 8899 (46).

Williams, L., 12026 (35).

Nomes incompletos:

Baker, 435 (35) .

Freire et al., $R 71433$ (22) .

Schreiner, $R 71277$ (22).

Warszewicz, s/n (24). 


\section{BIBLIOGRAFIA CITADA}

Albuquerque, B.W.P. DE

1970 - Contribuição para o conhecimento das espécies amazônicas do gênero Fagara (Rutaceae). Bol. INPA, Pesq Florestais, $13: 1-22$.

1971 - Nota prévia sobre Rutaceae nova da Amazônia. Acta Amazonica. Manaus, 1(1) : 24 .

1972 - Rutaceae nova da Amazônia. Acta Ama. zonica. Manaus, 2(2): 49-54.

Baillon, H.

1873 - Histoire des Plantes. Paris. $4: 373-511$.

BARTLING, F.G.

1830 - Ordines naturais plantarum. Göttingen. P. $385,386,389,392$.

BeNTHAM, G. \& HoOKER, J.D.

1867 - Genera Plantarum. London. 1: $454 \mathrm{p}$.

BESSEY, C.E.

1915 - The phytogenetic taxonomy of flowering plants. Ann. Mo. Bot Gard. $2: 109-164$.

BRIZICKY, G.K.

1962 - Taxonomic and nomenclatural notes on Zanthoxylum and Glycomis (Rutaceae). Journ. Arnold Arbor. 43: 80-93.

BROWN, R,

1814 - Diosmeae. Flinders' voyage to Terra Australis. London. 2: 533-613.

CANDOlle, A.P. DE

1822 - Mémoire sur les différents espéces, races et varietés de choux et de raiforts de Europe. Mém. Mus. Paris, 9 : 141.

1824 - Aurantiaceae e Rutaceae. Prodromus sistematis naturalis regni vegetabilis. Paris. $1: 748 \mathrm{p}$.

1825 - Terebinthaceae (Tribus Amyrideae et Pteleaceae). Prodromus sistematis naturalis regni vegetabilis. Paris. 2: $644 \mathrm{p}$.

COWAN, R.S.

1967 - Rutaceae of the Guayana Highland

Mem. N. Y. Bot. Gard. 14(3): $: 14$.

COWAN, R.S. \& BRIZICKY, G.K.

1960 - Taxonomic relationship of Diomma Engler ex Harms. Mem. N. Y. Bot. Gard. $10(2): 58-64$.
CRONQUIST, A.

1968 - The evolution and classification of flowering plants. Boston. $396 \mathrm{p}$.

Cuatrecasas, J.

1952 - Notas a la Flora de Colombia. Acad. colomb. Ci., 8(32) : 464-466.

DUCKE, A.

1930 - Plantes nouvelles ou peu connues de la région amazonniene (IVe sér.). Arch. Jard. Bot. Rio de Janeiro, $5:$ 143-144.

1933 - Plantes nouvelles ou peu connues de la région amazonniene (Ve sér.). Arch. Jard. Bot. Rio de Janeiro, $6: 41-43$.

1935 - Plantes nouvelles ou peu coonues de la région amazonniene (7eme sér.). Arch. Inst. Biol. Veg. Rio de Janeiro, $1: 207$.

- Tropical Woods, $43: 21$.

ENDLICHER, S.L.

1840 - Genera plantarum. Vienna. Parte 14, p. 1041-1120; parte 15, p. 1121-1200.

ENGLER, A.

1874 - Rutaceae. In: Martius Flora Brasiliensis. Leipzig. 12(2): 78-196.

1896 - Rutaceae. In: Engler, A. \& Prantl. K., Die natürlichen Pflanzenfamilien, 3(4). 95-201, 357.

1931 - Rutaceae. In: Engler, A. \& Prantl, K., Die natürlichen Pflanzenfamilien, 2. $\mathrm{ed}$., 19a:187-359, 458-459.

Haberlandt, G.

1928 - Physiological Plant Anatomy. (2. ${ }^{\circ}$ ed traduzida por Montagu Drummond). London. $777 \mathrm{p}$.

HALLIER, $\mathrm{H}$

1905 - Provision scheme of the natural (phylo genetic) system of flowering plants. New Physiologist, 4:151-162.

HARTLEy, T.G.

1966 - A revision of the Malesian species of Zanthoxylum (Rutaceae). Journ. Arnold Arbor. $47: 171-221$.

Holmgren, P.K. \& KeUKen, W.

1974 - Index Herbariorum, I. The herbaria of the world. Regnum Vegetabile. 92. Utrecht. 
Hutchinson, J.

1973 - The families of flowering plants. Oxford, Clarendon Press, 3. ${ }^{\circ}$ ed. 968 p. Jussieu, A.H.L. DE

1825 - Rutaceae. Mém. Mus. Hist. Nat. Paris, $12: 384-542$.

JUSSIEU, A.L. DE

1789 - Genera plantatum. Paris, p. 260, 296 e 368.

KUNTH, C.S.

1824 - Terebinthaceorum. Ann. Sci. Nat. Paris, a : 345 .

LAWRENCE, G.H.M.

1971 - Taxonomy of Vascular Plants. New York. 16. ed. $823 \mathrm{p}$.

LECOINTE, $\mathrm{P}$

1947 - Amazônia Brasileira III. Árvores e Plantas Uteis (indígenas ou aclimadas). São Paulo, Comp. Edit. Nacional, 2. ed. sér. 5. ${ }^{\mathrm{a}}$, Brasiliana, $251: 506 \mathrm{p}$.

LINDLEY, J.

1853 - The vegetable kingdom. London. 2. ${ }^{\mathrm{a}}$ ed. $908 \mathrm{p}$.

Loureiro, A.A. \& Silva, M.F.

1968 - Catálogo das Madeiras da Amazônia. Superintendência do Desenvolvimento da Amazônia (SUDAM). 2 : 261-266.
MELCHIOR, H.

1964 - Rutales. In: Syllabus der Pflanzenfamilien. Berlin. 2 : 262-266.

MILANEZ, F.R.

1943 - Anatomia das principais madeiras das Rutáceas Rodriguésia, 7(16) : 5-22.

Nees, E.C.G.D. \& Martius, C.F. Ph. DE 1823 - Fraxinelleae. Nov. Act. Nat. Cur. Breslau, $11: 149$.

Prance, G.T.

1968 - The systematic position of Rhabdodendron Gilg. \& Pilg. Bull. Jard. Bot. Nat. Belg. 38 : 127-146.

RODRIGUES, W.A.

1962 - Árvore hapaxanta na Flora Amazônica. Publ. INPA; Botânica. Manaus, 14:1-8.

Saint-Hilaire, A.F.C.P. DE

1825 - Rutaceae. In: Flora brasilia meridionalis. Paris. $1: 74-94$.

TAKHTAJAN, A.

1969 - Flowering Plants. Origin and dispersal. (Traduzida por C. Jeffrey). Edinburgh. $310 \mathrm{p}$.

WATERMAN, P.G.

1975 - New combinations in Zanthoxylum L. (1753). Taxoa, 24(2/3) : 361-366. 